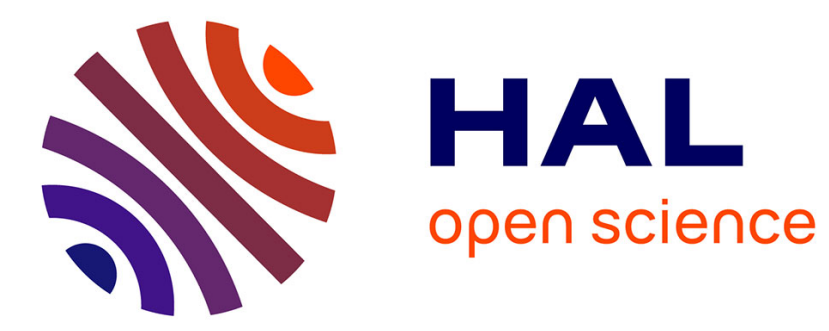

\title{
Mercury speciation in a tropical soil association; Consequence of gold mining on $\mathrm{Hg}$ distribution in French Guiana
}

Stéphane Guedron, Sylvain Grangeon, Bruno Lanson, Michel Grimaldi

\section{To cite this version:}

Stéphane Guedron, Sylvain Grangeon, Bruno Lanson, Michel Grimaldi. Mercury speciation in a tropical soil association; Consequence of gold mining on $\mathrm{Hg}$ distribution in French Guiana. Geoderma, 2009, 153 (issues 3-4), pp.331-346. 10.1016/j.geoderma.2009.08.017 . insu-00424551

HAL Id: insu-00424551

https://hal-insu.archives-ouvertes.fr/insu-00424551

Submitted on 16 Oct 2009

HAL is a multi-disciplinary open access archive for the deposit and dissemination of scientific research documents, whether they are published or not. The documents may come from teaching and research institutions in France or abroad, or from public or private research centers.
L'archive ouverte pluridisciplinaire HAL, est destinée au dépôt et à la diffusion de documents scientifiques de niveau recherche, publiés ou non, émanant des établissements d'enseignement et de recherche français ou étrangers, des laboratoires publics ou privés. 
Mercury speciation in a tropical soil association; Consequence of gold mining on $\mathrm{Hg}$ distribution in French Guiana.

Stéphane GUEDRON ${ }^{\mathrm{a},{ }^{*}}$, Sylvain GRANGEON ${ }^{\mathrm{b}}$, Bruno LANSON $^{\mathrm{b}}$, and Michel GRIMALDI .

${ }^{a}$ Environmental Geochemistry Group - LGIT, Observatory of Earth and Planetary Science (OSUG), University of Grenoble / CNRS - Maison des Géosciences, 1381, rue de la Piscine - Domaine Universitaire - 38400 Saint-Martin-D'Hères, France.

${ }^{\mathrm{b}}$ Mineralogy \& Environments - LGCA, Observatory of Earth and Planetary Science (OSUG), University of Grenoble / CNRS - Maison des Géosciences, 1381, rue de la Piscine - Domaine Universitaire - 38400 Saint-Martin-D'Hères, France.

c UMR Bioemco- Biogéochimie et Ecologie des Milieux Continentaux, UMR211, Institut de Recherche pour le Développement, 32 avenue Henri Varagnat, 93143 Bondy, France.

* Corresponding author - Present address: Institut F.A.-Forel, route de Suisse 10, CP416, 1290 Versoix, Switzerland.

E-mail: stephane.guedron@unige.ch

Tel : +41-223-790-311

Fax : +41-223-790-329 


\section{Abstract.}

Mercury $(\mathrm{Hg})$ speciation was compared in French Guiana pristine soils and in Hg contaminated soils impacted by former ( 1950's) gold-mining activities which used $\mathrm{Hg}$ for gold amalgamation. Four selective extractions were performed on soil samples to assess the fraction of $\mathrm{Hg}$ present as $\mathrm{Hg}(\mathrm{II})$ and bond to organic matter (extracted by $\mathrm{NH}_{4} \mathrm{OH}$ and $\mathrm{KOH}$ ), to amorphous iron oxides (ascorbate) and to soil components other than refractory minerals $\left(\mathrm{HCl} / \mathrm{HNO}_{3}\right)$. In addition, pyrolysis was used to quantify the content of elemental $\mathrm{Hg}$ in contaminated soils. X-ray diffraction $(\mathrm{XRD})$ and $\mathrm{X}$-ray fluorescence micro-mapping $(\mu \mathrm{XRF})$ were used in combination to selective extractions to assess the nature of targeted components, the possible overlaps between the different extraction procedures and the spatial correlation between $\mathrm{Si}, \mathrm{K}, \mathrm{Fe}, \mathrm{Au}$ and $\mathrm{Hg}$.

In soil profiles from pristine toposequences, $\mathrm{Hg}$ concentrations (0.01$0.49 \mu \mathrm{g} \cdot \mathrm{g}^{-1}$ ) decreased with increasing depth in soil matrix. Hg concentrations also decreased from ferralsols to acrisols and further to gleysols. In pristine soil matrix, $\mathrm{Hg}$ was mainly associated to the clay size fraction $(<2 \mu \mathrm{m})$ which was mainly constituted of amorphous and crystalline Fe oxides (Al-substituted goethite and hematite), gibbsite and fine organic matter (OM), whose relative abundances vary along the soil association. Total $\mathrm{Hg}$ concentration was positively correlated with sulfurs and organic carbon suggesting the association of $\mathrm{Hg}$ with $\mathrm{OM}$ sulfur-bearing functional groups. Gleysols were depleted in $\mathrm{Hg}$ because of the prevailing reducing conditions that lead to the dissolution of iron oxides. In the same soil profiles, $\mathrm{Hg}$ concentrations in ferruginous nodules, which make up most of the soil coarse fraction $(>2 \mathrm{~mm})$, were similar to those reported in the pristine soil matrix. These nodules mainly contained Al-substituted hematite and goethite and were especially abundant upslope in 
ferralsols and acrisols. Gold-mined gleysols were strongly disorganized by former activities as neither the original structure nor the texture was preserved. Soil granulometry was dominated by gravels, sands and silts. Hg concentrations (0.09$9.22 \mu \mathrm{g} . \mathrm{g}^{-1}$ ) largely exceeded those in pristine soils. $\mu \mathrm{XRF}$ allowed the identification of Au-amalgamated $\mathrm{Hg}$ and of elemental $\mathrm{Hg}$ droplets. Pyrolysis confirmed $\mathrm{Hg}$ to be mainly present in its elemental form in contaminated soils. Selective extractions showed additional minor contributions of $\mathrm{Hg}(\mathrm{II})$ associated to $\mathrm{OM}$, and to $\mathrm{Al}$ or $\mathrm{Fe}$ oxides.

The combination of selective extractions with XRD and $\mu$ XRF data showed that extraction efficiency is strongly dependent on the soil type, and that this efficiency needs to be determined on a soil-by-soil basis for $\mathrm{Hg}$ speciation studies. $\mathrm{KOH}$ extraction was especially delicate as crystalline and amorphous oxides were extracted together with organic matter.

Key-words: Mercury, Tropical soils, French Guiana, gold-mining, XRD, selective extraction, speciation. 


\section{Introduction}

Tropical soils from the Amazonian basin are known to have accumulated atmospheric $\mathrm{Hg}$ over millions of years, thus inducing geochemical backgrounds higher than those reported in boreal and temperate climate soils (Carmouze et al., 2001). In addition, past and current gold mining activities, which represent the main contribution to anthropogenic emissions (Lacerda, 1997; Roulet et al., 1998; Guedron et al., 2006), contribute to increase further the total $\mathrm{Hg}$ concentrations in these soils. Small-scale mining activities have increased significantly during the worldwide gold rush, created by the gold price increase in the 1980's. UNIDO (United Nations Industrial Development Organization) estimates that in 200410 to 15 million people were working in small-scale gold mines releasing 650-1000 tons of $\mathrm{Hg}$ annually (Veiga and Baker, 2004). In addition to this major atmospheric emission, gold mining activities release large amounts of $\mathrm{Hg}$-rich particles into hydrosystems where methylmercury ( $\mathrm{MMHg}$ ) production has been clearly identified in anoxic and suboxic areas (Benoit et al., 2003; Coquery et al., 2003). In turn, MMHg accumulation along the aquatic food chains is a threat to Amerindian populations whose diet relies mainly on fish (Lebel et al., 1996; Frery et al., 2001; Barbosa et al., 2003). To assess Hg mobility and its availability to methylating microorganisms, it is thus crucial to determine how $\mathrm{Hg}$ is bond to soil particles.

The retention capacity of tropical soils varies as a function of soil components which depends on soil types and horizons (Charlet and Sposito, 1987; Charlet and Sposito, 1989; Fontes and Gomes, 2003). In particular, the relative proportions of soil components responsible for $\mathrm{Hg}$ retention [clay minerals, $\mathrm{Fe}-, \mathrm{Al}-$, and $\mathrm{Mn}$ (oxyhydr)oxides, organic matter] vary with the geochemical conditions which in turn 
depend on the topographic position along the soil association (Boulet et al., 1993; do Valle et al., 2005; Fritsch et al., 2005; Fritsch et al., 2006).

$\mathrm{Hg}$ has a high affinity for soil organic matter, especially for reduced sulfur groups such as thiol ligands (Schuster, 1991; Skyllberg et al., 2000; Khwaja et al., 2006; Skyllberg et al., 2006). High $\mathrm{Hg}$ levels can also be associated to Fe(oxyhydr)oxides. In particular, amorphous or poorly crystalline oxides are known as sinks for metal contaminants owing to their large surface area and/or microporous structure (Trivedi and Axe, 2001). Ferruginous nodules, formed during the lateritic weathering process, also contain elevated Hg contents (Roulet and Lucotte, 1995; Roulet et al., 1998; De Oliveira et al., 2001; Brabo et al., 2003).

Solid-phase chemical speciation has been widely used on sediment samples to decipher metal distribution in contaminated systems (Wallschlager et al., 1998; Rodriguez Martin-Doimeadios et al., 2000; Beldowski and Pempkowiak, 2003; Bloom et al., 2003; Boszke et al., 2006). Most of the recent studies of $\mathrm{Hg}$ speciation in natural or contaminated sediments, soils and tailings used sequential extraction procedure (SEP) or $\mathrm{Hg}$ pyrolysis procedure following published recommendations (Eagenhouse et al., 1978; Di Giulio and Ryan, 1987; Biester and Scholz, 1997; Bloom et al., 2003). While some studies strictly follow the described SEP (Sanchez et al., 2005; Beldowski and Pempkowiak, 2007), many authors adapt it to the studied matrix. Each extraction step of the SEPs for soils and sediments is critical, as it is challenging to obtain an adequate recovery by preventing losses, contamination or speciation changes, and limiting the interferences (Leermakers et al., 2005).

In the present study, the speciation of $\mathrm{Hg}$ among soil components was determined in soil profiles along pristine soil toposequences and in soils contaminated with $\mathrm{Hg}$ by former gold mining in a French Guiana watershed. 
112 Separate selective extractions were used to quantify $\mathrm{Hg}$ distribution between soil carrier phases, in order to avoid cumulative errors intrinsic to SEPs. In addition, the combination of X-ray diffraction (XRD) and chemical analysis allowed the identification of the extracted phases and of possible overlaps between selective extractions (cross recoveries). Intrinsic limitations of the selective extraction procedure are discussed in the light of these results.

\section{Materials and methods.}

\subsection{Research areas}

The former gold mine flat is located in French Guiana (Fig. 1) on the Combat Creek watershed $\left(52^{\circ} 23^{\prime} \mathrm{W}, 4^{\circ} 35^{\prime} \mathrm{N}\right)$, a small catchment of $\sim 1 \mathrm{~km}^{2}$ covered by tropical rain forest. Except for the two hilltops and for the lowland, the relief is characterized by steep slopes (15-30\%). The climate is tropical humid, with an annual average rainfall of $\sim 4000 \mathrm{~mm}$ (Barret, 2004).

The Combat Creek watershed is located on the 'Amina series' of the Guiana Proterozoic shield consisting primarily of darkschist and thin sandstones (Milési et al., 1995). Large gravel deposits from ancient rivers contain large amounts of gold, resulting from the weathering of auriferous quartz veins from the Proterozoic shield (Milési et al., 1995).

Soil distribution within the Combat Creek watershed is typical of French Guiana and is related to soil position along the slopes (Boulet et al., 1979; Grimaldi et al., 2001; Guedron et al., 2006). Ferralsols dominate upslope (Deckers et al., 1998), having typically a high clay $(<2 \mu \mathrm{m}$ size fraction) content and a micro-aggregated structure extending over $1 \mathrm{~m}$ depth, which allows a good vertical water drainage (Guehl, 1984). Ferruginous nodules are present throughout the entire ferralsol 
profiles. Halfway down the slopes, ferralsols steadily evolves to acrisols, a massive alteritic horizon with a high content of fine silts at shallow depth $(<1 \mathrm{~m})$. During rainfalls, a perched aquifer forms on the slope above this massive alteritic horizon. Following rainfalls, the aquifer is evacuated laterally, exporting preferentially clay-size particles and dissolution products (Molicova et al., 1997; Grimaldi et al., 2004). Downslope, the soils become hydromorphic, with dominant sands. A permanent aquifer is present and slowly drained by the river, thus imposing reducing conditions. Whatever the soil type, field observations have shown that quartz, kaolinite, and FeAl-(oxyhydr)oxides dominate mineralogy, quartz being the sole remnant from the primary rock-forming minerals. In the massive alteritic horizon, a few muscovite crystals were also observed. Soil pH ranged from 4.2 to 4.9 . The upper part of the studied watershed (ferralsols and acrisols) was considered to be pristine based on the soil structure and texture.

In the lowland, ancient 'Long Tom' sluices and gold-bearing gravel heaps attest of former gold mining activities dated from the early 1950's. These activities involved the removal of fine particles with water, in order to concentrate heavier gold-rich particles. Soils are thus strongly disorganized, and neither original structure nor texture is preserved. Present day soil granulometry reflects the former activity as gravels, sands and silts are dominant, while the clay-size fraction is almost absent. $\mathrm{Hg}$ droplets were also observed in these gold-mined gleysols during a prospective "panning" campaign. These soils can be described as disorganized gleysols according to their present geochemical characteristics. 


\subsection{Sampling collection and analysis}

\subsubsection{Soil collection}

Three toposequences were sampled in the pristine part of the watershed, (i) the first in the upper part of the basin, (ii) the second on the west (mountain) side and (iii) the third next to the outlet of the basin (Fig. 1). Toposequences II and III reached the gold-mined flats (profiles II-0 and III-0 in Fig. 1).

Thirteen profiles were collected in the former gold-mined flat. SL0 to SL9 profiles were mesh-sampled over a restricted $250 \mathrm{~m}^{2}$ area in the flat zone (Fig. 1). G5 profile was sampled on a gravel heap. Soil profiles were sampled systematically every 10 or $20 \mathrm{~cm}$, down to $1-2 \mathrm{~m}$ depth, using an auger and collected in sterile polyethylene bags.

\subsubsection{Soil conditioning, granulometry and chemical analysis}

Granulometry was determined with standard sieving and sedimentation procedures (Avery and Bascomb, 1974; Rowell, 1994). Identification of the various fractions was performed according to the Udden-Wentworth classification scheme (Wentworth, 1922), and "gravel", "sand", "silt" and "clay" thus refer to particle diameters (x) of $x>2 \mathrm{~mm}, 2 \mathrm{~mm}<\mathrm{x}<50 \mu \mathrm{m}, 50 \mu \mathrm{m}<\mathrm{x}<2 \mu \mathrm{m}$ and $\mathrm{x}<2 \mu \mathrm{m}$, respectively. Total soil organic carbon ([C]), sulfur ([S]), and nitrogen ([N]) concentrations were determined from the dry combustion of soil sample aliquots crushed and sieved to $63 \mu \mathrm{m}$, using a Fisons 1500CHNS auto-analyzer.

Soil samples aliquots used for $\mathrm{Hg}$ analysis, selective extractions and XRD analysis were freeze-dried and sieved to $\mathrm{x}<2 \mathrm{~mm}$. This size fraction was subsequently crushed to $x<63 \mu \mathrm{m}$. Ferruginous nodules were crushed also to $x$ $<63 \mu \mathrm{m}$ and subsequently freeze-dried. Total $\mathrm{Hg}$ concentrations ([HgT]) were 
determined by atomic absorption spectrophotometry after dry mineralization and gold amalgamation with an automatic mercury analyzer (Altec, Model AMA 254). All analyses were duplicated. The relative error was routinely $\pm 5 \%$ and always under $\pm 10 \%$ (Roos-Barraclough et al., 2002). Detection limit (defined as three times the standard deviation (SD) of the blank) is $0.005 \mathrm{\mu g} \mathrm{g}^{-1}$. Concentrations obtained for repeated analyses of certified reference materials (CRMs) never exceeded the published range of concentration $\left(0.090 \pm 0.012 \mu \mathrm{g} \mathrm{g}^{-1}\right.$ and $0.091 \pm 0.008 \mu \mathrm{g} \mathrm{g}^{-1}$ for CRMs 7002, and MESS-3, respectively). Total dissolved $\mathrm{Hg}$ concentration $\left[(\mathrm{HgT})_{\mathrm{D}}\right]$ were analyzed by cold vapor atomic fluorescence spectrometry (CVAFS) after conversion of all mercury species to $\mathrm{Hg}^{0}$ (Bloom and Fitzgerald, 1988), using a Tekran ${ }^{\circledR}$ instrument (Model 2500). Additional information on the method is available elsewhere (Bloom and Fitzgerald, 1988). $(\mathrm{HgT})_{\triangleright}$ concentrations obtained for repeated analyses of CRMs never exceeded the published range of concentration (12.6 $\pm 1.1 \mathrm{ng} \mathrm{L}^{-1}$ for ORMS-3). The detection limit is $0.05 \mathrm{ng} \mathrm{L}^{-1}$ (Bloom and Fitzgerald, 1988).

Dissolved $\mathrm{Fe}$ and $\mathrm{Al}$ were determined by inductively coupled plasma-atomic emission spectrometry (ICP-AES) using a Perkin-Elmer optima 3300DV. Calibration was performed with using standard solutions for Fe and Al (Fluka ${ }^{\circledR} 44903$ for Fe and Fluka ${ }^{\circledR} 06155$ for $\mathrm{Al}$ ). Relative analytical errors were estimated for each sample from triplicate measurements and were lower than $10 \%$.

\subsection{Selective extraction procedure for $\mathrm{Hg}$ and major element analysis}

\subsubsection{Sample selection}

Along soil profiles, samples were selected on the basis of characteristics such as granulometry, $\mathrm{C}$ and/or $\mathrm{Hg}$ contents, reflecting the textural and structural 
variations along soil profiles. In pristine soils, the selection criteria were extreme contents of $\mathrm{C}, \mathrm{Hg}$, clay-size fraction, and fine-silt fraction which increased in alterites. In contaminated gleysols from the gold-mined flat, the selection relied mainly on the abundance of the clay- and sand-size fractions, as well as on $\mathrm{C}$ and $\mathrm{Hg}$ concentrations.

In addition to selected samples, selective extractions were performed for quality assurance/quality controls (QA/QC) on 2 CRMs, namely a light sandy soil (CRM 7002 - Czech Metrological Institute) and a marine sediment (MESS-3 -National Research Council of Canada - Ottawa) and on two natural samples. The latter two samples [acrisol I-1 $(0-10 \mathrm{~cm})$, and contaminated gleysol SL6 $(30-50 \mathrm{~cm})$ ] were chosen as models for the pristine and contaminated parts, respectively, of the watershed. On all samples $[\mathrm{HgT}]$ was measured on both the supernatant and the solid residue to assess extraction recovery. In addition, XRD data was systematically collected on solid residues to identify dissolved mineral species.

\subsubsection{Selective extraction materials and procedure}

Four chemical extractions were chosen to selectively extract the main $\mathrm{Hg}$ carrier phases reported in the literature for tropical soils: organic matter, amorphous Fe oxides, and crystalline Fe/Al oxides.

For a given sample, selective extractions were performed on separate aliquots of dry soil $(\sim 40 \mathrm{mg})$. All analytical procedures were conducted using ultra clean sample handling to avoid laboratory contamination of low-level sample extracts and a cross-contamination of high-level samples (Cossa and Gobeil, 2000). Specifically, all materials in contact with the samples were previously acid washed (1 week in $\mathrm{HNO}_{3}$ $20 \%, 1$ week in $\mathrm{HCl} 10 \%$ ). All solutions were prepared from reagent grade chemicals and supra-pure acids. Selective extractions were performed under a laminar hood in 
$8 \mathrm{ml}$ Teflon ${ }^{\circledR}$ vessels at a 1:100 solid-to-liquid ratio (Bloom et al., 2003). At the end of the extraction time, samples were centrifuged to $3000 \mathrm{rpm}$ for $20 \mathrm{~min}$. The supernatant was analyzed for major elements. The solid residue was rinsed 3 times with $4 \mathrm{~mL}$ MilliQ ${ }^{\circledR}$ water to obtain a final volume of $\sim 16 \mathrm{~mL}$, which was subsequently freeze-dried before $\mathrm{Hg}$ analysis. The $\mathrm{Hg}$ content extracted by a given extraction was calculated as:

$$
[\mathrm{Hg}]_{\text {extracted }}\left(\mathrm{ng} \mathrm{g}^{-1}\right)=\left([\mathrm{HgT}] \times \mathrm{M}_{\text {sample }}-\mathrm{M}_{\mathrm{Hg}} \text { in residue }\right) / M_{\text {sample }}
$$

where $M_{\text {sample }}$ is the mass of the aliquot used (in $\mathrm{g}$ ) and $M_{H g}$ in residue the mass of $\mathrm{Hg}$ measured in the residue (in $\mathrm{ng}$ ).

To extract $\mathrm{Hg}$ bond to fulvic and humic compounds, a sample aliquot was digested in $\mathrm{NH}_{4} \mathrm{OH}$ (1M) for $1 \mathrm{~h}$ (Di Giulio and Ryan, 1987; Rodriguez MartinDoimeadios et al., 2000; Veiga and Baker, 2004). Another extraction focused on organo-chelated $\mathrm{Hg}$ was performed by a $18 \mathrm{~h} \mathrm{KOH}$ digestion (1M) (Bloom et al., 2003). Extraction of $\mathrm{Hg}$ bond to amorphous $\mathrm{Fe}(\mathrm{III})$ oxide minerals and ferrihydrite was performed by adding ascorbate to a sample aliquot and allowing it to react at room temperature for 24h (Kostka and Luther III, 1994). Finally, extraction of $\mathrm{Hg}$ associated to all soil components except refractory minerals (i.e., silicates, primary minerals) was determined after the digestion of soil sample aliquot in a Suprapur $\mathrm{HCl} / \mathrm{HNO}_{3}$ solution (1/9 v/v ratio) for $10 \mathrm{~h}$ at $70^{\circ} \mathrm{C}$ (Coquery et al., 1997; Bloom et al., 2003). All species associated to a specific extractant are labeled as follow: (i)j where i is the element and the subscribe $\mathrm{j}$ describes the extractant (i.e., (i) NH4OH $_{4}$ for $\mathrm{NH}_{4} \mathrm{OH}$, (i) KOH $_{\text {for }} \mathrm{KOH}$, (i) $)_{\mathrm{Asco}}$ for ascorbate and (i) HCl/HNO3 $_{3}$ for $\mathrm{HCl} / \mathrm{HNO}_{3}$ ) and square brackets, [i]], are used for calculated concentrations (1). The concentration of $\mathrm{Hg}$ related to crystalline and refractory minerals $(\mathrm{RC})$ is calculated as the difference between $[\mathrm{HgT}]$ and ascorbate plus $\mathrm{NH}_{4} \mathrm{OH}$ extractions: 
257 This should be equivalent to a complete $\mathrm{HF} / \mathrm{HCl} / \mathrm{HNO}_{3}$ extraction. Similar calculations were made to estimate the fraction of $\mathrm{Hg}$ bond to crystalline $\mathrm{Fe}$ and $\mathrm{Al}$ oxides ([i] $\left.]_{\text {cryst }}\right)$. For this purpose, concentrations obtained after $\mathrm{HCl} / \mathrm{HNO}_{3}$ extraction were considered as related to amorphous and crystalline $\mathrm{Fe}$ and $\mathrm{Al}$ oxides but not to refractory minerals. Thus, $[i]_{\text {cryst }}$ was calculated as the difference between $\mathrm{HCl} / \mathrm{HNO}_{3}$ and ascorbate extraction :

$$
[i]_{\text {Cryst }}\left(\mathrm{mg} \mathrm{g}^{-1}\right)=\left([\mathrm{i}]_{\mathrm{HCl} / \mathrm{HNO} 3} \times \mathrm{M}_{\mathrm{HCl} / \mathrm{HNO} 3}-[\mathrm{i}]_{\text {Asco }} \times \mathrm{M}_{\text {Asco }}\right) / \mathrm{M}_{\text {sample }}
$$

A complementary pyrolysis procedure was used to assess the amount of $\mathrm{Hg}^{0}$ present in the soils (Biester, 1994; Biester and Scholz, 1997; Bollen et al., 2008). After heating a $\sim 1 \mathrm{~g}$ sample aliquot for 48 hours at $180^{\circ} \mathrm{C}$ in a porcelain crucible, the content of $\mathrm{Hg}^{0}$ was determined from the difference in $\mathrm{Hg}$ concentrations between raw and treated samples.

\subsection{Physical methods}

\subsubsection{X-ray diffraction}

X-ray diffraction (XRD) was performed on selected samples [Nodules I-2 (10$20 \mathrm{~cm}), \mathrm{l}-1(30-40 \mathrm{~cm})$ and $\mathrm{I}-1(180-200 \mathrm{~cm})]$ for routine mineralogical identification, but also to identify the minerals targeted by the various selective extractions on CRM 7002, and MESS-3 standards, as well as on samples I-1 $(0-10 \mathrm{~cm})$ and SL6 (30$50 \mathrm{~cm}$ ). For this purpose, XRD patterns were collected on solid residues of the different extractions, and compared to those obtained on the untreated samples.

XRD patterns were recorded on randomly oriented powders using a Bruker D5000 powder diffractometer equipped with a $\mathrm{Si}(\mathrm{Li})$ solid-state detector from Baltic Scientific Instruments and CuKa radiation $(\lambda=1.5418 \AA)$. Intensities were recorded 
280 from 5 to $80^{\circ} 2 \theta$, using $0.04^{\circ} 2 \theta$ steps, and $40 \mathrm{~s}$ counting time per step.

Measurements were duplicated on the CRM 7002 set of samples to ensure sampling homogeneity and selective extraction reproducibility (data not shown).

Mineralogical identification and unit-cell refinement

Basic data processing operations (e.g. background removal, diffractogram normalization) and mineralogical identification, based on peak positions and relative intensities, were performed using the Bruker Diffrac ${ }^{\text {plus }}$ EVA software and the ICDD database.

Relative intensities of XRD lines varied between raw and treated samples as the result of specific mineral dissolutions. To overcome the intensity variations due to the amount of measured sample, all XRD patterns were normalized to a selected quartz peak, as quartz was present in all samples and not dissolved by the reagents used. The peak used for normalization was selected so that (i) there is no peak overlap with other minerals and (ii) that its intensity is statistically meaningful. For iron oxides (hematite and goethite) present in Al-rich environments, experimental peak positions may differ significantly from theoretical ones as the result of isomorphic Alfor-Fe substitutions. In such case, theoretical unit-cell parameters of iron oxides were refined using the U-Fit program (Evain, 1992) to assess their Al-contents.

\subsubsection{Micro X-ray fluorescence mapping and elemental analysis.}

SL6 $(30-50 \mathrm{~cm})$ sample was freeze-dried, sieved to $300 \mu \mathrm{m}$ and used for elemental mapping focused on $\mathrm{Hg}, \mathrm{Au}, \mathrm{Al}, \mathrm{Cl}, \mathrm{Fe}, \mathrm{Cr}, \mathrm{Si}, \mathrm{Ti}, \mathrm{Mn}, \mathrm{Ni}, \mathrm{Ca}$ and $\mathrm{K}$. X-ray fluorescence yields (XRF) were measured with an Eagle III $\mu$-XRF spectrometer (Röntgenanalytik Messtechnik $\mathrm{GmbH}$ ) equipped with a Rh anode and a $40 \mu \mathrm{m}$ polycapillary. XRF was measured for $300 \mathrm{~s}$ per point over a $1.28 \times 1.00 \mathrm{~mm}^{2}$ surface area. The spectrometer was operated under vacuum at $25 \mathrm{kV}$ and $500 \mu \mathrm{A}$ so as to 
maximize the fluorescence yield at the $\mathrm{Hg} \mathrm{L}_{\alpha}$ edge $(9.99 \mathrm{keV})$ while keeping a statistically significant signal on light elements (down to $\mathrm{Al} \mathrm{K}_{\alpha}$ radiation - $1.49 \mathrm{keV}$ ). Further details on the method are given elsewhere (Doering et al., 2004).

\subsection{Statistical treatment.}

Since geochemical data were not normally distributed, the following parameters are reported: mean, standard error on the mean (SEM), median, $25^{\text {th }}$ and $75^{\text {th }}$ percentiles $\left(25^{\text {th }}\right.$ perc. and $75^{\text {th }}$ perc., respectively) and the number of observations (N - Webster, 2001). In addition, non parametric Mann-Whitney rank sum test ( $U$ test) and Kruskal-Wallis one way analysis of variance on ranks ( $H$ test) were used to compare two or more than two data sets, respectively. Pearson correlations were applied to compare multiple data set pairs. Correlation coefficient $(C C)$ and $P$ values $(P)$ are reported.

\section{Results}

\subsection{Blanks and CRMs}

\subsubsection{Mineralogy (QA/QC)}

XRD patterns obtained on treated CRM samples indicate that halite was dissolved by all reagents (Supplementary data - Figs E1b. to E1e. and E2b to E2e). For CRM 7002, the chlorite component was partly dissolved by both $\mathrm{NH}_{4} \mathrm{OH}$ and $\mathrm{KOH}$. Exception made of halite, the effect of ascorbate was negligible. Most of the minerals identified by XRD were thus only affected by $\mathrm{HCl} / \mathrm{HNO}_{3}$ : clinochlore, calcite and dolomite were totally dissolved, and an intensity decrease was observed for hornblende and, to a lesser extent, for kaolinite (Supplementary data - Figs E1e. and E2e.). 


\subsubsection{Extraction recoveries (QA/QC)}

For $\mathrm{NH}_{4} \mathrm{OH}, \mathrm{KOH}$ and $\mathrm{HCl} / \mathrm{HNO}_{3}$ extractions, summation of $\mathrm{M}_{\mathrm{Hg}}$ in both the supernatant and the solid residue led to total $\mathrm{Hg}$ concentration consistent with those of CRM 7002, MESS-3 and I-1 (10-20cm) sample. Relative error was routinely less than $\pm 10 \%$ (Tab. E1). Hg recovery was lower with ascorbate extraction, possibly due to the loss of $\mathrm{Hg}^{0}$ in the supernatant following $\mathrm{Hg}^{\prime \prime}$ reduction (Battke et al., 2008). Consistent with this hypothesis, additional measurements of $\left[(\mathrm{Hg})_{D}\right]$ in the supernatant confirmed a steady decrease with time at the end of the extraction.

\subsection{Pristine soils}

\subsubsection{Granulometry, chemistry and mineralogy}

In the pristine area, the relative proportion of the clay-size fraction $(<2 \mu \mathrm{m})$ decreased from $\sim 90 \%$ in ferralsols to less than $30 \%$ in acrisols and gleysols (Fig. 2). Ferruginous nodules made up most of the abundant gravel size fractions $(x>2 \mathrm{~mm})$ in ferralsols and acrisols, whereas for gleysols vegetal debris prevailed in this size fraction. In the $<2 \mathrm{~mm}$ fraction, total $\mathrm{C}$ and $\mathrm{S}$ contents in superficial horizons decreased from ferralsols and acrisols to gleysols while the $\mathrm{C} / \mathrm{N}$ ratios were similar for all soils, thus indicating an homogeneous mineralization of the fine organic matter (OM - Bravard and Righi, 1991).

Minerals extracted by $\mathrm{HCl} / \mathrm{HNO}_{3}$ in sample $\mathrm{I}-1(0-10 \mathrm{~cm})$ were identified as $\mathrm{Al}-$ substituted iron oxides (goethite and hematite) and gibbsite (Fig. 3). Quartz, anatase, kaolinite, and muscovite being essentially unaffected by the $\mathrm{HCl} / \mathrm{HNO}_{3}$ extraction (Supplementary data - Fig. E3e.).

For $\mathrm{HCl} / \mathrm{HNO}_{3}$ and ascorbate extractions, $\mathrm{Fe}$ and $\mathrm{Al}$ concentrations were correlated to the content of the clay size fraction (Tab. 1) showing that crystalline and 
amorphous $\mathrm{Fe}$ and $\mathrm{Al}$ oxides were central in this fine fraction. Large $\mathrm{Al}$ and $\mathrm{Fe}$ concentrations were measured in supernatants following $\mathrm{KOH}$, ascorbate and $\mathrm{NH}_{4} \mathrm{OH}$ extractions. XRD confirmed that no crystalline Fe or Al oxides were dissolved by $\mathrm{NH}_{4} \mathrm{OH}$, thus supporting the dissolution of amorphous (or poorly crystalline) $\mathrm{Fe}$ and/or Al minerals. In addition, goethite was partially dissolved by ascorbate and hematite by $\mathrm{KOH}$, as indicated by the $\sim 10-20 \%$ intensity decrease of their characteristic XRD lines after these chemical extractions (Fig. 3). For all pristine soil samples, partial dissolution of these well-crystallized species is supported by the higher $\mathrm{Al}$ and $\mathrm{Fe}$ concentrations measured in $\mathrm{KOH}$ (median $=52.6 \%$ and $12.1 \%$ of $[\mathrm{Al}]_{\mathrm{HC} / \mathrm{HNO}}$ and $\left.[\mathrm{Fe}]_{\mathrm{HC} / \mathrm{HNO}}\right)$ and ascorbate (median $=24.7 \%$ and $21.7 \%$ of $[\mathrm{Al}]_{\mathrm{HCl} / \mathrm{HNO}}$ and $[\mathrm{Fe}]_{\mathrm{HClHNO}}$ ) extracts compared to $\mathrm{NH}_{4} \mathrm{OH}$ extracts (median=9.1\% and $3.6 \%$ of $[\mathrm{Al}]_{\mathrm{HC} / \mathrm{HNO} 3}$ and $\left.[\mathrm{Fe}]_{\mathrm{HCl} / \mathrm{HNO}}\right)(H$ test, $\mathrm{P}<0.001)$.

$[\mathrm{Fe}]_{\mathrm{HCl} / \mathrm{HNO}},[\mathrm{Al}]_{\mathrm{HCl} / \mathrm{HNO}},[\mathrm{Fe}]_{\mathrm{Asco}}$ and $[\mathrm{Al}]_{\mathrm{Asco}}$ decreased steadily along the slopes from ferralsols to gleysols (Fig. 4), $[\mathrm{Fe}]_{\mathrm{Asco}}$ and $[\mathrm{Al}]_{\mathrm{Asco}}$ being commonly lower than $[\mathrm{Fe}]_{\text {Cryst }}$ and $[\mathrm{Al}]_{\text {cryst }}$ for all profiles (Fig. 4). In ferralsols and acrisols, amorphous $\mathrm{Fe}$ and $\mathrm{Al}$ oxides were most abundant in the A horizon and in the top $50 \mathrm{~cm}$ of the $B$ horizon, where weathering was most intense and granulometry dominated by clays. In the C horizon, the relative proportion of amorphous oxides decreased while well crystallized oxides and residual primary minerals became predominant, more especially in the fine silt size fraction. Al-for-Fe substitutions were identified in goethite ( $\sim 33$ Al mol\%) and hematite ( 10 Al mol\%) from XRD unit-cell determinations and confirmed by the positive correlations between $[\mathrm{Fe}]_{\text {cryst }}$ and $[\mathrm{Al}]_{\text {Cryst }}$ in $\mathrm{B}$ and $\mathrm{C}$ horizons (Fig. $4-\mathrm{CC}=0.76 ; \mathrm{P}<0.01$ ). Similar correlation was observed between $[\mathrm{Fe}]_{\mathrm{Asco}}$ and $[\mathrm{Al}]_{\mathrm{Asco}}(\mathrm{CC}=0.98 ; \mathrm{P}<0.01)$ for the whole profiles of pristine soils. The better correlation found between $[\mathrm{Fe}]$ and $[\mathrm{Al}]$ for ascorbate than 
377 for crystalline oxide is suggestively due to an increase in [AI] related to Al extraction from gibbsite and in a lesser extent from kaolinite during $\mathrm{HCl} / \mathrm{HNO}_{3}$ extraction.

\subsubsection{Hg in pristine soils}

Total mercury concentrations measured in pristine soils matrix (0.01$0.49 \mu \mathrm{g} \cdot \mathrm{g}^{-1}$ - Fig. 2) were consistent with those recently reported for French Guiana soils (0.09-0.50 $\mu \mathrm{g} \cdot \mathrm{g}^{-1}$ - Richard et al., 2000; Grimaldi et al., 2001; Guedron et al., 2006), the highest concentrations being measured in ferralsols. [HgT] decreased along the slope in acrisols and in gleysols (Fig. 2).

$[\mathrm{HgT}]$ were positively correlated with $[\mathrm{Hg}]$ extracted by $\mathrm{HCl} / \mathrm{HNO}_{3}, \mathrm{KOH}$, $\mathrm{NH}_{4} \mathrm{OH}$ and ascorbate (Tab. 1). In turn, $[\mathrm{Hg}]$ extracted by the four reagents were positively correlated to the content of the clay-size fraction, [S] and [C]. The clay-size fraction, which is composed of $\mathrm{OM}$ (S-groups) and $\mathrm{Fe}$ and $\mathrm{Al}$ minerals, thus represents the main $\mathrm{Hg}$ reservoir (Tab. 1).

In general, $[\mathrm{Hg}]$ extracted by all four reagents decreased with depth and from ferralsols to gleysols. However, Figure 5 shows that $\mathrm{Hg}$ extraction yields can be separated in two sets: (i) ferralsols and superficial acrisols and (ii) deep acrisol alteritic (C) horizons and gleysols. In both sets, $\mathrm{NH}_{4} \mathrm{OH}$ extraction yields were significantly larger than ascorbate ones but followed the same trend. $(\mathrm{Hg})_{\mathrm{NH} 4 \mathrm{OH}}$ and $(\mathrm{Hg})_{\text {Asco }}$ extraction yields were highest in superficial horizons of both ferralsols and acrisols and steadily decreased with depth. Only in the upstream profiles I-1 and I-2 $(\mathrm{Hg})_{\mathrm{NH} 4 \mathrm{OH}}$ and $(\mathrm{Hg})_{\mathrm{Asco}}$ extraction yields were constant with depth. In gleysols and deep alteritic horizons of acrisols, both $(\mathrm{Hg})_{\mathrm{NH} 4 \mathrm{OH}}$ and $(\mathrm{Hg})_{\mathrm{Asco}}$ decreased rapidly with depth, whereas $(\mathrm{Hg})_{\mathrm{RC}}$ extraction yields increased strongly with increasing depth. $(\mathrm{Hg})_{\mathrm{RC}}$ decreased with increasing depth in the B horizons of ferralsols and acrisols, then increasing steadily in the ferralsol $\mathrm{C}$ horizons. $(\mathrm{Hg})_{\mathrm{KOH}}$ extraction yields were 
highly variable with highest values in ferralsol and acrisol B horizons. In pristine gleysols (profile II-1), $(\mathrm{Hg})_{\mathrm{Kон}}$ extraction yields increased with increasing depth over the first $50 \mathrm{~cm}$, while decreasing in the $\mathrm{C}$ horizon.

\subsection{Ferruginous nodules in pristine soils}

\subsubsection{Chemistry and mineralogy}

Ferruginous nodules $(>2 \mathrm{~mm}$ ) were abundant (mean $\pm R S D=45.8 \pm 28.6 \%$ total weight), especially in superficial horizons of the pristine toposequences, their relative abundance decreasing from ferralsols to gleysols. Nodules from samples I-2 $(10-20 \mathrm{~cm}), \mathrm{I}-2(30-40 \mathrm{~cm})$ and $\mathrm{I}-2(180-200 \mathrm{~cm})$ contained quartz, Al-substituted hematite and goethite, gibbsite and kaolinite. Figure 6 shows the steady increase of muscovite $(\mathrm{Mu})$, paragonite $(\mathrm{Pa})$, gibbsite $(\mathrm{Gb})$ and rutile $(\mathrm{Ru})$ contents from surface (sample I-2, 10-20 cm) to depth (sample I-2, 180-200 cm - Fig E4). This mineralogical evolution is consistent with chemical data as $[\mathrm{Fe}]_{\mathrm{HCl} / \mathrm{HNO}}$ and $[\mathrm{Al}]_{\mathrm{HC} / \mathrm{HNO}}$ steadily decreased with increasing depth.

Position of the iron oxide peaks (goethite and hematite) shifted to lower angular values with increasing depth (Fig. 6, inset), thus indicating the lengthening of unit-cell parameters, and thus the probable decrease of Al-for-Fe substitution, since the ionic radius of $\mathrm{Al}$ is smaller than Fe (Shannon, 1976). The extent of this substitution was assessed for the two oxides by refinement of the unit-cell parameters and empirical relations between the Al content and the lattice parameters (Schulze, 1984; Stanjek and Schwertmann, 1992). Al substitutions in hematite decreased from $17 \mathrm{~mol} \%$ (surface) to $10 \mathrm{~mol} \%$ (deep alteritic horizons) and were almost constant ( $20 \mathrm{~mol} \%)$ over the entire profile for goethite. Uncertainty on lattice parameters (and therefore on Al substitution quantification) was low for hematite 
owing to the sharp and numerous diffraction peaks, but higher for goethite. Indeed, few isolated diffraction peaks were available for the determination of the unit-cell parameters and peaks were broadened.

The intensity of hematite diffraction lines increased with decreasing depth, thus indicative of a higher proportion of hematite towards the surface, consistent with its status of final alteration product of iron-rich phases (Schwertmann and Latham, 1986). Hematite and goethite are indeed the most thermodynamic stable iron oxides in surface conditions. Amorphous oxides were present as minor constituents since $\mathrm{Al}$ and Fe extracted by ascorbate and $\mathrm{NH}_{4} \mathrm{OH}$ never exceeded $7 \%$ of their $\mathrm{HCl} / \mathrm{HNO}_{3}$ counterparts (Fig. E5). As in pristine soils matrix, $\mathrm{KOH}$ extraction likely induced the partial dissolution of gibbsite as $[\mathrm{Al}]_{\mathrm{KOH}}$ was large (median $=51.5 \%$ of $\left.[\mathrm{Al}]_{\mathrm{HCl} / \mathrm{HNO}}\right)$.

\subsubsection{Hg in ferruginous nodules of pristine soils}

For surface horizons, $[\mathrm{HgT}]$ were much lower in nodules than in the soil matrix. $[\mathrm{HgT}]$ increased with increasing depth, similar values being obtained for nodules and soil matrix in the deepest sample of acrisol $\mathrm{I}-1$ profile. $[\mathrm{HgT}]$ were even larger in nodules than in soil matrix for ferralsol I-2 samples below $50 \mathrm{~cm}$ depth (Fig. E5).

$[\mathrm{HgT}]$ was positively correlated with $[\mathrm{Hg}]_{\mathrm{HC} / \mathrm{HNO}}$ and $[\mathrm{Hg}]_{\mathrm{KOH}}(\mathrm{P}<0.05)$ and with $[\mathrm{Fe}]_{\mathrm{HCl} / \mathrm{HNO} 3}$ and $[\mathrm{Al}]_{\mathrm{HCl} / \mathrm{HNO} 3}(\mathrm{P}<0.05) .(\mathrm{Hg})_{\mathrm{HCl} / \mathrm{HNO}}$ extraction yields were larger in ferralsol nodules from deep horizons compared to surface ones. Conversely, in acrisols they were larger for surface horizons. For all nodules these yields scattered about $80 \% .(\mathrm{Hg})_{\mathrm{Asco}}$ and $(\mathrm{Hg})_{\mathrm{NH} 4 \mathrm{OH}}$ extraction yields rarely exceeded $10 \%$ and rapidly decreased with increasing depth in both acrisols and ferralsols. $(\mathrm{Hg})_{\mathrm{KOH}}(44.8$ $\pm 30.2 \%)$ extractions yields were systematically larger than the sum $(\mathrm{Hg})_{\text {Asco }}+$ $(\mathrm{Hg})_{\mathrm{NH} 4 \mathrm{OH}}$, and progressively decreased downwards in $\mathrm{I}-1$ and $\mathrm{I}-2$ profiles. 


\subsection{Contaminated gold-mined soils}

\subsubsection{Granulometry, mineralogy and chemistry}

In the gold-mined flat, contaminated gleysols contained a large proportion of gravel size fractions (mainly quartz gravels and stones, mean \pm RSD $=42.7 \pm 24.6 \%$ total weight) and the $<2 \mathrm{~mm}$ fraction was dominated by sands in contrast with pristine soils (Fig. 2b). Total organic C largely exceeded the concentrations determined in pristine soils and elevated $\mathrm{C} / \mathrm{N}$ ratios were characteristic of poorly mineralized OM (data not shown). Leaves and wood debris were visible in the litter.

Minerals present in sample SL6 after $\mathrm{HCl} / \mathrm{HNO}_{3}$ extraction were quartz, kaolinite, muscovite, diaspore, rutile and microcline. Gibbsite was for the most part dissolved by $\mathrm{HCl} / \mathrm{HNO}_{3}$, which also possibly partially dissolved kaolinite. The absence of Fe oxides is consistent with the low $[\mathrm{Fe}]_{\mathrm{HCl} / \mathrm{HNO} 3}$ values $\left(0.35 \mathrm{mg} \cdot \mathrm{g}^{-1}\right)$.

Amorphous and crystalline $\mathrm{Fe}$ and $\mathrm{Al}$ oxides were scarce in contaminated soils as shown by the low $\mathrm{Al}$ and $\mathrm{Fe}$ concentrations extracted by any reagent compared to pristine soils. For all soil profiles, $[\mathrm{Al}]_{\mathrm{HCl} / \mathrm{HNO} 3}$ and $[\mathrm{Fe}]_{\mathrm{HC} / \mathrm{HNO} 3}$ were maximum in surface horizons, and sharply decreased to $\sim 5 \mathrm{mg}^{-1} \mathrm{~g}^{-1}$ at $\sim 40 \mathrm{~cm}$ depth, except for II0, SL0 and G5 profiles.

As for pristine soils, partial gibbsite dissolution by $\mathrm{KOH}$ was evidenced by chemistry data as $[\mathrm{Al}]_{\mathrm{KOH}}\left(\right.$ median $=76.3 \%$ of $\left.[\mathrm{Al}]_{\mathrm{HClHNO}}\right)$ were larger than $[\mathrm{Al}]_{\mathrm{Asco}}$ $\left(\right.$ median $=55.7 \%$ of $\left.[\mathrm{All}]_{\mathrm{HCl} / \mathrm{HNO} 3}\right)$ and $[\mathrm{Al}]_{\mathrm{NH} 4 \mathrm{OH}}\left(\right.$ median $=28.5 \%$ of $\left.[\mathrm{Al}]_{\mathrm{HCl} / \mathrm{HNO} 3}\right)(U$ test, $P<0.05)$. Fe oxides were also more attacked by ascorbate $\left([\mathrm{Fe}]_{\text {Asco }}\right.$ median $=31.1 \%$ of $\left.[\mathrm{Fe}]_{\mathrm{HC} / \mathrm{HNO}}\right)$ than by $\mathrm{KOH}$ and $\mathrm{NH}_{4} \mathrm{OH}\left([\mathrm{Fe}]_{\mathrm{KOH}}\right.$ : median $=17.3 \%$ of $[\mathrm{Fe}]_{\mathrm{HC} / \mathrm{HNO}}$ and $[\mathrm{Fe}]_{\mathrm{NH} 4 \mathrm{OH}}:$ median $=14.8 \%$ of $\left.[\mathrm{Fe}]_{\mathrm{HCl} / \mathrm{HNO} 3}\right)$. 


\subsubsection{Hg in contaminated gold mined soils}

$[\mathrm{HgT}]$ values measured in gleysols from the gold-mined flat (up to $\sim 10 \mu \mathrm{g} \cdot \mathrm{g}^{-1}$ in SL6 profile) were up to 5 times higher than those determined in gleysols from the pristine area (Fig. 2b). Although extremely variable, even over very short distances, these values were consistent with those determined in $\mathrm{Hg}$-contaminated soils from different gold-mining regions (Lechler et al., 1997; Lechler et al., 2000; Richard et al., 2000; Sladek and Gustin, 2003), and positively correlated with [Hg] extracted by all four reagents (Tab. 2a and 2b). Contrarily to the pristine area, where gleysols were the pole of lowest $[\mathrm{HgT}]$, the only significant correlation of $[\mathrm{HgT}]$ with other soil parameters was observed with the sand-size fraction $(P<0.05)$.

$\mu$-XRF map (Fig. 7) shows that $\mathrm{Hg}$ was not homogeneously distributed in sample SL6 $(30-50 \mathrm{~cm})$. Indeed, $\mathrm{Hg}$ is essentially present as "hot-spots" of 30 to $100 \mu \mathrm{m}$ in diameter. In these hot-spots, $\mathrm{Hg}$ concentration is not correlated with any element (data not shown), except for a covariation with Au (Fig. 7). These spots are thus likely $\mathrm{Hg}^{0}$ droplets, possibly amalgamated with Au. Consistently, pyrolysis measurements showed that almost $60 \%$ of total $\mathrm{Hg}$ was desorbed at $180^{\circ} \mathrm{C}$. However, lower percentages of desorbed $\mathrm{Hg}$ were determined for SL8 and SL7 samples, thus suggesting that $\mathrm{Hg}^{0}$ was not systematically the main $\mathrm{Hg}$ form over the entire former gold-mined flat (Fig. 8). Consistently, selective extractions have shown that $\mathrm{Hg}$ was partially associated to $\mathrm{OM}$ and amorphous oxides for some samples as shown by the $\mathrm{NH}_{4} \mathrm{OH}$ and ascorbate extraction yields. Such associations remained however minor as $(\mathrm{Hg})_{\mathrm{NH} 4 \mathrm{OH}}($ median $=28.4 \%)$ and $(\mathrm{Hg})_{\mathrm{Asco}}(\operatorname{median}=14.7 \%)$ extraction yields only seldom exceeded 50 and $30 \%$, respectively (Fig. 8). Relative proportion of $\mathrm{Hg}$ associated to refractory minerals was negligible as $(\mathrm{Hg})_{\mathrm{HClHNO} 3}$ extraction yields were systematically $\sim 100 \%$. In this case, large $(\mathrm{Hg})_{\mathrm{RC}}$ reflect the 
proportion related to $\mathrm{Hg}^{0}$ (Fig.8). $\mathrm{KOH}$ extraction yields also were high (median = $86.5 \%$ ), being always higher than $80 \%$ in the uppermost $40 \mathrm{~cm}$.

\section{Discussion}

\subsection{Selective extractions}

Further investigation was performed to unravel the reactions leading to $\mathrm{Hg}$ reduction and loss during ascorbate extraction, although $[\mathrm{Hg}]_{\text {Asco }}$ were not biased, being calculated from the analysis of the solid residue. Results of the pyrolysis procedure were also questionable as the pyrolysis $\left(180^{\circ} \mathrm{C}\right)$ of marine sediment MESS-3 has shown no significant desorption of $\mathrm{Hg}$, while almost $70 \%$ of total $\mathrm{Hg}$ desorbed from light sandy soil CRM 7002 under the same conditions. It is thus likely that in addition to $\mathrm{Hg}^{0}, \mathrm{Hg}$ bond to $\mathrm{OM}$ was partially desorbed during pyrolysis. Pyrolysis temperature $\left(180^{\circ} \mathrm{C}\right)$ was indeed close to the temperature range reported by Biester and Scholz (1997) for the thermal release of $\mathrm{Hg}$ bound to organic compounds $\left(200-350^{\circ} \mathrm{C}\right)$. This is especially relevant for the assessment of the different $\mathrm{Hg}$-compartments in organic-rich contaminated soils.

Cross recoveries between selective extractions were observed for both CRMs and natural samples, but it was also possible to attribute selective mineral extractions to each reagent. The selective character of a given extraction depends on the considered soil matrix, as reagent selectivity depends both on the nature of components present and on their reactivity with respect to a given reagent. Overlapping extractions further increase the uncertainty on the relative proportion of $\mathrm{Hg}$ associated to any carrier phase. Although chemical data may help to assess cross recoveries, the restricted and variable selectivity of the different reagents precludes the use of selective extractions as standardized procedures for 
environmental studies. Specifically, the use of selective extractions needs preliminary investigation to assess reagent selectivity for a given soil matrix.

\subsection{Hg distribution in pristine soils}

The study of $\mathrm{Hg}$ distribution in a soil has to take into account the original soil cover formation, its current evolution and its present topographic position, that is its position in the soil association (Fritsch et al., 2006). These factors are indeed responsible, at least partially, for the relative abundance and the reactivity of soil organic and mineral components, including $\mathrm{Hg}$ carriers, thus providing additional insight in the $\mathrm{Hg}$ natural equilibrium and contents.

\subsubsection{Hg carrier phases in soil profiles}

A positive correlation between the relative amount of the clay-size fraction and $\mathrm{C}, \mathrm{S},[\mathrm{Fe}]$ and $[\mathrm{Al}]$ extracted by $\mathrm{HCl} / \mathrm{HNO}_{3}, \mathrm{NH}_{4} \mathrm{OH}$ and ascorbate is shown in Table 2. $\mathrm{Hg}$ is thus likely associated with finely divided $\mathrm{Fe}$ and $\mathrm{Al}$ organic complexes and/or with organic coatings on Fe/Al oxides. Several authors have already shown that in Amazonian micro-aggregated horizons, micropeds develop from the bonding between clays, organic matter and iron oxides through the formation of carboncoatings on mineral surfaces (Tandy et al., 1990; Malengreau and Sposito, 1997; Do Nascimento et al., 2004).

Specific bonding of $\mathrm{Hg}$ with sulfur groups from finely divided organic matter may be inferred from the above described correlations for all pristine soils. This is consistent with previous reports of organics, and more especially of reduced sulfur groups, being the most effective sorbents for $\mathrm{Hg}$ in acidic environments $(\mathrm{pH}<\sim 4.5$ 5.0), compared to iron oxides and clay minerals (Andersson, 1979; Schuster, 1991; Roulet and Lucotte, 1995; Skyllberg et al., 2000; Skyllberg et al., 2006; Manceau and 
Nagy, 2008).

In addition to this essential organic contribution, $\mathrm{Hg}$ contents in soils from French Guiana are also controlled by the actual nature of $\mathrm{Fe}$ and $\mathrm{Al}$ (oxyhydr)oxides (Roulet and Lucotte, 1995; Roulet et al., 1998). In pristine soil matrix, large [Hg] $]_{\text {Asco }}$ and $[\mathrm{Hg}]_{\mathrm{HC} / \mathrm{HNO}}$ values were indeed attributed to Al-substituted amorphous and crystalline Fe oxides. As a result of their larger surface areas compared to their crystalline counterparts, amorphous or poorly crystalline species have an increased adsorption capacity, (Schwertmann and Latham, 1986; Schwertmann and Cornell, 2000). The positive correlation between $[\mathrm{Hg}]_{\mathrm{KOH}}$ and $[\mathrm{Al}]_{\mathrm{KOH}}$ supports also the importance of $\mathrm{Al}$ oxides as a reservoir for $\mathrm{Hg}$. This reservoir is accessible through $\mathrm{KOH}$ and, to a lesser extent, through ascorbate extractions, thus the large $[\mathrm{Al}]_{\mathrm{Asco}}$ plead for the partial dissolution of (amorphous) Al (oxyhydr)oxides (Schwertmann and Latham, 1986).

In nodules, as in soil matrix, $\mathrm{Hg}$ is bond to $\mathrm{Al}$ and Fe oxides. Ferruginous nodules are abundant in ferralsols and acrisols, where they represent $\sim 50 \%$ of total soil materials and thus represent large $\mathrm{Hg}$ reservoirs, $[\mathrm{HgT}]$ being similar in nodules and soil matrix. In addition to Al-substituted hematite and goethite, gibbsite contributes significantly to $\mathrm{Hg}$ retention in soil nodules, especially in surface horizons, as suggested by the large $(\mathrm{Hg})_{\mathrm{KOH}}$ extraction yields associated with large $[\mathrm{Al}]_{\mathrm{KOH}}$ values. This observation is consistent with the strong affinity of $\mathrm{Hg}(\mathrm{II})$ for gibbsite (Kim et al., 2004a; Kim et al., 2004b; Weerasooriya et al., 2007).

Finally, the contribution of refractory minerals (identified as muscovite, anatase, rutile and kaolinite) is non negligible, although minor, in pristine soils as the median $(\mathrm{Hg})_{\mathrm{HCl} / \mathrm{HNO} 3}$ extraction yield is only $89.8 \%$. 


\subsubsection{Influence of soil structure on Hg distribution in soil profiles}

From the above description, it appears that the vertical distribution of $\mathrm{OM}$, $\mathrm{Al} / \mathrm{Fe}$ (oxyhydr)oxides and ferruginous nodules in the soil matrix rules $\mathrm{Hg}$ distribution. In the following section, pedological and chemical characteristics responsible for the spatial distribution of these components in soil profiles will be discussed.

Upslope, large $[\mathrm{HgT}]$ have been measured in the matrix of the ferralsol microaggregated horizons (i.e., A and B horizons). The micro-aggregated structure confers a good water drainage capacity to ferralsols, favoring water flow and oxidizing conditions. As a result, $\mathrm{Hg}$ is spread throughout these micro-aggregated horizons as the result of both significant leaching and migration of atmospheric inputs (Guedron et al., 2006). Plant litter is rapidly mineralized in surface horizons, and the rapid turnover of humic substances leads to the migration of fulvic acids in deeper organomineral horizons where they are complexed to Fe and Al oxides (Roulet and Lucotte, 1995). Thus, Hg originating from plant litter decomposition and/or from atmospheric fallouts can migrate into the organo-mineral horizons as organic- $\mathrm{Hg}$ complexes and progressively adsorb onto $\mathrm{Al} / \mathrm{Fe}$ (oxyhydr)oxides. Soil ecosystem engineers (soil invertebrates and roots) also play an important role in the particulate transfer of $\mathrm{Hg}$ by enhancing aggregation (Velasquez et al., 2007) and soil hydraulic conductivity (Grimaldi et al., 2008) through biogenic soil organization. In the micro-aggregated B horizon of ferralsols, the distribution of amorphous Fe oxides is positively correlated to $[\mathrm{HgT}]$, although their relative abundance is lower than or similar to that of the crystalline varieties. The comparison of $[\mathrm{Fe}]_{\mathrm{Cryst}}$ and $[\mathrm{Fe}]_{\mathrm{Asco}}$ indicates that the relative proportion of crystalline Fe oxides is increased further in the superficial layer and in the deep alteritic horizons compared to the micro-aggregated B horizon of ferralsols. In addition, the positive correlations between $[\mathrm{Hg}]_{\mathrm{RC}}$ and $[\mathrm{Fe}]_{\mathrm{Cryst}}$ or $[\mathrm{Al}]_{\mathrm{Cryst}}$ 
throughout the entire soil profile suggest that $[\mathrm{Hg}]_{\mathrm{RC}}$ is partially associated to Alsubstituted crystalline $\mathrm{Fe}$ oxides. In this case, the sum of $[\mathrm{Hg}]$ adsorbed onto amorphous and crystalline Fe oxides would be comparable or larger than the part related to organic compounds.

The micro-aggregated structure of ferralsols disappears progressively with increasing depth, giving rise to deep mineral horizons with a continuous structure composed of large mineral relics. Parental material relics "dilute" Al/Fe oxides and thus reduce the overall sorption capacity of deep horizons. Another essential factor is the lower permeability of deep horizons which limits the downward migration of $\mathrm{Hg}$ (Guedron et al., 2006). Hg content thus mainly results from rock weathering and pedogenesis (Guedron et al., 2006), [HgT] being mainly associated with coarsegrained goethite and hematite.

In ferralsol nodules, $\mathrm{Hg}$ is mainly bond to Al-substituted hematite and goethite, and to gibbsite. As in ferralsol matrix, highest $[\mathrm{HgT}]$ values were measured in the micro-aggregated horizon. Indeed, the downward decrease of $(\mathrm{Hg})_{\mathrm{HC} / \mathrm{HNO} 3}$ extraction yields and the mineralogical evolution suggest that $A$ and $B$ horizons nodules are primarily composed of neo-formed minerals, thus indicating an advanced stage of pedogenesis and weathering in superficial horizons. Mineral neoformation also appears to favor the incorporation of atmospheric $\mathrm{Hg}$ inputs.

Halfway down the slope, in acrisols, a similar mineralogical and structural contrast is observed between superficial (A and B horizons) and alteritic horizons. This transition is sharp as evidenced by the increase of the silt fraction and by the decrease of $[\mathrm{HgT}]$. As for ferralsol, the increase of refractory minerals with increasing depth is most likely responsible for the observed decrease of $[\mathrm{HgT}]$. 
Downslope, in gleysols, $[\mathrm{HgT}]$ were lower since fine organic fraction, $\mathrm{S}$ and amorphous oxides are less abundant than upslope, even though carrier phases were similar to those identified in ferralsols and acrisols. Gleysols are depleted in iron oxides and the main minerals are kaolinite, gibbsite, muscovite and quartz. $\mathrm{Hg}$ extracted by $\mathrm{NH}_{4} \mathrm{OH}$ never exceeds $40 \%$ of $[\mathrm{HgT}]$ in gleysol surface horizons and rapidly decreases with depth. $\mathrm{Hg}$ bond to amorphous oxides never exceeds $20 \%$ of [HgT], and almost $50 \%$ of $[\mathrm{HgT}]$ is likely associated to Al-substituted crystalline $\mathrm{Fe}$ oxides, gibbsite and to refractory minerals. Consistently, $\mathrm{Hg}, \mathrm{Fe}$, and $\mathrm{Al}$ extracted by $\mathrm{HCl} / \mathrm{HNO}_{3}$ are together positively correlated in the gleysol profile. In depth, $\mathrm{Hg}$ is less abundant and mainly associated to refractory minerals since $(\mathrm{Hg})_{\mathrm{RC}}$ extraction yields increase with increasing depth.

\subsubsection{Influence of soil formation on the distribution of $\mathrm{Hg}$ over the soil association}

The soil association results from the ferralsols current imbalance, which leads to temporal and spatial evolutions (Boulet et al., 1993; Grimaldi et al., 2004). Because of their major role as $\mathrm{Hg}$ reservoirs, the following description of $\mathrm{Hg}$ distribution along the toposequence will thus focus on $\mathrm{OM}$ and Fe oxides behavior in the soil association.

In organic horizons, the $[\mathrm{HgT}]$ decrease along the slopes correlates with the decrease of their $\mathrm{C}$ and $\mathrm{S}$ contents. However, organic horizons in gleysols are characterized by an increased proportion of OM in gravel size fractions (>2 $\mathrm{mm}$ ) and thus by a lower degree of mineralization of coarse OM because of hydromorphy. Consequently, the overall reactivity of coarse $\mathrm{OM}$ towards $\mathrm{Hg}$ (including the reactivity of $\mathrm{S}$ groups) decreases when all soil fractions are considered even if $\mathrm{C}$ and $\mathrm{S}$ remain abundant (Andersson, 1979; Kerndorff and Schnitzer, 1980; Schnitzer and Kerndorff, 1981; Ochs et al., 1994; Gasper et al., 2007). 
The decreasing proportion of $\mathrm{Fe}$ and $\mathrm{Al}$ (oxyhydr)oxides down the slope

results from the combined effect of diffuse erosion and leaching due to the lateral drainage of horizons overlying the alteritic horizons of acrisols and of the progressive occurrence of hydromorphy (Boulet et al., 1979; Fritsch et al., 1986; Fritsch et al., 2006; Grimaldi et al., 2004; Lucas et al., 1996). Drainage induces a texture coarsening from the original clayey texture of ferralsols to the sandy-loam texture of gleysols, whereas hydromorphy induces the dissolution of crystalline and amorphous Al-bearing $\mathrm{Fe}$ oxides and the export of the reduction products through the hydrographic network (Grimaldi et al., 2008). Both processes result in the relative increase of coarse fractions composed mainly of quartz and neoformed kaolinite (Boulet, 1978; Roulet et al., 1998) which possess a low affinity for Hg (Sarkar et al., 1999; Sarkar et al., 2000).

\subsection{Influence of former gold mining activities on anthropogenic $\mathrm{Hg}$ pool in soils}

In contrast to pristine soils, $\mathrm{Hg}$ appears to be associated mainly with the prevailing sandy fraction. In highly contaminated sites $\mathrm{Hg}$ has been identified as $\mathrm{Hg}^{0}$, insoluble cinnabar and metacinnabar (Lechler et al., 1997; Slowey et al., 2005; Slowey and Brown, 2007). In the present study, mercury sulfides (cinnabar and metacinnabar) are most likely insignificant as no positive correlation was found between $\mathrm{Hg}$ and $\mathrm{S}$. $(\mathrm{Hg})_{\mathrm{HCl} / \mathrm{HNO} 3}$ extraction yields are systematically close to $100 \%$ and support further the low amount of mercury sulfides which are essentially insoluble in concentrated $\mathrm{HCl} / \mathrm{HNO}_{3}$ (Mikac et al., 2002; Mikac et al., 2003)..

The probable presence of $\mathrm{Hg}^{0}$ is supported by the observation of macroscopic $\mathrm{Hg}^{0}$ droplets during a prospective "panning" in the sandy horizon of gold-mined gleysols (50-100 cm depth) next to profile III-0. It was however impossible to assess 
668 the distribution of the $\mathrm{Hg}^{0}$ droplets along vertical profiles. $\mu \mathrm{XRF}$ confirmed the

presence of isolated $\mathrm{Hg}^{0}$ droplets $(\sim 100 \mu \mathrm{m}$ in diameter) in sample SL6 $(30-50 \mathrm{~cm})$, possibly amalgamated with micrometric gold particles. Consistently, pyrolysis measurements have shown that $\mathrm{Hg}^{0}$ generally prevail in the former gold-mined flat soils, with some exceptions (e.g., SL7 and SL8 profiles). In the latter profiles, the reduced contribution of $\mathrm{Hg}^{0}$ can result from its oxidation, known to be fast in tropical environments (Dominique et al., 2007). If geochemical conditions are not permanently reducing, as in the surface horizons, $\mathrm{Hg}^{0}$ can be oxidized, allowing adsorption onto $\mathrm{OM}$ and minerals. The relative proportion of $\mathrm{Hg}$ bond to $\mathrm{OM}$ is however lower than in pristine soils, $(\mathrm{Hg})_{\mathrm{NH} 4 \mathrm{OH}}$ extraction yields rarely exceeding $50 \%$. As previously discussed, the overall limited mineralization of $\mathrm{OM}$ is most likely responsible for the low reactivity of $\mathrm{OM}$ for $\mathrm{Hg}$. Similarly, the relative proportion of $\mathrm{Hg}$ bond to amorphous Fe oxides is low (up to 15\%), these oxides being scarce in hydromorphic environments. Finally, the part related to refractory minerals (i.e., quartz, kaolinite and muscovite) appears to be negligible since $(\mathrm{Hg})_{\mathrm{HCl} / \mathrm{HNO} 3}$ extraction yields are always close to $100 \%$.

\section{Conclusion}

The combination of selective extractions with physical techniques (XRD and $\mu \mathrm{XRF}$ ) significantly improved the determination of $\mathrm{Hg}$ speciation by allowing the identification of $\mathrm{Hg}$ carrier phases targeted by the different extractants. However, the quantification of $\mathrm{Hg}$ associated to a given carrier phase is affected by intrinsic bias, especially because of probable overlaps between the different extraction procedures. Thus, selective extractions can not be used as a standard procedure for natural 
samples since the use of selective extractions requires the preliminary assessment of reagent selectivity for a given soil matrix.

By coupling XRD and selective extractions, the main $\mathrm{Hg}$ carrier phases in pristine soils were identified as sulfur groups from organic matter, amorphous and crystalline Al-substituted Fe oxides and, to a lower extent, Al oxides. The relative contribution of these carriers to the overall $\mathrm{Hg}$ concentration was dependent on their relative abundance which is controlled by the pedogenetic evolution along the slopes, and more especially by redox conditions, hydric properties, and ecosystem engineers. In the former gold-mined flat, $\mathrm{Hg}$ was found mainly as $\mathrm{Hg}^{0}$, possibly amalgamated with $\mathrm{Au}$, and as oxidized $\mathrm{Hg}^{\prime \prime}$ associated with organic matter, $\mathrm{Fe}$ and/or Al oxides in surface horizons.

\subsection{Concluding Remarks}

These findings have major implications on the contamination of hydrosystems in tropical regions, where soil erosion due to deforestation, gold mining and agricultural processes are intense and lead to the release of $\mathrm{Hg}$-rich clay-size particles as shown by the low proportion of clay-size fractions in gold-mined gleysols. When entering suboxic and anoxic environments (e.g. river or dam sediments), $\mathrm{Hg}$ bond to clay-size particles indeed becomes accessible to ferri- and sulfato-reducing bacteria that are the main factors of $\mathrm{Hg}$ methylation (Fitzgerald and Lamborg, 2003; Fleming et al., 2006). $\mathrm{Hg}$ bound to $\mathrm{OM}$ and Fe oxides is specifically concerned as these major components of the clay-size fraction are essential nutriments for methylating micro-organisms and final electron acceptors of their metabolism. In addition, former gold mined soils are potential important sources of $\mathrm{Hg}$ for methylating bacteria. Indeed, Dominique et al. (2007) have shown that anthropogenic 
$\mathrm{Hg}^{0}$ from former gold-mining activities also promotes the production of $\mathrm{MMHg}$ in the Amazonian hydrosystems and its availability to trophic webs.

\section{Acknowledgments}

This research was supported mainly by the CNRS through its "Mercury in French Guiana" research program and by the Boulanger Mine Company (CMB Cayenne) through a Ph.D. granted to Stéphane Guédron. The authors thank Manuel Munoz and Mathieu Corazzi (LGCA - Grenoble) for the assistance with $\mu$ XRF mapping, Vincent Perrot and Nicolas Geoffroy (LGIT - Grenoble) for technical support during the project, and Max Sarrazin (IRD - Cayenne) who performed soil granulometry and $\mathrm{C}, \mathrm{N}$ and $\mathrm{S}$ analyses.

\section{References}

Andersson, A., 1979. Mercury in soils. In: J.O. Nriagu (Editor), The biogeochemistry of mercury in the environment. Elsevier, Amsterdam, pp. 80-111.

Avery, B.W. and Bascomb, C.L., 1974. Soil survey laboratory methods. Technical Monograph, 6. Soil Survey of England and Wales, Harpenden.

Barbosa, A.C., Souza, J.D., Dorea, J.G., Jardim, W.F. and Fadini, P.S., 2003. Mercury Biomagnification in a Tropical Black Water, Rio Negro, Brazil. Arch. Environ. Contam. Toxicol. 45(2): 235-246.

Barret, J., 2004. Illustrated Atlas of French Guyana. French Guyana Publications, Cayenne, 219 pp (in French).

Battke, F., Ernst, D., Fleischmann, F. and Halbach, S., 2008. Phytoreduction and volatilization of mercury by ascorbate in Arabidopsis thaliana, European beech and Norway spruce. Appl. Geochem. 23(3): 494-502. 
Beldowski, J. and Pempkowiak, J., 2003. Horizontal and vertical variabilities of mercury concentration and speciation in sediments of the Gdansk Basin, Southern Baltic Sea. Chemosphere. 52: 645-654.

Beldowski, J. and Pempkowiak, J., 2007. Mercury transformations in marine coastal sediments as derived from mercury concentration and speciation changes along source/sink transport pathway (Southern Baltic). Estuarine Coastal Shelf Sci. 72(1-2): 370-378.

Benoit, J.M., Gilmour, C.C., Heyes, A., Mason, R.P. and Miller, C.L., 2003. Geochemical and biological controls over methylmercury production and degradation in aquatic ecosystems. In: Y. Cai and O.C. Braids (Editors), Biogeochemistry of Environmentally Important Trace Elements. Oxford University Press, pp. 262-297.

Biester, H., 1994. Moglichkeiten der anwendung eines temperaturgesteuerten pyrolyseverfahrens zur bestimmung der bindungsform des quecksilbers in boden und sedimenten. Heidelberger Geowiss. Abh. 75, 156 pp.

Biester, H. and Scholz, C., 1997. Determination of mercury binding forms in contaminated soils: Mercury pyrolysis versus sequential extractions. Environ. Sci. Technol. 31: 233-239 (in German).

Bloom, N.S. and Fitzgerald, W.F., 1988. Determination of volatil mercury species at the picogram level by low-temperature gas chromatography with cold-vapor atomic fluorescence detection. Anal. Chim. Acta. 208: 151-161.

Bloom, N.S., Preus, E., Katon, J. and Hiltner, M., 2003. Selective extractions to assess the biogeochemically relevant fractionation of inorganic mercury in sediments and soils. Anal. Chim. Acta. 479: 233-248. 
Bollen, A., Wenke, A. and Biester, H., 2008. Mercury speciation analyses in $\mathrm{HgCl}_{2-}$ contaminated soils and groundwater - Implications for risk assessment and remediation strategies. Water Res. 42(1-2): 91-100.

Boszke, L., Kowalski, A., SzczuciÅ„ski, W., Rachlewicz, G., Lorenc, S.A. and Siepak, J., 2006. Assessment of mercury mobility and bioavailability by fractionation method in sediments from coastal zone inundated by the 26 December 2004 tsunami in Thailand. Environ. Geol. 51(4): 527-536.

Boulet, R., 1978. Existence of high lateral differentiation systems in French Guiana's ferrallitic soils: a new example of an imbalanced pedological cover. Soil Sci. 2: 75-82 (in French).

Boulet, R., Grugiere, J.M. and Humbel, F.X., 1979. Relationships between soil organization and water dynamics of septentrional French Guiana. Agronomic consequences of an evolution controlled by a mainly tectonic desequilibrium. Soil Sci. 1: 3-18 (in French).

Boulet, R., Lucas, Y., Fritsch, E. and Paquet, H., 1993. Landscape geochemistry: role of soil cover. In: French. Acad. Sci. (Editor), Sedimentology and surface geochemistry, Paris, pp. 55-76 (in French).

Brabo, E.S., Angelica, R.S., Silva, A.P., Faial, K.R.F., Mascarenhas, A.F.S., Santos, E.C.O., Jesus, I.M. and Loureiro, E.C.B., 2003. Assessment of mercury levels in soils, waters, bottom sediments and fishes of the Acre state in brazilian amazon. Water Air Soil poll. 147: 61-77.

Bravard, S. and Righi, D., 1991. Characterization of fulvic and humic acids from an oxisol-spodosol toposequence of Amazonia, Brazil. Geoderma. 48(1-2): 151162. 
Carmouze, J.P., Lucotte, M. and Boudou, A., 2001. Le Mercure en Amazonie Rôle de l'homme et de l'environnement, Risques sanitaires. IRD Editions, Bondy, 494 pp (in French).

Charlet, L. and Sposito, G., 1987. Monovalent ion adsorption by an oxisol. Soil Sci. Soc. Am. J. 51: 1155-1160.

Charlet, L. and Sposito, G., 1989. Bivalent ion adsorption by an Oxisol. Soil Sci. Soc. Am. J. 53(5): 691-695.

Coquery, M., Cossa, D. and Sanjuan, J., 1997. Speciation and sorption of mercury in two macro-tidal estuaries. Marine Chem. 58(1-2): 213-227.

Coquery, M., Cossa, D., Azemard, S., Peretyazhko, T. and Charlet, L., 2003. Methylmercury formation in the anoxic waters of the Petit-Saut reservoir (French Guiana) and its spreading in the adjacent Sinnamary river. J. Phys. IV. 107: 327-331.

Cossa, D. and Gobeil, C., 2000. Mercury speciation in the Lower St. Lawrence estuary. Can. J. Fish. Aquat. Sci. 57: 138-147.

De Oliveira, S.M.B., Melfi, A.J., Fostier, A.H., Forti, M.C., Favaro, D.I.T. and Boulet, R., 2001. Soils as an important sink for mercury in the Amazon. Water Air Soil Poll. 26: 321-337.

Deckers, J., Nachtergaele, F. and Spaargaren, O., 1998. World reference base for soil resources. ACCO Publishers, $165 \mathrm{pp}$.

Di Giulio, R.T. and Ryan, E.A., 1987. Mercury in soils, and clams from a North Carolina peatland. Water, Air and soil poll. 33: 205-219.

Do Nascimento, N.R., Bueno, G.T., Fritsch, E., Herbillon, A.J., Allard, T., Melfi, A.J., Astolfo, R., Boucher, H. and Li, Y., 2004. Podzolization as a deferralitization 
process: a study of an Acrisol-Podzol sequence derived from Palaeozoic sandstones in the northern upper Amazon Basin. Eur. J. Soil Sci. 55: 523-538.

Do Valle, C.M., Santana, G.P., Augusti, R., Egreja Filho, F.B. and Windmoller, C.C., 2005. Speciation and quantification of mercury in Oxisol, Ultisol, and Spodosol from Amazon (Manaus, Brazil). Chemosphere. 58(6): 779-792.

Doering, E.R., Havrilla, G.J. and Miller, T.C., 2004. Disilicide Diffusion Coating Inspection by Micro X-Ray Fluorescence Imaging. J. Nondestr. Eval., 23(3): 95-105.

Dominique, Y., Muresan, B., Duran, R., Richard, S. and Boudou, A., 2007. Simulation of the Chemical Fate and Bioavailability of Liquid Elemental Mercury Drops from Gold Mining in Amazonian Freshwater Systems. Environ. Sci. Tech. 41(21): $7322-7329$.

Eagenhouse, R.P., Young, D.R. and Johnson, J.N., 1978. Geochemistry of mercury in Palos Verdes sediments. Environ. Sci. Technol. 12: 1151-1157.

Evain, M., 1992. U-FIT: A Cell Parameter Refinement Program. IMN Nantes.

Fitzgerald, W.F. and Lamborg, C.H., 2003. Geochemistry of mercury in the environment. In: B. Sherwood Lollar (Editor), Treatise on Geochemistry. Elsevier, pp. 107-148.

Fleming, E.J., Mack, E.E., Green, P.G. and Douglas, C.N., 2006. Mercury methylation from unexpected sources: molybdate-inhibited freshwater sediments and iron-reducing bacterium. Appl. Environ. Microbiol. 72(1): 457464.

Fontes, M.P.F. and Gomes, P.C., 2003. Simultaneous competitive adsorption of heavy metals by the mineral matrix of tropical soils. Appl. Geochem. 18(6): 795-804. 
Frery, N., Maury-Brachet, R., Maillot, E., Deheeger, M., Merona de, B. and Boudou, A., 2001. Goldmining activities and mercury contamination of native Amerindian communities in french Guiana: key role of fish in dietary uptake. Environ. Health Persp. 109: 449-456.

Fritsch, E., Bocquier, G., Boulet, R., Dosso, M. and Humbel, F.X., 1986. Transforming systems of ferrallitic cover in French Guiana, structural analysis of a supergene formation and mode of representation. ORSTOM notebook, Pedol. Ser. 12(4): 361-395 (in French).

Fritsch, E., Morin, G., Bedidi, A., Bonnin, D., Balan, E., Caquineau, S. and Calas, G., 2005. Transformation of haematite and Al-poor goethite to Al-rich goethite and associated yellowing in a ferralitic clay soil profile of the middle Amazon Basin (Manaus, Brazil). Eur. J. Soil Sci. 56(5): 575-588.

Fritsch, E., Herbillon, A.J., doNascimento, N.R., Grimaldi, M. and Melfi, A.J., 2006. From Plinthic Acrisols to Plinthosols and Gleysols: iron and groundwater dynamics in the tertiary sediments of the upper Amazon basin. Eur. J. Soil Sci. 58: 989-1006.

Gasper, J.D., Aiken, G.R. and Ryan, J.N., 2007. A critical review of three methods used for the measurement of mercury $\left(\mathrm{Hg}^{2+}\right)$-dissolved organic matter stability constants. Appl. Geochem. 22(8): 1583-1597.

Grimaldi, C., Grimaldi, M., Millet, A., Bariac, T. and Boulègue, J., 2004. Behavior of chemical solutes during a storm in a rainforested headwater catchment. Hydrol. Process. 18: 93-106.

Grimaldi, C., Guedron, S. and Grimaldi, M., 2008. Mercury distribution in tropical soil profiles related to origin of mercury and soil processes. Sci. Total Environ. 401: $121-129$. 
860 Grimaldi, M., Gaudet, J.P., Grimaldi, C., Melieres, M.A. and Spadini, L., 2001. Sources, budget and transfers in soils and sediments. In: CNRS (Editor), Mercury in French Guiana research Program. Final report, part one: the region of Saint Elie and the Petit Saut reservoir. CNRS-PEVS, pp. 5-15 (in French).

Guedron, S., Grimaldi, C., Chauvel, C., Spadini, C. and Grimaldi, M., 2006. Weathering versus atmospheric contributions to mercury concentrations in French Guiana soils. Appl. Geochem. 21: 2010-2022.

Guehl, J.M., 1984. Water dynamic in French Guiana tropical humid forest soil. Influence of the pedological cover . Ann. For. Sci. 41(2): 195-236 (in French).

Kerndorff, H. and Schnitzer, M., 1980. Sorption of metals on humic acid . Geochim. Cosmochim. Acta. 44: 1701-1708.

Khwaja, A., Bloom, P.R. and Brezonik, P.L., 2006. Binding constants of divalent Mercury $\left(\mathrm{Hg}^{2+}\right)$ in soil humic acids and soil organic matter. Environ. Sci. Technol. 40: 844-849.

Kim, C., Rytuba, J. and Brown, J.G.E., 2004a. EXAFS study of mercury (II) sorption to Fe- and Al- (hydr)oxides I. Effect of chloride and sulfate. J. Colloid Interface Sci. 270: 9-20.

Kim, C., Rytuba, J.J. and Brown, J.G.E., 2004b. EXAFS study of mercury (II) sorption to Fe- and Al- (hydr)oxides I. Effect of pH. J. Colloid Interface Sci. 271: 1-15.

Kostka, J.E. and Luther III, G.W., 1994. Partitioning and speciation of solid phase iron in saltmarsh sediments. Geochim. Cosmochim. Acta. 58(7): 1701-1710.

Lacerda, L.D., 1997. Global mercury emissions from gold and silver mining. Water Air Soil Poll. 97: 209-221.

Lebel, J., Mergler, D., Lucotte, M., Amorin, M., Dolbec, J., Miranda, D., Arantes, G., Rhéault, I. and Pichet, P., 1996. Evidence of early nervous system disfunction 
in Amazonian populations exposed to low levels of methylmercury. Neurotoxicol. 17: 157-168.

Lechler, P.J., Miller, J.R., Hsu, L.-C. and Desilets, M.O., 1997. Mercury mobility at the Carson River Superfund Site, west-central Nevada, USA: Interpretation of mercury speciation data in mill tailings, soils, and sediments. J. Geochem. Explor. 58(2-3): 259-267.

Lechler, P.J., Miller, J.R., Lacerda, L.D., Vinson, D., Bonzongo, J.-C., Lyons, W.B. and Warwick, J.J., 2000. Elevated mercury concentrations in soils, sediments, water, and fish of the Madeira River basin, Brazilian Amazon: a function of natural enrichments? Sci. Total Environ. 260: 87-96.

Leermakers, M., Baeyens, W., Quevauviller, P. and Horvat, M., 2005. Mercury in environmental samples: Speciation, artifacts and validation. Trends Anal. Chem. 24(5): 383-393.

Lucas, Y., Nahon, D., Cornu, S. and Eyrolle, F., 1996. Soil genesis and dynamics in equatorial areas. C. R. Acad. Sci. 322(1): 1-16 (In French).

Malengreau, N. and Sposito, G., 1997. Short-time dissolution mechanisms of kaolinitic tropical soils. Geochim. Cosmochim. Acta; 61(20): 4297-4307.

Manceau, A. and Nagy, K.L., 2008. Relationships between Hg(II)-S bond distance and $\mathrm{Hg}(\mathrm{II})$ coordination in thiolates. Dalton Trans. 11: 1385-1508.

Mikac, N., Foucher, D., Niessen, S. and Fischer, J.-C., 2002. Extractability of HgS (cinnabar and metacinnabar) by hydrochloric acid. Anal. Bioanal. Chem. 374(6): 1028-1033.

Mikac, N., Foucher, D., Niessen, S., Lojen, S. and Fischer, J.-C., 2003. Influence of chloride and sediment matrix on the extractability of $\mathrm{HgS}$ (cinnabar and metacinnabar) by nitric acid. Anal. Bioanal. Chem. 377(7): 1196-1201. 
Milési, J.P., Egal, E., Ledru, P., Vernhet, Y., Thiéblemont, D., Cocherie, A., Tegyey, M., Martel-Jantin, B. and Lagny, P., 1995. Mineralizations of the northern French Guiana in their geological setting. Mining Res. Chron. 518: 5-58 (in French).

Molicova, H., Grimaldi, M., Bonell, M. and Hubert, P., 1997. Using TOPMODEL towards identifying and modelling the hydrological patterns within a headwater humid, tropical catchment. Hydrolog. Process. 11: 1169-1196.

Ochs, M., Cosovic, B. and Stumm, W., 1994. Coordinative and hydrophobic interaction of humic substances with hydrophilic $\mathrm{Al}_{2} \mathrm{O}_{3}$ and hydrophobic mercury surfaces. Geochim. Cosmochim. Acta. 58(2): 639-650.

Richard, S., Arnoux, A., Cerdan, P., Reynouard, C. and Horeau, V., 2000. Mercury levels of soils, sediments and fish in French Guiana, South America. Water Air Soil Poll. 124: 221-244.

Rodriguez Martin-Doimeadios, R.C., Wasserman, J.C., Garcia Bermejo, L.F., Amouroux, D., Berzas Nevado, J.J. and Donard, O.F.X., 2000. Chemical availability of mercury in stream sediments from the Almaden area, Spain. J. Environ. Monit. 2: 360-366.

Roos-Barraclough, F., Givelet, N., Martinez-Cortizas, A., Goodsite, M.E., Biester, H. and Shotyk, W., 2002. An analytical protocol for determination of total mercury concentration in solid peat samples. Sci. Tot. Environ. 292: 129-139.

Roulet, M. and Lucotte, M., 1995. Geochemistry of mercury in pristine and flooded ferralitic soil of a tropical rain forest in French Guiana, South America. Water, Air, Soil Poll. 80: 1079-1088.

Roulet, M., Lucotte, M., Saint-Aubin, A., Tran, S., Rheault, I., Farella, N., Da Silva, E.D., Dezencourt, J., Passos, C.J.S., Soares, G.S., Guimaraes, J.R.D., 
Mergler, D. and Amorim, M., 1998. The geochemistry of mercury in central Amazonian soils developed on the Alter-do-Chao formation of the lower Tapajos River Valley, Para state, Brazil. Sci. Total Environ. 223(1): 1-24.

Rowell, D.L., 1994. Soil Science : methods and applications. British Library, Harlow (England).

Sanchez, D.M., Quejido, A.J., Fernandez, M., Hernandez, C., Schmid, T., Millan, R., Gonzalez, M., Aldea, M., Martan, R. and Morante, R., 2005. Mercury and trace element fractionation in Almaden soils by application of different sequential extraction procedures. Anal. Bioanal. Chem. 381(8): 1507-1513.

Sarkar, D., Essington, M.E. and Misra, K.C., 1999. Adsorption of mercury(II) by variable charge surfaces of quartz and gibbsite. Soil Sci. Soc. Am. J. 63: 1626-1636.

Sarkar, D., Essington, M.E. and Misra, K.C., 2000. Adsorption of mercury(II) by kaolinite. Soil Sci. Soc. Am. J. 64: 1698-1975.

Schnitzer, M. and Kerndorff, H., 1981. Reactions of fulvic acid with metal ions. Water, Air, Soil Poll. 15: 97-108.

Schulze, D.G., 1984. The influence of aluminium on iron oxides. VIII. Unit-cell dimension of Al-substituted goethites and estimation of Al from them. Clays Clay Miner. 32(1): 36-44.

Schuster, E., 1991. The behavior of mercury in the soil with special emphasis on complexation and adsorption processes- a review of the literature. Water Air Soil Poll. 56: 667-680.

Schwertmann, U. and Latham, M., 1986. Properties of iron oxides in some new caledonian oxisols. Geoderma. 39: 105-123. 
Schwertmann, U. and Cornell, R.M., 2000. Iron oxides in the laboratory : preparation and characterization. Wiley- $\mathrm{VCH}$, Weinheim, $188 \mathrm{pp}$.

Shannon, R., 1976. Revised effective ionic radii and systematic studies of interatomic distances in halides and chalcogenides. Acta Crystallogr. 32(5): 751-767.

Skyllberg, U., Xia, K., Bloom, P.R., Nater, E.A. and Bleam, W.F., 2000. Binding of mercury(II) to reduced sulfur in soil organic matter along upland-peat soil transects. J. Environ. Qual. 29: 855-865.

Skyllberg, U., Bloom, P.R., Qian, J., Lin, C.-M. and Bleam, W.F., 2006. Complexation of Mercury(II) in Soil Organic Matter: EXAFS Evidence for Linear TwoCoordination with Reduced Sulfur Groups. Environ. Sci. Technol. 40(13): 4174-4180.

Sladek, C. and Gustin, M.S., 2003. Evaluation of sequential and selective extraction methods for determination of mercury speciation and mobility in mine waste. Appl. Geochem. 18(4): 567-576.

Slowey, A.J., Rytuba, J.J. and Brown, J.G.E., 2005. Speciation of mercury and mode of transport from placer Gold Mine Tailings. Environ. Sci. Technol. 39(6): 1547-1554.

Slowey, A.J. and Brown, J.G.E., 2007. Transformations of mercury, iron, and sulfur during the reductive dissolution of iron oxyhydroxide by sulfide. Geochim. Cosmochim. Acta. 71(4): 877-894.

Stanjek, H. and Schwertmann, U., 1992. The influence of aluminium on iron oxides. Part XVI: hydroxyl and aluminium substitution on synthetic hematites. Clays Clay Miner. 40(3): 347-354.

Tandy, J.C., Grimaldi, M., Grimaldi, C. and Tessier, D., 1990. Mineralogical and textural changes in French Guiana oxisols and their relation with 
microaggregation. In: L.A. Douglas (Editor), Soil micromorphology. A basic and applied science. 8. International Working Meeting of Soil Micromorphology. Developments in Soil Science. Elsevier, Amsterdam, pp. 191-198.

Trivedi, P. and Axe, L., 2001. Ni and $\mathrm{Zn}$ Sorption to Amorphous versus Crystalline Iron Oxides: Macroscopic Studies. J. Colloid Interface Sci., 244: 221-229.

Veiga, M. and Baker, R., 2004. Protocols for environmental and health assessment of mercury released by artisanal and small scale miners. Report to the Global mercury project: removal of barriers to introduction of cleaner artisanal gold mining and extraction technologies, GEF/UNDP/UNIDO; 2004. p. 170.

Velasquez, E., Pelosi, C., Brunet, D., Grimaldi, M., Martins, M., Rendeiro, A.C., Barrios, E. and Lavelle, P., 2007. This ped is my ped: Visual separation and near infrared spectra allow determination of the origins of soil macroaggregates. Pedobiologia. 51(1): 75-87.

Wallschlager, D., Desai, M.V.M., Spengler, M. and Wilken, R.-D., 1998. Mercury speciation in floodplain soils and sediments along a contaminated river transect. J. Environ. Qual. 27: 1034-1044.

Webster, R., 2001. Statistics to support soil research and their presentation. Eur. J. Soil Sci. 52(2): 331-340.

Weerasooriya, R., Tobschall, H.J., Seneviratne, W. and Bandara, A., 2007. Transition state kinetics of $\mathrm{Hg}(\mathrm{II})$ adsorption at gibbsite-water interface. J. Hazard. Mater. 147(3): 971-978.

Wentworth, C.K., 1922. A scale of grade and class terms for clastic sediments. J. Geol. 30: 377-392. 
Table 1: $\quad$ Pearson correlation matrix (correlation coefficient $(C C), P$ value $(P)$ and number of samples $(\mathrm{N})$ ) of pristine soils extracted $\mathrm{Hg}, \mathrm{Hg}$ extraction yields, $\mathrm{Fe}, \mathrm{Al}$, Clay size fraction, Fine silts, $\mathrm{C}$ and $\mathrm{S}$ for total and (a) $\mathrm{HCl} / \mathrm{HNO}_{3}$ (labeled $\mathrm{HCl}$ ) and ascorbate (labeled Asco) selective extractions, and (b) $\mathrm{KOH}$ and $\mathrm{NH}_{4} \mathrm{OH}$ selective extractions. 
Table 1a

\begin{tabular}{|c|c|c|c|c|c|c|c|c|c|c|c|c|c|c|c|c|c|c|}
\hline & $\begin{array}{l}\text { Stati } \\
\text { stics }\end{array}$ & $\begin{array}{l}{[\mathrm{Hg}]_{\mathrm{HCl}}} \\
\left(\mu \mathrm{g} \mathrm{g}^{-1}\right)\end{array}$ & $\begin{array}{c}(\mathrm{Hg})_{\mathrm{HCl}} \\
(\%)\end{array}$ & $\begin{array}{c}{[\mathrm{Fe}]_{\mathrm{HCl}}} \\
\left(\mathrm{mg} \mathrm{g}^{-1}\right)\end{array}$ & $\begin{array}{c}{[\mathrm{Al}]_{\mathrm{HCl}}} \\
\left(\mathrm{mg} \mathrm{g}^{-1}\right)\end{array}$ & $\begin{array}{c}\text { Clay } \\
(\mathrm{g} / 100 \mathrm{~g})\end{array}$ & $\begin{array}{c}\text { Silt } \\
\text { (g/100g) }\end{array}$ & $\begin{array}{c}C \\
(g / 100 g)\end{array}$ & $\begin{array}{c}S \\
(g / 100 g)\end{array}$ & & $\begin{array}{l}{[\mathrm{Hg}]_{\mathrm{KOH}}} \\
\left(\mu \mathrm{g} \mathrm{g}^{-1}\right)\end{array}$ & $\begin{array}{c}(\mathrm{Hg})_{\mathrm{KOH}} \\
(\%)\end{array}$ & $\begin{array}{l}{[\mathrm{Fe}]_{\mathrm{KOH}}} \\
\left(\mathrm{mg} \mathrm{g}^{-1}\right)\end{array}$ & $\begin{array}{c}{[\mathrm{Al}]_{\mathrm{KOH}}} \\
\left(\mathrm{mg} \mathrm{g}^{-1}\right)\end{array}$ & $\begin{array}{c}\text { Clay } \\
(\mathrm{g} / 100 \mathrm{~g})\end{array}$ & $\begin{array}{c}\text { Silt } \\
\text { (g/100g) }\end{array}$ & $\underset{(g / 100 g)}{C}$ & $\begin{array}{c}S \\
(g / 100 g)\end{array}$ \\
\hline \multirow{3}{*}{$\begin{array}{c}{[\mathrm{HgT}]} \\
\left(\mu \mathrm{g} \mathrm{g}^{-1}\right)\end{array}$} & $\mathrm{CC}$ & 1.00 & 0.45 & 0.19 & 0.15 & 0.59 & -0.60 & 0.42 & 0.62 & \multirow{3}{*}{$\begin{array}{c}{[\mathrm{HgT}]} \\
\left(\mu \mathrm{g} \mathrm{g}^{-1}\right)\end{array}$} & 0.89 & 0.32 & 0.33 & 0.37 & 0.59 & -0.60 & 0.42 & 0.62 \\
\hline & $\mathrm{P}$ & 1.E-41 & 3.E-03 & 2.E-01 & 3.E-01 & 9.E-05 & 7.E-05 & 7.E-03 & 2.E-05 & & 7.E-14 & 5.E-02 & 5.E-02 & 3.E-02 & 9.E-05 & 7.E-05 & 7.E-03 & 2.E-05 \\
\hline & $N$ & 40 & 40 & 40 & 40 & 38 & 38 & 40 & 40 & & 38 & 38 & 36 & 36 & 38 & 38 & 40 & 40 \\
\hline \multirow{3}{*}{$\begin{array}{l}{[\mathrm{Hg}]_{\mathrm{HCl}}} \\
\left(\mu \mathrm{g} \mathrm{g}^{-1}\right)\end{array}$} & $\mathrm{CC}$ & & 0.48 & 0.18 & 0.13 & 0.56 & - 0.57 & 0.40 & 0.58 & \multirow{3}{*}{$\begin{array}{c}{[\mathrm{Hg}]_{\mathrm{KOH}}} \\
\left(\mu \mathrm{g} \mathrm{g}^{-1}\right)\end{array}$} & & 0.63 & 0.21 & 0.15 & 0.48 & -0.42 & 0.26 & 0.51 \\
\hline & $\mathrm{P}$ & & 2.E-03 & 3.E-01 & 4.E-01 & 3.E-04 & 2.E-04 & 1.E-02 & 9.E-05 & & & 2.E-05 & 2.E-01 & 4.E-01 & 3.E-03 & 1.E-02 & 1.E-01 & 1.E-03 \\
\hline & $N$ & & 40 & 40 & 40 & 38 & 38 & 40 & 40 & & & 38 & 36 & 36 & 36 & 36 & 38 & 38 \\
\hline \multirow{3}{*}{$\begin{array}{c}(\mathrm{Hg})_{\mathrm{HCl}} \\
(\%)\end{array}$} & $\mathrm{CC}$ & & & 0.25 & 0.16 & 0.38 & -0.44 & 0.31 & 0.28 & \multirow{3}{*}{$\begin{array}{c}(\mathbf{H g})_{\mathrm{KOH}} \\
(\%)\end{array}$} & & & -0.02 & - 0.10 & 0.38 & -0.28 & 0.15 & 0.33 \\
\hline & $\mathrm{P}$ & & & 1.E-01 & 3.E-01 & 2.E-02 & 6.E-03 & 5.E-02 & 8.E-02 & & & & 9.E-01 & $6 . \mathrm{E}-01$ & 2.E-02 & 1.E-01 & 4.E-01 & 4.E-02 \\
\hline & $\mathrm{N}$ & & & 40 & 40 & 38 & 38 & 40 & 40 & & & & 36 & 36 & 36 & 36 & 38 & 38 \\
\hline \multirow{3}{*}{$\begin{array}{c}{[\mathrm{Fe}]_{\mathrm{HCl}}} \\
\left(\mathrm{mg} \mathrm{g}^{-1}\right)\end{array}$} & $\mathrm{CC}$ & & & & 0.69 & 0.34 & - 0.33 & 0.16 & 0.24 & \multirow{3}{*}{$\begin{array}{l}{[\mathrm{Fe}]_{\mathrm{KOH}}} \\
\left(\mathrm{mg} \mathrm{g}^{-1}\right)\end{array}$} & & & & 0.60 & 0.62 & -0.38 & - 0.15 & 0.48 \\
\hline & $\mathrm{P}$ & & & & 8.E-07 & 4.E-02 & 4.E-02 & 3.E-01 & 1.E-01 & & & & & 1.E-04 & 1.E-04 & 2.E-02 & 4.E-01 & 3.E-03 \\
\hline & $N$ & & & & 40 & 38 & 38 & 40 & 40 & & & & & 36 & 34 & 34 & 36 & 36 \\
\hline \multirow{3}{*}{$\begin{array}{c}{[\mathrm{Al}]_{\mathrm{HCl}}} \\
\left(\mathrm{mg} \mathrm{g}^{-1}\right)\end{array}$} & $\mathrm{CC}$ & & & & & 0.57 & -0.42 & 0.12 & 0.39 & \multirow{3}{*}{$\begin{array}{c}{[\mathrm{Al}]_{\mathrm{KOH}}} \\
\left(\mathrm{mg} \mathrm{g}^{-1}\right)\end{array}$} & & & & & 0.68 & -0.48 & 0.16 & 0.50 \\
\hline & $\mathrm{P}$ & & & & & 2.E-04 & 9.E-03 & 5.E-01 & 1.E-02 & & & & & & 1.E-05 & 4.E-03 & 4.E-01 & 2.E-03 \\
\hline & $\mathrm{N}$ & & & & & 38 & 38 & 40 & 40 & & & & & & 34 & 34 & 36 & 36 \\
\hline \multirow{3}{*}{$\begin{array}{c}\text { Clay } \\
(g / 100 g)\end{array}$} & $\mathrm{CC}$ & & & & & & -0.80 & 0.37 & 0.80 & \multirow{3}{*}{$\begin{array}{c}\text { Clay } \\
(\mathrm{g} / 100 \mathrm{~g})\end{array}$} & & & & & & - 0.80 & 0.37 & 0.80 \\
\hline & $\mathrm{P}$ & & & & & & 3.E-09 & 2.E-02 & 2.E-09 & & & & & & & 3.E-09 & 2.E-02 & 2.E-09 \\
\hline & $N$ & & & & & & 38 & 38 & 38 & & & & & & & 38 & 38 & 38 \\
\hline \multirow{3}{*}{$\begin{array}{c}\text { Silt } \\
(g / 100 g)\end{array}$} & $\mathrm{CC}$ & & & & & & & - 0.57 & - 0.70 & \multirow{3}{*}{$\begin{array}{c}\text { Silt } \\
(\mathrm{g} / 100 \mathrm{~g})\end{array}$} & & & & & & & - 0.57 & - 0.70 \\
\hline & $\mathrm{P}$ & & & & & & & 2.E-04 & 1.E-06 & & & & & & & & 2.E-04 & 1.E-06 \\
\hline & $\mathrm{N}$ & & & & & & & 38 & 38 & & & & & & & & 38 & 38 \\
\hline \multirow{3}{*}{$\underset{(g / 100 g)}{C}$} & $\mathrm{CC}$ & & & & & & & & 0.47 & \multirow{3}{*}{$\underset{(g / 100 g)}{C}$} & & & & & & & & 0.47 \\
\hline & $\mathrm{P}$ & & & & & & & & 0.00251 & & & & & & & & & 3.E-03 \\
\hline & $\mathrm{N}$ & & & & & & & & 40 & & & & & & & & & 40 \\
\hline
\end{tabular}


Table 1b

\begin{tabular}{|c|c|c|c|c|c|c|c|c|c|c|c|c|c|c|c|c|c|c|}
\hline & $\begin{array}{l}\text { Stati } \\
\text { stics }\end{array}$ & $\begin{array}{l}{[\mathrm{Hg}]_{\text {Asco }}} \\
\left(\mu \mathrm{g} \mathrm{g}^{-1}\right)\end{array}$ & $\begin{array}{c}(\mathrm{Hg})_{\text {Asco }} \\
(\%)\end{array}$ & $\begin{array}{l}{[\mathrm{Fe}]_{\text {Asco }}} \\
\left(\mathrm{mg} \mathrm{g}^{-1}\right)\end{array}$ & $\begin{array}{l}{[\mathrm{Al}]_{\text {Asco }}} \\
\left(\mathrm{mg} \mathrm{g}^{-1}\right)\end{array}$ & $\begin{array}{c}\text { Clay } \\
\text { (g/100g) }\end{array}$ & $\begin{array}{c}\text { Silt } \\
(\mathrm{g} / 100 \mathrm{~g})\end{array}$ & $\begin{array}{c}C \\
(g / 100 g)\end{array}$ & $\begin{array}{c}S \\
(g / 100 g)\end{array}$ & & $\begin{array}{c}{[\mathrm{Hg}]_{\mathrm{NH} 4 \mathrm{OH}}} \\
\left(\mu \mathrm{g} \mathrm{g}^{-1}\right)\end{array}$ & $\begin{array}{c}(\mathrm{Hg})_{\mathrm{NH} 4 \mathrm{OH}} \\
(\%)\end{array}$ & $\begin{array}{c}{[\mathrm{Fe}]_{\mathrm{NH} 4 \mathrm{OH}}} \\
\left(\mathrm{mg} \mathrm{g}^{-1}\right)\end{array}$ & $\begin{array}{c}{[\mathrm{Al}]_{\mathrm{NH} 4 \mathrm{OH}}} \\
\left(\mathrm{mg} \mathrm{g}^{-1}\right)\end{array}$ & $\begin{array}{c}\text { Clay } \\
(\mathrm{g} / 100 \mathrm{~g})\end{array}$ & $\begin{array}{c}\text { Silt } \\
(\mathrm{g} / 100 \mathrm{~g})\end{array}$ & $\begin{array}{c}C \\
(g / 100 g)\end{array}$ & $\begin{array}{c}S \\
(g / 100 g)\end{array}$ \\
\hline \multirow{3}{*}{$\begin{array}{c}{[\mathrm{HgT}]} \\
\left(\mu \mathrm{g} \mathrm{g}^{-1}\right)\end{array}$} & $\mathrm{CC}$ & 0.77 & 0.21 & 0.40 & 0.35 & 0.59 & -0.60 & 0.42 & 0.62 & \multirow{3}{*}{$\begin{array}{c}{[\mathrm{HgT}]} \\
\left(\mu \mathrm{g} \mathrm{g}^{-1}\right)\end{array}$} & 0.90 & 0.45 & 0.27 & 0.08 & 0.59 & -0.60 & 0.42 & 0.62 \\
\hline & $\mathrm{P}$ & 1.E-08 & 2.E-01 & 1.E-02 & 3.E-02 & 9.E-05 & 7.E-05 & 7.E-03 & 2.E-05 & & 2.E-15 & 4.E-03 & 1.E-01 & 6.E-01 & 9.E-05 & 7.E-05 & 7.E-03 & 2.E-05 \\
\hline & $N$ & 39 & 39 & 40 & 40 & 38 & 38 & 40 & 40 & & 40 & 40 & 39 & 40 & 38 & 38 & 40 & 40 \\
\hline \multirow{3}{*}{$\begin{array}{c}{[\mathrm{Hg}]_{\text {Asco }}} \\
\left(\mu \mathrm{g} \mathrm{g}^{-1}\right)\end{array}$} & $\mathrm{CC}$ & & 0.73 & 0.68 & 0.60 & 0.64 & -0.66 & 0.56 & 0.59 & {$[\mathrm{Ha}]_{\mu}$} & & 0.74 & 0.31 & 0.08 & 0.70 & -0.70 & 0.65 & 0.71 \\
\hline & $\mathrm{P}$ & & 2.E-07 & 2.E-06 & 5.E-05 & 2.E-05 & 9.E-06 & 2.E-04 & 8.E-05 & {$\left[\right.$ [ng] ${ }_{\mathrm{NH} 4 \mathrm{OH}}$} & & 4.E-08 & 6.E-02 & 6.E-01 & 1.E-06 & 9.E-07 & 7.E-06 & 3.E-07 \\
\hline & $N$ & & 39 & 39 & 39 & 37 & 37 & 39 & 39 & $\left(\boldsymbol{\mu g} \mathbf{g}^{-1}\right)$ & & 40 & 39 & 40 & 38 & 38 & 40 & 40 \\
\hline \multirow{3}{*}{$\begin{array}{c}(\mathrm{Hg})_{\text {Asco }} \\
(\%)\end{array}$} & $\mathrm{CC}$ & & & 0.62 & 0.51 & 0.39 & -0.35 & 0.37 & 0.32 & & & & 0.23 & 0.06 & 0.68 & -0.68 & 0.67 & 0.67 \\
\hline & $P$ & & & 3.E-05 & 9.E-04 & 2.E-02 & 4.E-02 & 2.E-02 & 4.E-02 & $(\mathrm{Hg})_{\mathrm{NH} 4 \mathrm{OH}}$ & & & 2.E-01 & 7.E-01 & 3.E-06 & 3.E-06 & 2.E-06 & 2.E-06 \\
\hline & $\mathrm{N}$ & & & 39 & 39 & 37 & 37 & 39 & 39 & & & & 39 & 40 & 38 & 38 & 40 & 40 \\
\hline \multirow{3}{*}{$\begin{array}{l}{[\mathrm{Fe}]_{\text {Asco }}} \\
\left(\mathrm{mg} \mathrm{g}^{-1}\right)\end{array}$} & $\mathrm{CC}$ & & & & 0.98 & 0.42 & -0.52 & 0.30 & 0.37 & [Fe] & & & & 0.64 & 0.06 & -0.24 & 0.23 & 0.15 \\
\hline & $\mathrm{P}$ & & & & 3.E-27 & 8.E-03 & 7.E-04 & 6.E-02 & 2.E-02 & {$[r e]_{N H 4 O H}$} & & & & 1.E-05 & 7.E-01 & 2.E-01 & 2.E-01 & 4.E-01 \\
\hline & $N$ & & & & 40 & 38 & 38 & 40 & 40 & $(\mathrm{mg} \mathrm{g})$ & & & & 39 & 37 & 37 & 39 & 39 \\
\hline \multirow{3}{*}{$\begin{array}{l}{[\mathrm{Al}]_{\text {Asso }}} \\
\left(\mathrm{mg} \mathrm{g}^{-1}\right)\end{array}$} & $\mathrm{CC}$ & & & & & 0.37 & - 0.47 & 0.22 & 0.31 & & & & & & -0.01 & - 0.22 & 0.06 & - 0.07 \\
\hline & $\mathrm{P}$ & & & & & 2.E-02 & 3.E-03 & 2.E-01 & 5.E-02 & {$[A 1]_{\mathrm{NH} 4 \mathrm{OH}}$} & & & & & 9.E-01 & 2.E-01 & 7.E-01 & 7.E-01 \\
\hline & $N$ & & & & & 38 & 38 & 40 & 40 & $\left(\mathrm{mg} \mathrm{g}^{-1}\right)$ & & & & & 38 & 38 & 40 & 40 \\
\hline \multirow{3}{*}{$\begin{array}{c}\text { Clay } \\
\text { (g/100g) }\end{array}$} & $\mathrm{CC}$ & & & & & & -0.80 & 0.37 & 0.80 & & & & & & & - 0.80 & 0.37 & 0.80 \\
\hline & $\mathrm{P}$ & & & & & & 3.E-09 & 2.E-02 & 2.E-09 & (a/100a) & & & & & & 3.E-09 & 2.E-02 & 2.E-09 \\
\hline & $N$ & & & & & & 38 & 38 & 38 & & & & & & & 38 & 38 & 38 \\
\hline \multirow{3}{*}{$\begin{array}{c}\text { Silt } \\
\text { (g/100g) }\end{array}$} & $\mathrm{CC}$ & & & & & & & -0.57 & -0.70 & & & & & & & & - 0.57 & -0.70 \\
\hline & $\mathrm{P}$ & & & & & & & 2.E-04 & 1.E-06 & (a/100a) & & & & & & & 2.E-04 & 1.E-06 \\
\hline & $\mathrm{N}$ & & & & & & & 38 & 38 & & & & & & & & 38 & 38 \\
\hline \multirow{3}{*}{$\begin{array}{c}C \\
(g / 100 g)\end{array}$} & $\mathrm{CC}$ & & & & & & & & 0.47 & & & & & & & & & 0.47 \\
\hline & $P$ & & & & & & & & 3.E-03 & $C(g / 100 g)$ & & & & & & & & 3.E-03 \\
\hline & $\mathrm{N}$ & & & & & & & & 40 & & & & & & & & & 40 \\
\hline
\end{tabular}


Table 2: Pearson correlation matrix (correlation coefficient $(\mathrm{CC}), \mathrm{P}$ value $(\mathrm{P})$ and number of samples $(\mathrm{N})$ ) of contaminated soils extracted $\mathrm{Hg}, \mathrm{Hg}$ extraction yields, Fe, Al, Clay size fraction, Fine silts, C and S for total and (a) $\mathrm{HCl} / \mathrm{HNO}_{3}$ (labeled $\mathrm{HCl}$ ) and ascorbate (labeled Asco) selective extractions, and (b) $\mathrm{KOH}$ and $\mathrm{NH}_{4} \mathrm{OH}$ selective extractions. 
Table 2a

\begin{tabular}{|c|c|c|c|c|c|c|c|c|c|c|c|c|c|c|c|c|c|c|}
\hline & $\begin{array}{l}\text { Stati } \\
\text { stics }\end{array}$ & $\begin{array}{l}{[\mathrm{Hg}]_{\mathrm{HCI}}} \\
\left(\mu \mathrm{g} \mathrm{g}^{-1}\right)\end{array}$ & $\begin{array}{c}(\mathrm{Hg})_{\mathrm{HCl}} \\
(\%)\end{array}$ & $\begin{array}{l}{[\mathrm{Fe}]_{\mathrm{HCl}}} \\
\left(\mathrm{mg} \mathrm{g}^{-1}\right)\end{array}$ & $\begin{array}{c}{[\mathrm{Al}]_{\mathrm{HCl}}} \\
\left(\mathrm{mg} \mathrm{g}^{-1}\right)\end{array}$ & $\begin{array}{c}\text { Clay } \\
\text { (g/100g) }\end{array}$ & $\begin{array}{l}\text { Sand } \\
\text { (g/100g) }\end{array}$ & $\begin{array}{c}C \\
\text { (g/100g) }\end{array}$ & $\begin{array}{c}S \\
(g / 100 g)\end{array}$ & & $\begin{array}{l}{[\mathrm{Hg}]_{\mathrm{KOH}}} \\
\left(\mu \mathrm{g} \mathrm{g}^{-1}\right)\end{array}$ & $\begin{array}{c}(\mathrm{Hg})_{\text {кон }} \\
(\%)\end{array}$ & $\begin{array}{l}{[\mathrm{Fe}]_{\mathrm{KOH}}} \\
\left(\mathrm{mg} \mathrm{g}^{-1}\right)\end{array}$ & $\begin{array}{l}{[\mathrm{Al}]_{\mathrm{KOH}}} \\
\left(\mathrm{mg} \mathrm{g}^{-1}\right)\end{array}$ & $\begin{array}{c}\text { Clay } \\
\text { (g/100g) }\end{array}$ & $\begin{array}{l}\text { Sand } \\
(\mathrm{g} / 100 \mathrm{~g})\end{array}$ & $\begin{array}{c}C \\
(g / 100 g)\end{array}$ & $\begin{array}{c}S \\
(g / 100 g)\end{array}$ \\
\hline \multirow{3}{*}{$\begin{array}{c}{[\mathrm{HgT}]} \\
\left(\mu \mathrm{g} \mathrm{g} \mathrm{g}^{-1}\right)\end{array}$} & CC & 1.00 & 0.22 & -0.29 & -0.34 & -0.52 & 0.50 & 0.09 & $\begin{array}{ll}0.08 \\
\end{array}$ & \multirow{3}{*}{$\begin{array}{c}{[\mathrm{HgT}]} \\
\left(\mu \mathrm{g} \mathrm{g}^{-1}\right)\end{array}$} & 0.88 & 0.22 & -0.21 & 0.38 & -0.52 & 0.50 & 0.09 & -0.08 \\
\hline & $\mathrm{P}$ & 4.E-86 & 2.E-01 & 8.E-02 & 4.E-02 & 1.E-03 & 2.E-03 & 6.E-01 & 7.E-01 & & 2.E-12 & 2.E-01 & 2.E-01 & 2.E-02 & 1.E-03 & 2.E-03 & 6.E-01 & 7.E-01 \\
\hline & $\mathrm{N}$ & 37 & 37 & 37 & 37 & 37 & 37 & 37 & 37 & & 35 & 35 & 37 & 37 & 37 & 37 & 37 & 37 \\
\hline \multirow{3}{*}{$\begin{array}{l}{[\mathrm{Hg}]_{\mathrm{HCl}}} \\
\left(\mu \mathrm{g} \mathrm{g}^{-1}\right)\end{array}$} & CC & & 0.22 & -0.30 & - 0.35 & 0.52 & 0.50 & 0.09 & -0.08 & \multirow{3}{*}{$\begin{array}{l}{[\mathrm{Hg}]_{\mathrm{KoH}}} \\
\left(\mu \mathrm{g} \mathrm{g}^{-1}\right)\end{array}$} & & 0.55 & -0.20 & 0.29 & -0.46 & 0.52 & 0.27 & 0.25 \\
\hline & $\mathrm{P}$ & & 2.E-01 & 8.E-02 & 4.E-02 & 1.E-03 & 2.E-03 & 6.E-01 & 7.E-01 & & & 7.E-04 & 3.E-01 & 9.E-02 & 6.E-03 & 1.E-03 & 1.E-01 & 1.E-01 \\
\hline & $\mathrm{N}$ & & 37 & 37 & 37 & 37 & 37 & 37 & 37 & & & 35 & 35 & 35 & 35 & 35 & 35 & 35 \\
\hline \multirow{3}{*}{$\begin{array}{c}(\mathrm{Hg})_{\mathrm{HCl}} \\
(\%)\end{array}$} & $\mathrm{CC}$ & & & -0.50 & - 0.80 & 0.14 & 0.22 & 0.21 & 0.19 & \multirow{3}{*}{$\begin{array}{c}(\mathrm{Hg})_{\text {кон }} \\
(\%)\end{array}$} & & & 0.01 & 0.18 & -0.04 & 0.26 & 0.40 & 0.34 \\
\hline & $P$ & & & 2.E-03 & 3.E-09 & 4.E-01 & 2.E-01 & 2.E-01 & 3.E-01 & & & & 9.E-01 & 3.E-01 & 8.E-01 & 1.E-01 & 2.E-02 & 4.E-02 \\
\hline & $\mathrm{N}$ & & & 37 & 37 & 37 & 37 & 37 & 37 & & & & 35 & 35 & 35 & 35 & 35 & 35 \\
\hline \multirow{3}{*}{$\begin{array}{l}{[\mathrm{Fe}]_{\mathrm{HCl}}} \\
\left(\mathrm{mg} \mathrm{g}^{-1}\right)\end{array}$} & CC & & & & 0.86 & 0.37 & -0.32 & 0.14 & -0.08 & \multirow{3}{*}{$\begin{array}{l}{[\mathrm{Fe}]_{\mathrm{KOH}}} \\
\left(\mathrm{mg} \mathrm{g}^{-1}\right)\end{array}$} & & & & 0.54 & 0.37 & 0.29 & 0.00 & 0.04 \\
\hline & $\mathrm{P}$ & & & & 8.E-12 & 3.E-02 & 5.E-02 & 4.E-01 & 6.E-01 & & & & & 6.E-04 & 3.E-02 & 8.E-02 & 1. $E+00$ & 8.E-01 \\
\hline & $\mathrm{N}$ & & & & 37 & 37 & 37 & 37 & 37 & & & & & 37 & 37 & 37 & 37 & 37 \\
\hline \multirow{3}{*}{$\begin{array}{c}{[\mathrm{Al}]_{\mathrm{HCl}}} \\
\left(\mathrm{mg} \mathrm{g}^{-1}\right)\end{array}$} & CC & & & & & 0.42 & -0.41 & - 0.11 & - 0.07 & \multirow{3}{*}{$\begin{array}{l}{[\mathrm{Al}]_{\mathrm{KOH}}} \\
\left(\mathrm{mg} \mathrm{g}^{-1}\right)\end{array}$} & & & & & 0.57 & -0.49 & 0.09 & 0.22 \\
\hline & $\mathrm{P}$ & & & & & 1.E-02 & 1.E-02 & 5.E-01 & 7.E-01 & & & & & & 2.E-04 & 2.E-03 & 6.E-01 & 2.E-01 \\
\hline & $\mathrm{N}$ & & & & & 37 & 37 & 37 & 37 & & & & & & 37 & 37 & 37 & 37 \\
\hline \multirow{3}{*}{$\begin{array}{c}\text { Clay } \\
\text { (g/100g) }\end{array}$} & CC & & & & & & -0.85 & 0.05 & 0.09 & \multirow{3}{*}{$\begin{array}{c}\text { Clay } \\
\text { (g/100g) }\end{array}$} & & & & & & -0.85 & 0.05 & 0.09 \\
\hline & $\mathrm{P}$ & & & & & & 4.E-11 & 8.E-01 & 6.E-01 & & & & & & & 4.E-11 & 8.E-01 & 6.E-01 \\
\hline & $\mathrm{N}$ & & & & & & 37 & 37 & 37 & & & & & & & 37 & 37 & 37 \\
\hline \multirow{3}{*}{$\begin{array}{c}\text { Sand } \\
\text { (g/100g) }\end{array}$} & $\mathrm{CC}$ & & & & & & & - 0.38 & -0.41 & \multirow{4}{*}{$\begin{array}{l}\text { Sand } \\
\text { (g/100g) }\end{array}$} & & & & & & & -0.38 & - 0.41 \\
\hline & $\mathrm{P}$ & & & & & & & 2.E-02 & 1.E-02 & & & & & & & & 2.E-02 & 1.E-02 \\
\hline & $\mathrm{N}$ & & & & & & & 37 & 37 & & & & & & & & 37 & 37 \\
\hline \multirow{3}{*}{$\underset{(g / 100 g)}{C}$} & CC & & & & & & & & 0.94 & & & & & & & & & 0.94 \\
\hline & $P$ & & & & & & & & $2.1 \mathrm{E}-18$ & \multirow{2}{*}{$\underset{(g / 100 g)}{C}$} & & & & & & & & 2.E-18 \\
\hline & $\mathrm{N}$ & & & & & & & & 37 & & & & & & & & & 37 \\
\hline
\end{tabular}


Table 2b

\begin{tabular}{|c|c|c|c|c|c|c|c|c|c|c|c|c|c|c|c|c|c|c|}
\hline & $\begin{array}{l}\text { Stati } \\
\text { stics }\end{array}$ & $\begin{array}{l}{[\mathrm{Hg}]_{\text {Asco }}} \\
\left(\mu \mathrm{g} \mathrm{g}^{-1}\right)\end{array}$ & $\begin{array}{c}(\mathrm{Hg})_{\text {Asco }} \\
(\%)\end{array}$ & $\begin{array}{l}{[\mathrm{Fe}]_{\text {Asco }}} \\
\left(\mathrm{mg} \mathrm{g}^{-1}\right)\end{array}$ & $\begin{array}{l}{[A \mathrm{Al}]_{\text {Asco }}} \\
\left(\mathrm{mg} \mathrm{g}^{-1}\right)\end{array}$ & $\begin{array}{c}\text { Clay } \\
(\mathrm{g} / 100 \mathrm{~g})\end{array}$ & $\begin{array}{c}\text { Sand } \\
\text { (g/100g) }\end{array}$ & $\begin{array}{c}C \\
(g / 100 g)\end{array}$ & $\begin{array}{c}S \\
(g / 100 g)\end{array}$ & & $\begin{array}{c}{[\mathrm{Hg}]_{\mathrm{NH} 4 \mathrm{OH}}} \\
\left(\mu \mathrm{g} \mathrm{g}^{-1}\right)\end{array}$ & $\begin{array}{c}(\mathrm{Hg})_{\mathrm{NH} 4 \mathrm{OH}} \\
(\%)\end{array}$ & $\begin{array}{c}{[\mathrm{Fe}]_{\mathrm{NH} 4 \mathrm{OH}}} \\
\left(\mathrm{mg} \mathrm{g}^{-1}\right)\end{array}$ & $\begin{array}{c}{[\mathrm{Al}]_{\mathrm{NH} 4 \mathrm{OH}}} \\
\left(\mathrm{mg} \mathrm{g}^{-1}\right)\end{array}$ & $\begin{array}{c}\text { Clay } \\
\text { (g/100g) }\end{array}$ & $\begin{array}{c}\text { Sand } \\
(\mathrm{g} / 100 \mathrm{~g})\end{array}$ & $\begin{array}{c}C \\
(g / 100 g)\end{array}$ & $\begin{array}{c}S \\
(g / 100 g)\end{array}$ \\
\hline \multirow{3}{*}{$\begin{array}{c}{[\mathrm{HgT}]} \\
\left(\mu \mathrm{g} \mathrm{g}^{-1}\right)\end{array}$} & $\mathrm{CC}$ & 0.89 & -0.23 & -0.27 & -0.40 & -0.52 & 0.50 & -0.09 & $\begin{array}{ll}- & 0.08\end{array}$ & \multirow{3}{*}{$\begin{array}{c}{[\mathrm{HgT}]} \\
\left(\mu \mathrm{g} \mathrm{g}^{-1}\right)\end{array}$} & 0.96 & 0.10 & $\begin{array}{ll}- & 0.15\end{array}$ & $\begin{array}{ll}- & 0.27\end{array}$ & -0.52 & 0.50 & -0.09 & -0.08 \\
\hline & $\mathrm{P}$ & 1.E-13 & 2.E-01 & 1.E-01 & 2.E-02 & 1.E-03 & 2.E-03 & 6.E-01 & 7.E-01 & & 7.E-21 & 5.E-01 & 4.E-01 & 1.E-01 & 1.E-03 & 2.E-03 & 6.E-01 & 7.E-01 \\
\hline & $\mathrm{N}$ & 37 & 37 & 36 & 36 & 37 & 37 & 37 & 37 & & 37 & 37 & 37 & 37 & 37 & 37 & 37 & 37 \\
\hline \multirow{3}{*}{$\begin{array}{c}{[\mathrm{Hg}]_{\text {Asco }}} \\
\left(\mu \mathrm{g} \mathrm{g}^{-1}\right)\end{array}$} & CC & & 0.12 & -0.34 & -0.45 & -0.53 & 0.48 & 0.04 & 0.02 & \multirow{3}{*}{$\begin{array}{c}{[\mathrm{Hg}]_{\mathrm{NH} 4 \mathrm{OH}}} \\
\left(\mu \mathrm{g} \mathrm{g}^{-1}\right)\end{array}$} & & 0.31 & $\begin{array}{ll}- & 0.18\end{array}$ & -0.25 & -0.50 & 0.53 & -0.15 & -0.13 \\
\hline & $\mathrm{P}$ & & 5.E-01 & 4.E-02 & 6.E-03 & 8.E-04 & 3.E-03 & 8.E-01 & 9.E-01 & & & 6.E-02 & 3.E-01 & 1.E-01 & 1.E-03 & 8.E-04 & 4.E-01 & 4.E-01 \\
\hline & $\mathrm{N}$ & & 37 & 36 & 36 & 37 & 37 & 37 & 37 & & & 37 & 37 & 37 & 37 & 37 & 37 & 37 \\
\hline \multirow{3}{*}{$\begin{array}{c}(\mathrm{Hg})_{\text {Asco }} \\
(\%)\end{array}$} & $\mathrm{CC}$ & & & -0.26 & -0.00 & 0.25 & - $\quad 0.25$ & 0.39 & 0.35 & \multirow{3}{*}{$\begin{array}{c}(\mathrm{Hg})_{\mathrm{NH} 4 \mathrm{OH}} \\
(\%)\end{array}$} & & & $\begin{array}{l}-\quad 0.08\end{array}$ & 0.14 & - 0.02 & 0.18 & -0.13 & - 0.05 \\
\hline & $\mathrm{P}$ & & & 1.E-01 & 1. $E+00$ & 1.E-01 & 1.E-01 & 2.E-02 & 3.E-02 & & & & 7.E-01 & 4.E-01 & 9.E-01 & 3.E-01 & 5.E-01 & 8.E-01 \\
\hline & $N$ & & & 36 & 36 & 37 & 37 & 37 & 37 & & & & 37 & 37 & 37 & 37 & 37 & 37 \\
\hline \multirow{3}{*}{$\begin{array}{l}{[\mathrm{Fe}]_{\text {Asco }}} \\
\left(\mathrm{mg} \mathrm{g}^{-1}\right)\end{array}$} & $\mathrm{CC}$ & & & & 0.85 & 0.30 & $-\quad 0.32$ & - 0.10 & -0.03 & \multirow{3}{*}{$\begin{array}{c}{[\mathrm{Fe}]_{\mathrm{NH} 4 \mathrm{OH}}} \\
\left(\mathrm{mg} \mathrm{g}^{-1}\right)\end{array}$} & & & & 0.41 & 0.37 & -0.32 & 0.47 & 0.43 \\
\hline & $P$ & & & & 8.E-11 & 8.E-02 & 6.E-02 & $6 . E-01$ & 9.E-01 & & & & & 1.E-02 & 2.E-02 & 5.E-02 & 3.E-03 & 7.E-03 \\
\hline & $N$ & & & & 36 & 36 & 36 & 36 & 36 & & & & & 37 & 37 & 37 & 37 & 37 \\
\hline \multirow{3}{*}{$\begin{array}{l}{[\mathrm{Al}]_{\text {Asco }}} \\
\left(\mathrm{mg} \mathrm{g}^{-1}\right)\end{array}$} & $\mathrm{CC}$ & & & & & 0.56 & -0.53 & 0.06 & 0.17 & \multirow{3}{*}{$\begin{array}{l}{[\mathrm{Al}]_{\mathrm{NH} 4 \mathrm{OH}}} \\
\left(\mathrm{mg} \mathrm{g}^{-1}\right)\end{array}$} & & & & & 0.46 & - 0.44 & 0.23 & 0.33 \\
\hline & $\mathrm{P}$ & & & & & 4.E-04 & 8.E-04 & 7.E-01 & 3.E-01 & & & & & & 4.E-03 & 7.E-03 & 2.E-01 & 5.E-02 \\
\hline & $N$ & & & & & 36 & 36 & 36 & 36 & & & & & & 37 & 37 & 37 & 37 \\
\hline \multirow{3}{*}{$\begin{array}{c}\text { Clay } \\
(\mathrm{g} / 100 \mathrm{~g})\end{array}$} & $\mathrm{CC}$ & & & & & & $-\quad 0.85$ & 0.05 & 0.09 & \multirow{3}{*}{$\begin{array}{c}\text { Clay } \\
\text { (g/100g) }\end{array}$} & & & & & & -0.85 & 0.05 & 0.09 \\
\hline & $\mathrm{P}$ & & & & & & 4.E-11 & 8.E-01 & 6.E-01 & & & & & & & 4.E-11 & 8.E-01 & 6.E-01 \\
\hline & $\mathrm{N}$ & & & & & & 37 & 37 & 37 & & & & & & & 37 & 37 & 37 \\
\hline \multirow{3}{*}{$\begin{array}{c}\text { Sand } \\
(\mathrm{g} / 100 \mathrm{~g})\end{array}$} & $\mathrm{CC}$ & & & & & & & -0.38 & - 0.41 & \multirow{3}{*}{$\begin{array}{c}\text { Sand } \\
(\mathrm{g} / 100 \mathrm{~g})\end{array}$} & & & & & & & -0.38 & - 0.41 \\
\hline & $\mathrm{P}$ & & & & & & & 2.E-02 & 1.E-02 & & & & & & & & 2.E-02 & 1.E-02 \\
\hline & $\mathrm{N}$ & & & & & & & 37 & 37 & & & & & & & & 37 & 37 \\
\hline \multirow{3}{*}{$\begin{array}{c}C \\
(g / 100 g)\end{array}$} & $\mathrm{CC}$ & & & & & & & & 0.94 & \multirow{3}{*}{$C(g / 100 g)$} & & & & & & & & 0.94 \\
\hline & $P$ & & & & & & & & 2.E-18 & & & & & & & & & 2.E-18 \\
\hline & $\mathrm{N}$ & & & & & & & & 37 & & & & & & & & & 37 \\
\hline
\end{tabular}




\section{Figure captions}

Fig. 1: Top left: french Guiana map with the studied site location (closed circle). Right and bottom: detailed map of the studied site, including general watershed scheme with soil sampling locations, and associated legend.

Fig. 2: Evolutions with depth of total $\mathrm{Hg}, \mathrm{C}$ and $\mathrm{C} / \mathrm{N}$ ratio for (a) pristine and (b) contaminated soils. Evolutions with depth of the clay- and sand-size fractions are reported for pristine and contaminated soils, respectively.

Fig. 3: XRD patterns normalized on quartz peak (refer to the text for details) for raw samples, and following ascorbate, $\mathrm{KOH}, \mathrm{NH}_{4} \mathrm{OH}$ and $\mathrm{HCl} / \mathrm{HNO}_{3}$ extractions.

Fig. 4: Top : Evolutions with depth of $\mathrm{Fe}$ and $\mathrm{Al}$ concentrations extracted by ascorbate and corresponding $\mathrm{Al} / \mathrm{Fe}$ ratio. Bottom: same graphs as top, focused on calculated crystalline + residual fraction in pristine soils.

Fig. 5: Evolutions with depth of $(\mathrm{Hg})_{\mathrm{HCl} / \mathrm{HNO} 3},(\mathrm{Hg})_{\mathrm{CR}},(\mathrm{Hg})_{\mathrm{AscO}},(\mathrm{Hg})_{\mathrm{NH} 4 \mathrm{OH}}$, and $(\mathrm{Hg})_{\mathrm{KOH}}$ extraction yield (\%) in pristine soils. Triangles, circles and squares refer to toposequence I, II and III, and white, grey and black filled colours refer to ferralsols, acrisols and gleysols, respectively.

Fig. 6: XRD patterns of nodules from pristine soils I-2 $(10-20 \mathrm{~cm}), \mathrm{I}-2(30-40 \mathrm{~cm})$, and I-2 (180-200cm).

Fig. 7: $\mu \mathrm{XRF}$ mapping of $\mathrm{Si}, \mathrm{K}, \mathrm{Fe}, \mathrm{Au}$ and $\mathrm{Hg}$ of $\mathrm{SL} 6(30-50 \mathrm{~cm})$ sample and counts measured on $\mathrm{La}$ edge fluorescence of $\mathrm{Hg}$ and $\mathrm{Au}$ versus $\mathrm{Ka}$ radiation of $\mathrm{Si}, \mathrm{K}$ and $\mathrm{Fe}$, and comparison on counts measured for $\mathrm{Hg}(\mathrm{Y}$ axis) versus $\mathrm{Au}$ ( $\mathrm{X}$ axis).

Fig. 8: Evolution with depth of $(\mathrm{Hg})_{\mathrm{HClHNO}},(\mathrm{Hg})_{\mathrm{CR}},(\mathrm{Hg})_{\mathrm{Asco}},(\mathrm{Hg})_{\mathrm{NH} 4 \mathrm{OH}},(\mathrm{Hg})_{\mathrm{KOH}}$ and $\left(\mathrm{Hg}^{0}\right)$ pyrolysis extraction yields $(\%)$ in contaminated soils. 


\section{Fig. 1.}

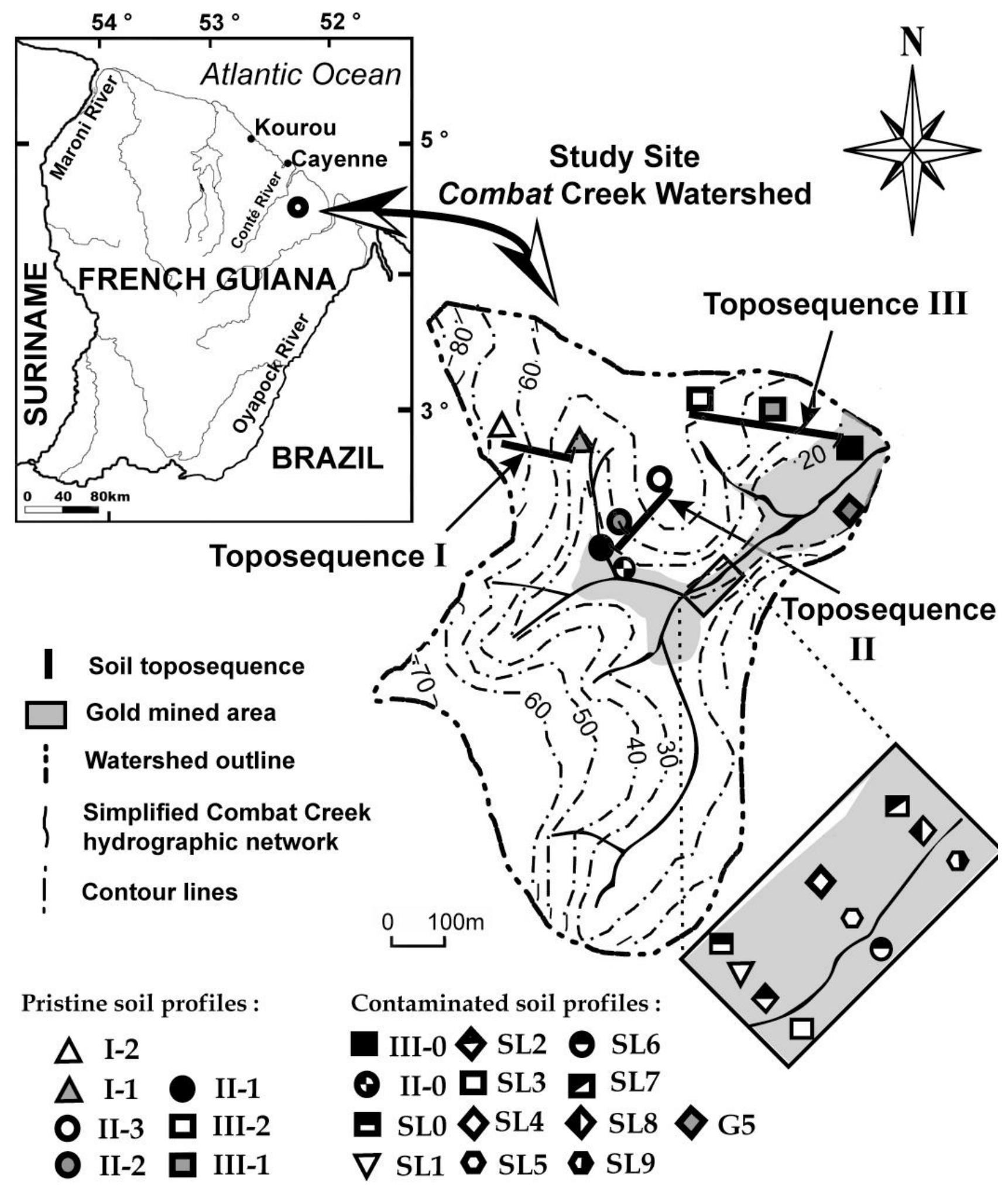


Fig. 2.a.

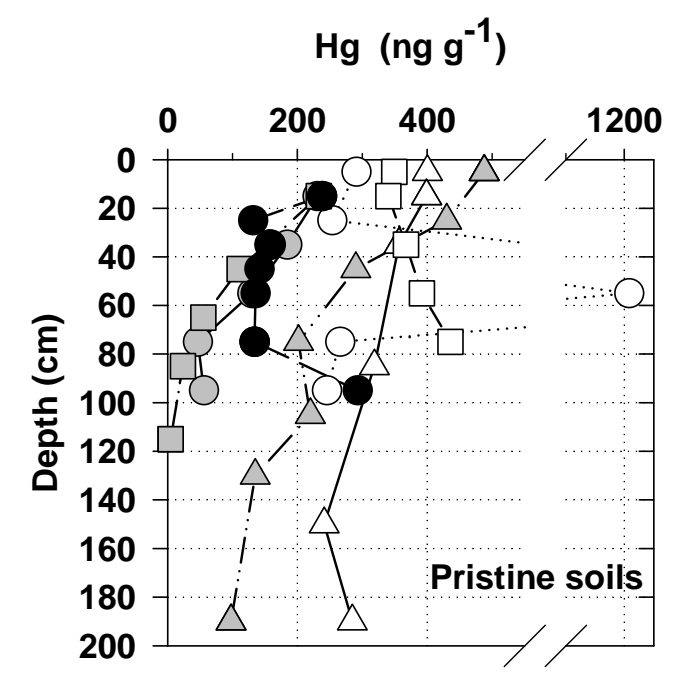

Clay fraction (g/100g) $(<2 \mathrm{~mm})$

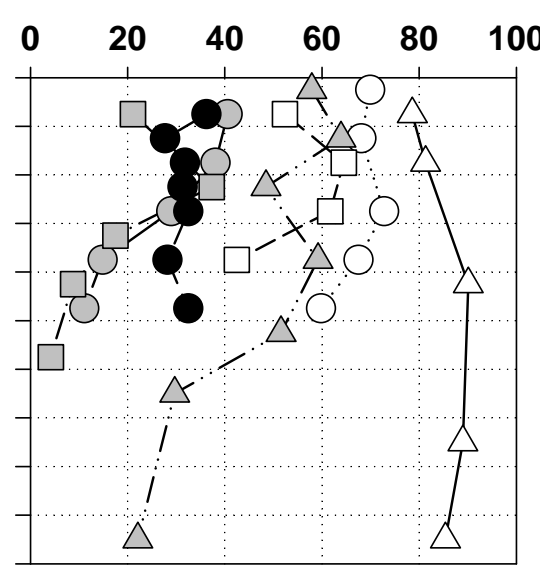

$S$ (g/100g)

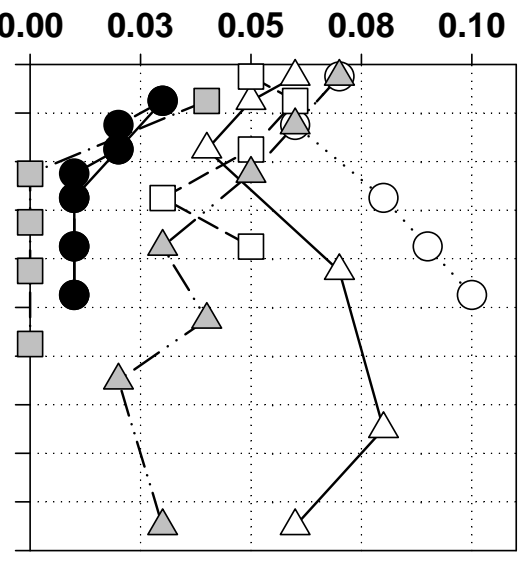

C (g/100g)

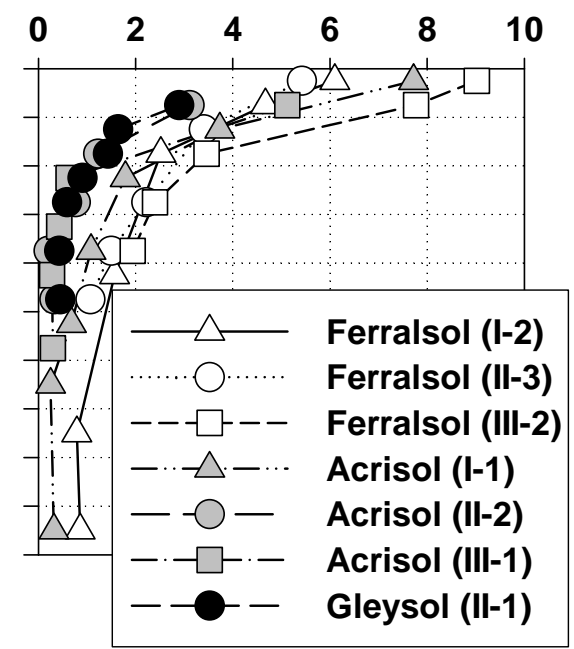


Fig. 2.b.

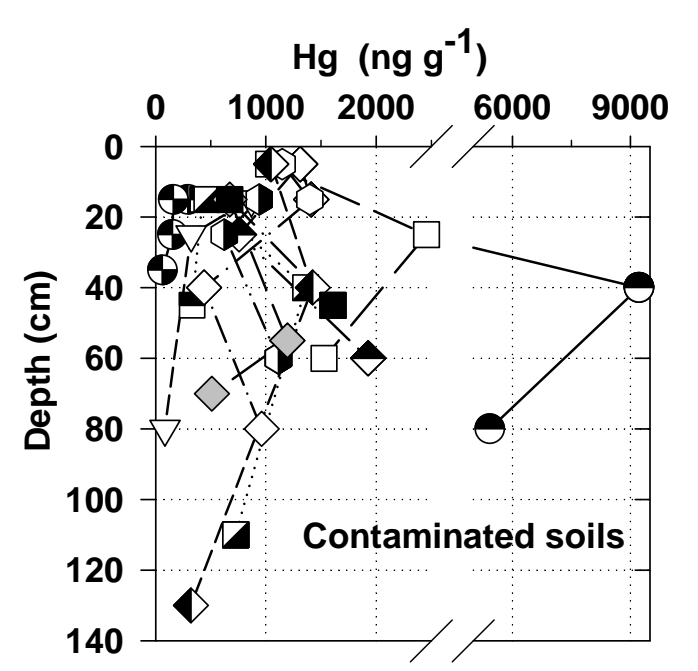

Sand fraction $(\mathrm{g} / 100 \mathrm{~g})(<2 \mathrm{~mm})$

$S$ (g/100g)

C (g/100g)
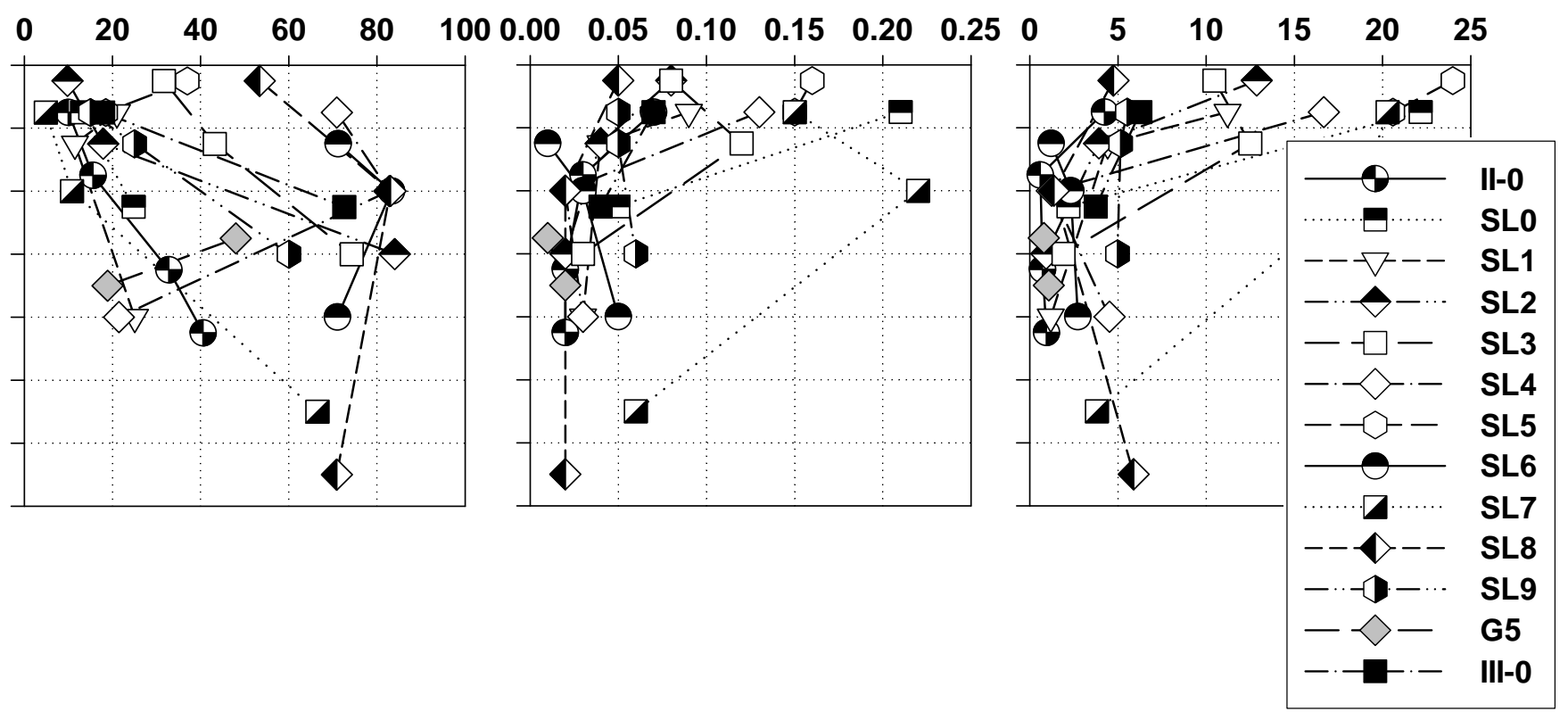
Fig. 3.

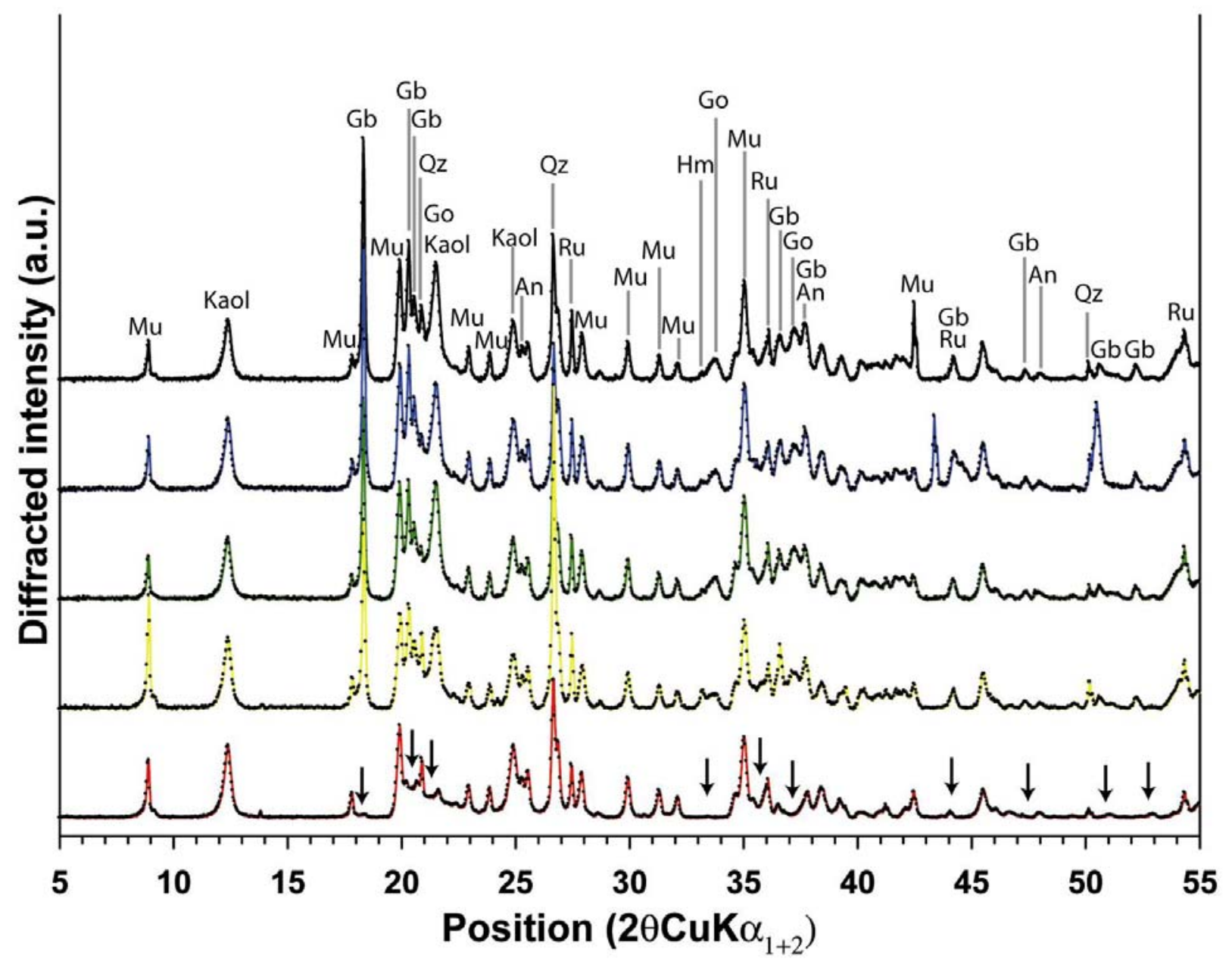


Fig. 4.
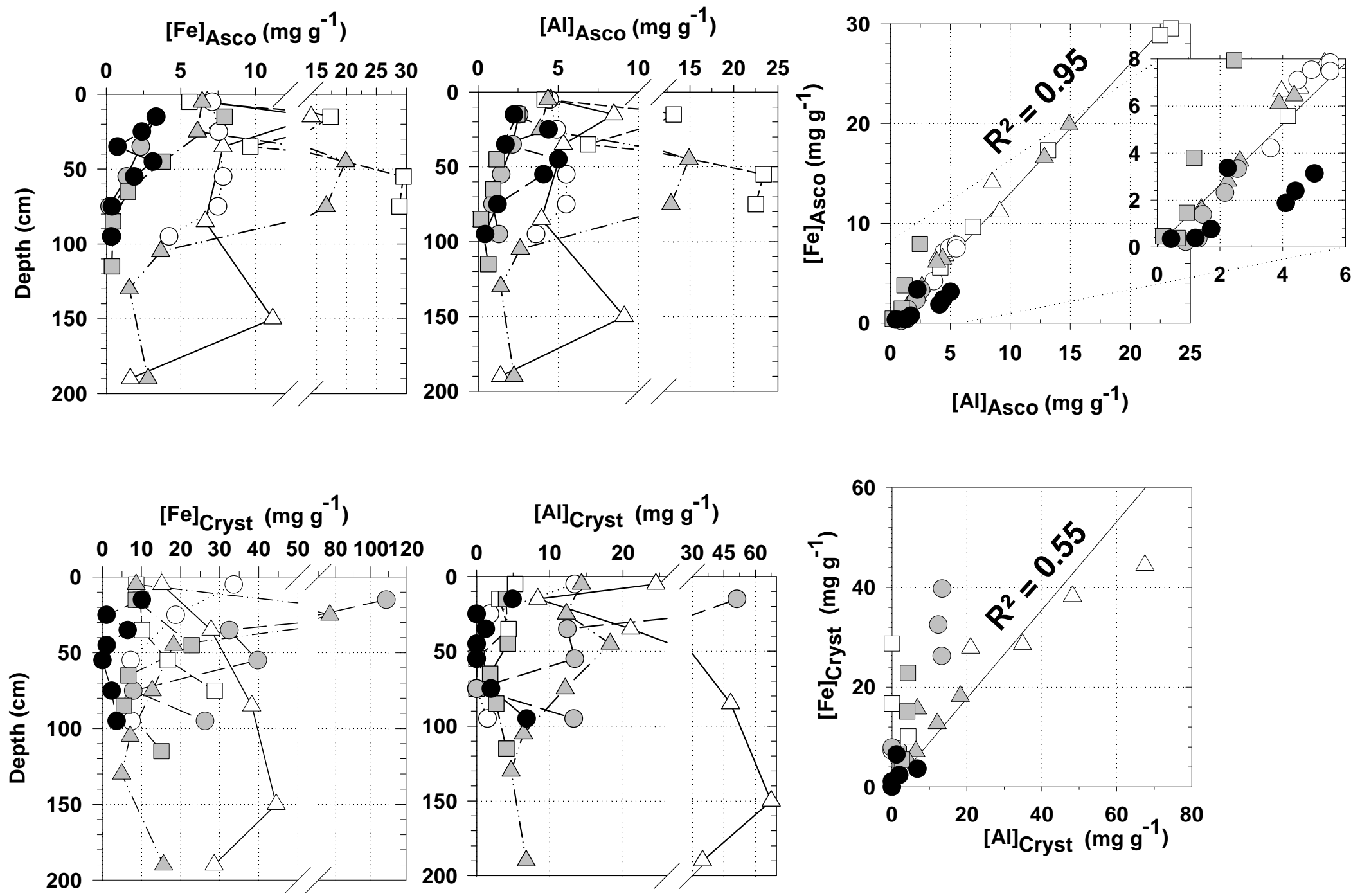
Fig. 5.

$[\mathrm{Hg}]_{\mathrm{HCl} / \mathrm{HNO}_{3}}$ Extraction Yield (\%)

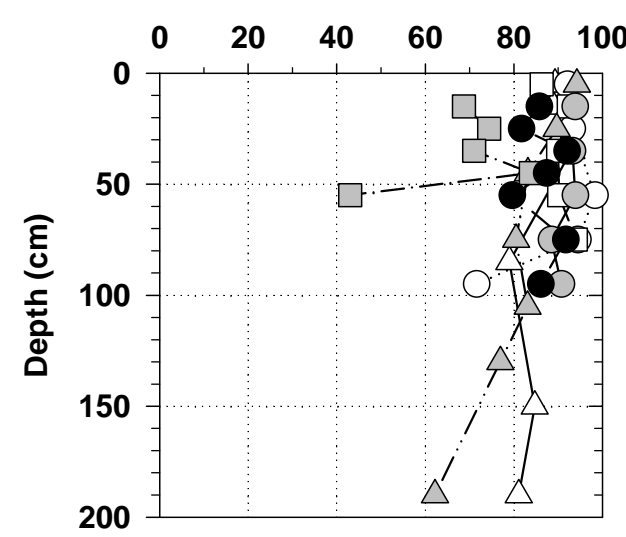

$(\mathrm{Hg})_{\mathrm{NH}_{4} \mathrm{OH}}$ Extraction Yield (\%)

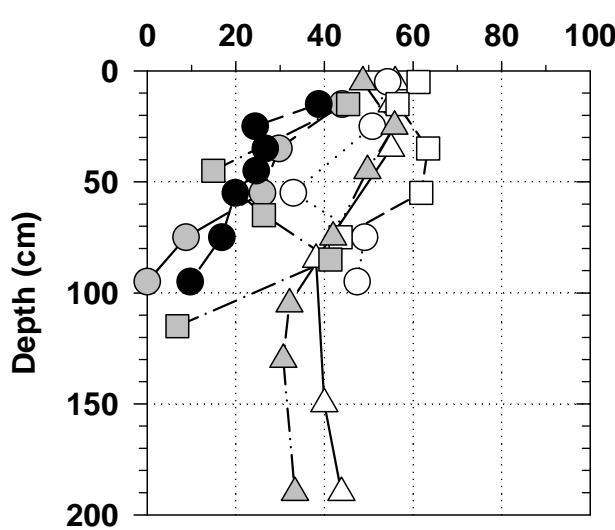

(Hg) CR Extraction Yield (\%)

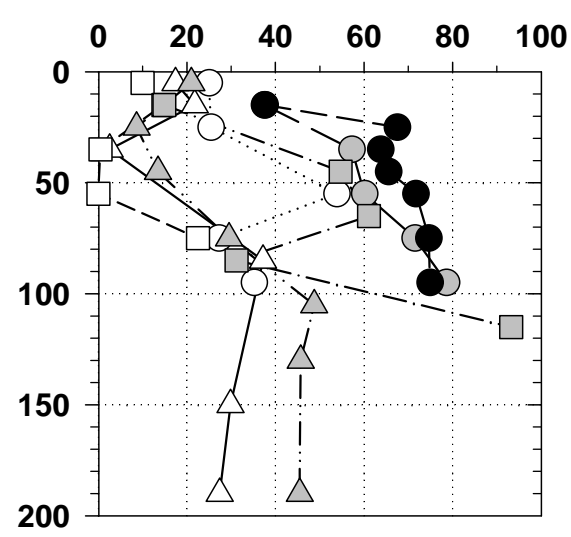

$(\mathrm{Hg})_{\mathrm{KOH}}$ Extraction Yield (\%)

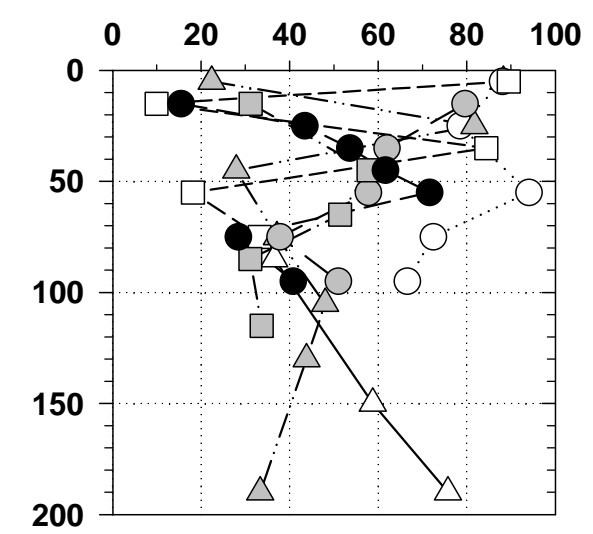

$(\mathrm{Hg})_{\text {Asco }}$ Extraction Yield (\%)

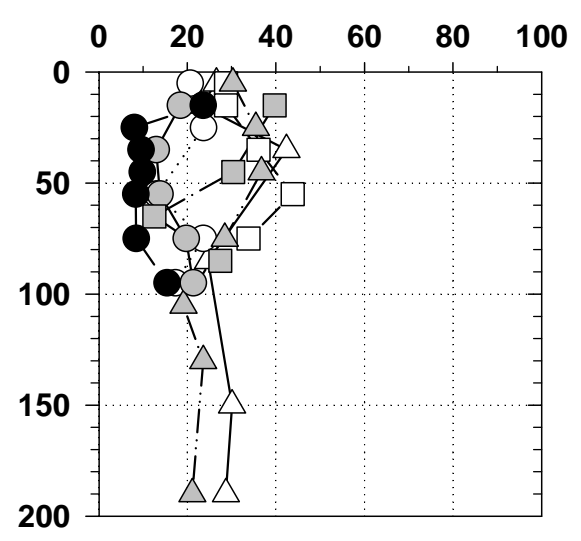


Fig. 6.

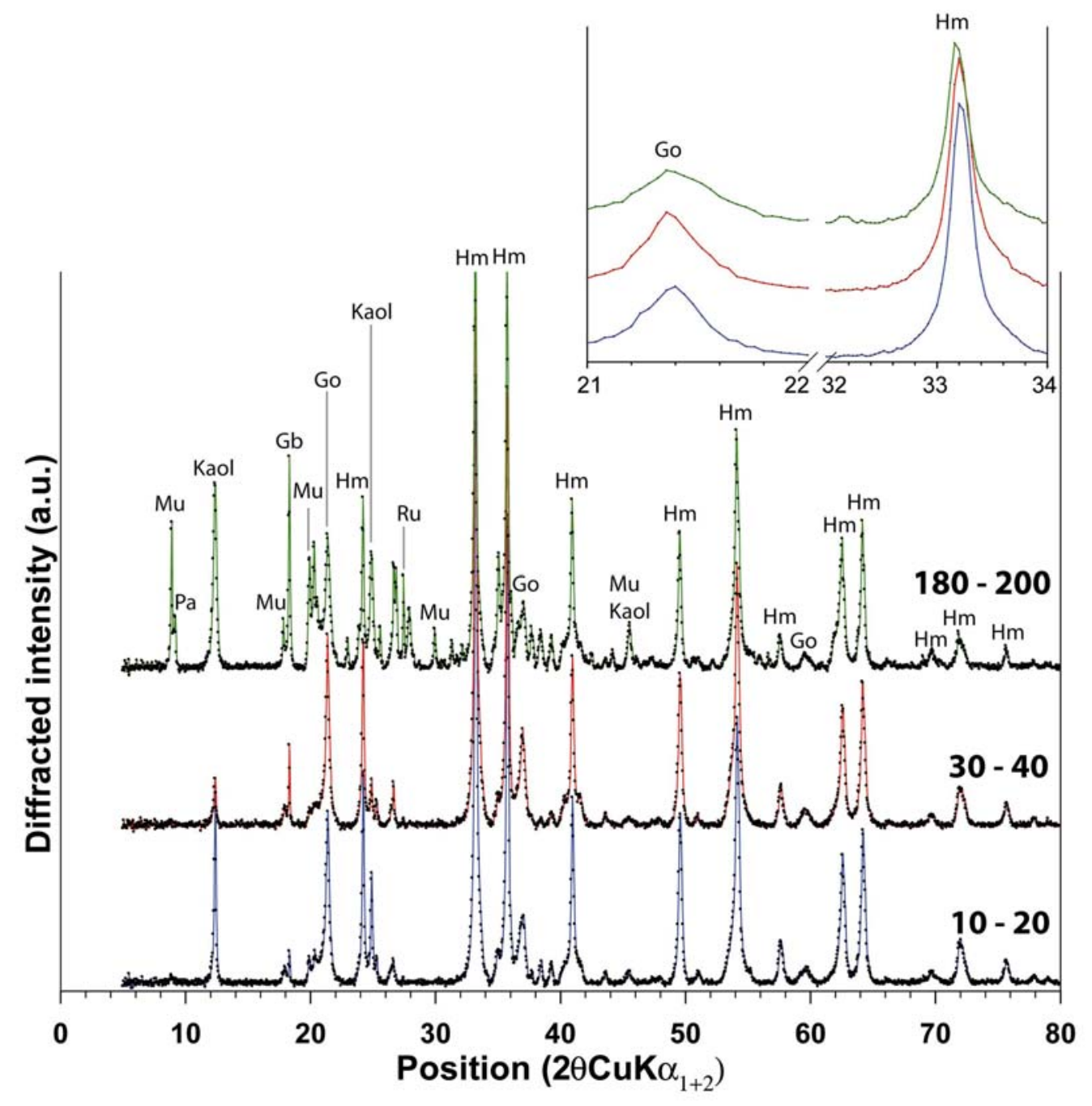


Fig . 7.
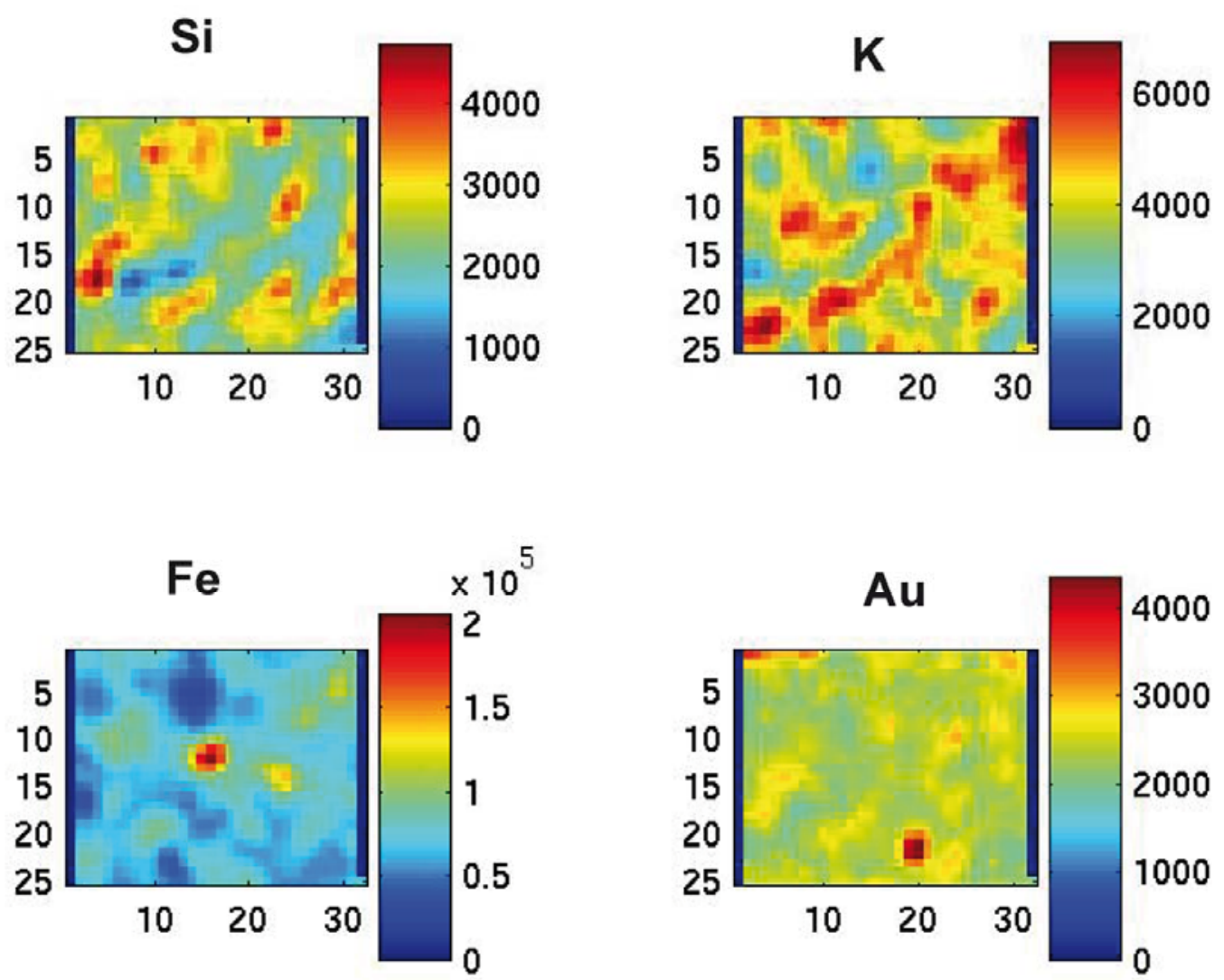

$\mathrm{Hg}$ vs $\mathrm{Au}$
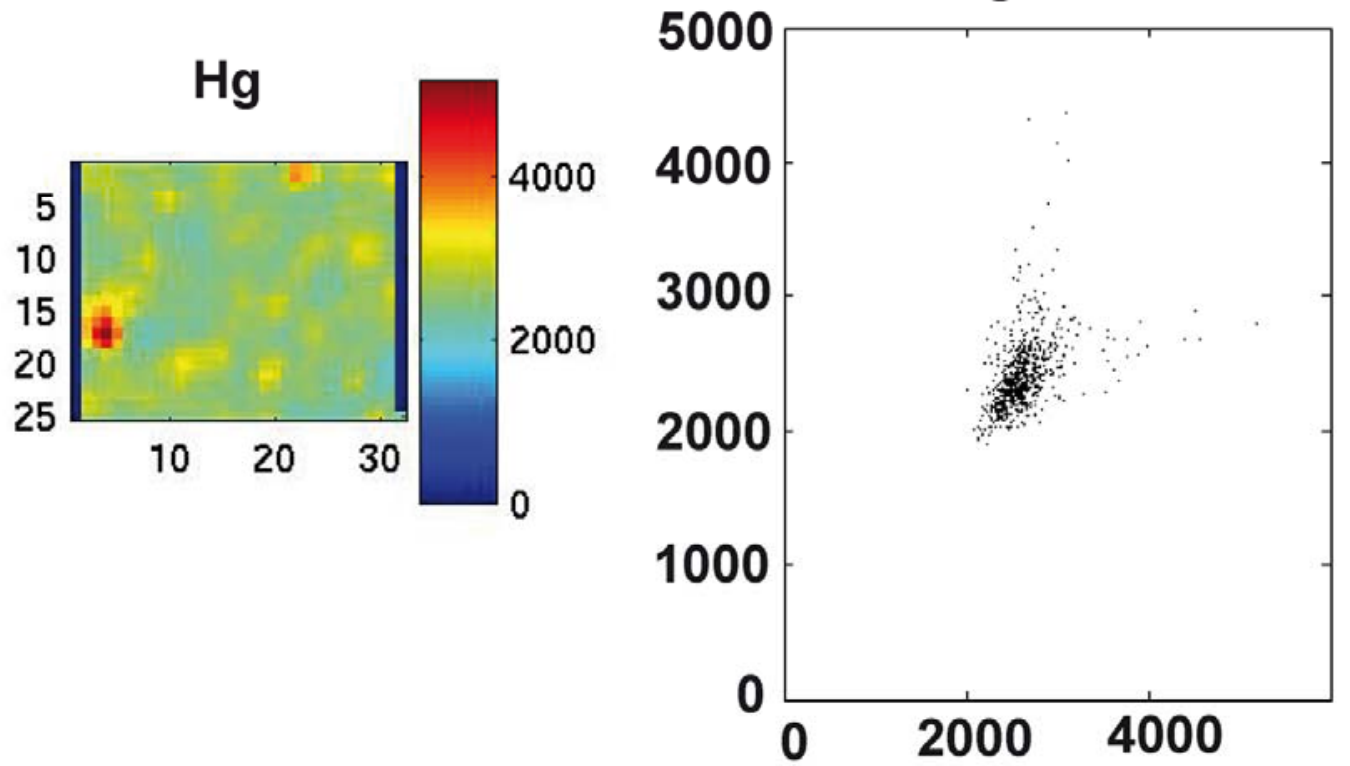
Fig . 8.

$(\mathrm{Hg})_{\mathrm{HCl}}$ Extraction Yield (\%) $\quad(\mathrm{Hg})_{\mathrm{CR}}$ Extraction Yield (\%) $\quad(\mathrm{Hg})_{\text {Asco }}$ Extraction Yield (\%)

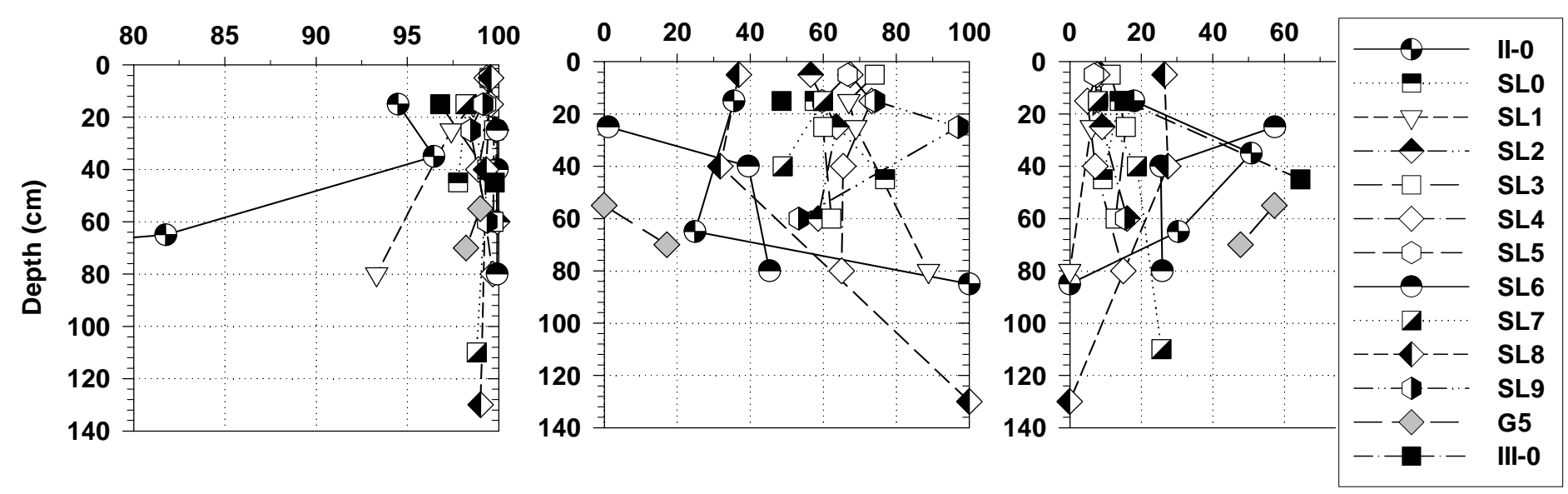

$(\mathrm{Hg})_{\mathrm{NH}_{4} \mathrm{OH}}$ Extraction Yield (\%) $\quad(\mathrm{Hg})_{\mathrm{KOH}}$ Extraction Yield (\%) $\quad$ Pyrolysis extraction yield (\%)

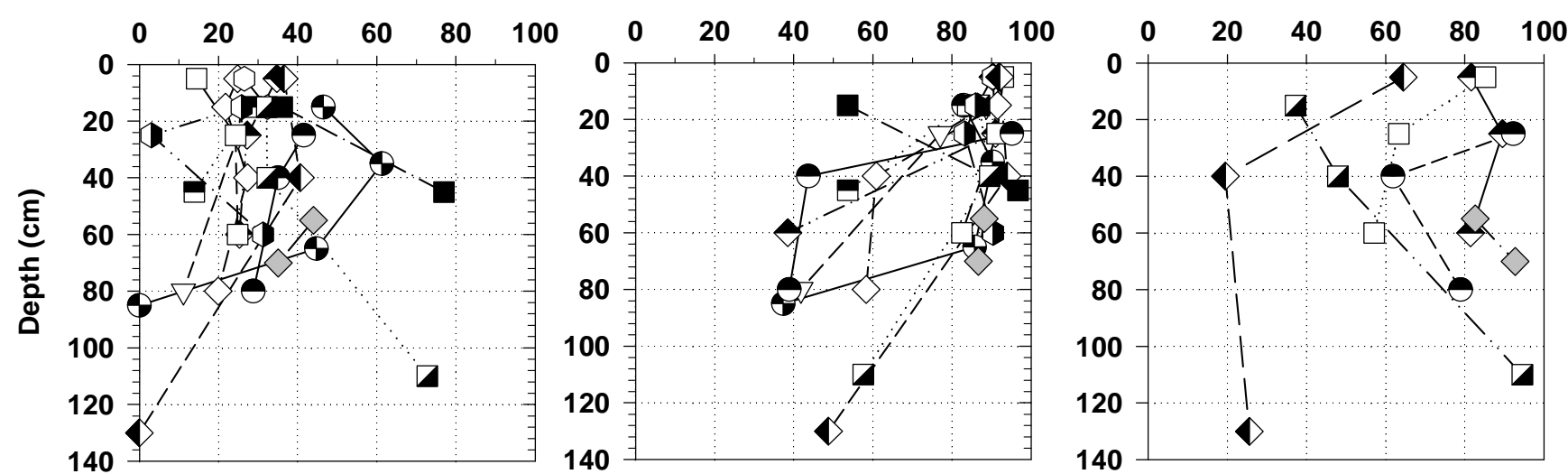




\section{Supplementary data 2}

\section{(Electronic table)}

Table E1: Percent recoveries of $\mathrm{Hg}$ in supernatant and solid residue for Certified materials CRM 7002, MESS-3 and sample I-1 (0$10 \mathrm{~cm}$ ) for ascorbate, $\mathrm{NH}_{4} \mathrm{OH}, \mathrm{KOH}$ and $\mathrm{HCl} / \mathrm{HNO}_{3}$ selective extractions.

\begin{tabular}{|c|c|c|c|c|c|c|c|c|c|c|c|}
\hline & \multicolumn{3}{|c|}{ Ascorbate } & \multicolumn{2}{|c|}{$\mathrm{NH}_{4} \mathrm{OH}$} & \multicolumn{3}{|c|}{$\mathrm{KOH}$} & \multicolumn{3}{|c|}{$\mathrm{HCl} / \mathrm{HNO}_{3}$} \\
\hline Sample & CRM 7002 & MESS- 3 & $\mathrm{I}-1(0-10 \mathrm{~cm})$ & CRM 7002 & MESS- 3 & CRM 7002 & MESS- 3 & $\mathrm{I}-1(0-10 \mathrm{~cm})$ & CRM 7002 & MESS- 3 & $\mathrm{I}-1(0-10 \mathrm{~cm})$ \\
\hline Mean & 98.8 & 68.7 & 60.4 & 102.1 & 93.5 & 106.5 & 96.4 & 87.9 & 101.0 & 114.9 & 109.5 \\
\hline Std. Error & 12.3 & 13.4 & 5.31 & 9.57 & 10.9 & 13.6 & 5.45 & 3.27 & 6.46 & 19.1 & 9.70 \\
\hline Median & 89.9 & 62.9 & 60.4 & 99.0 & 88.2 & 94.5 & 96.5 & 90.4 & 96.7 & 95.6 & 108.5 \\
\hline 0.25 Perc. & 75.5 & 55.6 & 53.5 & 90.3 & 80.4 & 90.5 & 89.3 & 83.7 & 96.7 & 91.0 & 95.7 \\
\hline 0.75 Perc. & 116.2 & 77.8 & 67.3 & 114.8 & 107.9 & 117.8 & 103.5 & 91.5 & 110.7 & 127.6 & 123.3 \\
\hline Size (N) & 6 & 5 & 3 & 3 & 3 & 5 & 3.0 & 3 & 7 & 5 & 4 \\
\hline
\end{tabular}




\section{Supplementary Figure captions}

Fig. E1a: X-ray diffraction pattern of CRM Mess-3 (black trace) showing identified minerals (colored ticks)

Fig. E1b: Normalized X-ray diffraction patterns of CRM Mess-3 before and after $\mathrm{NH}_{4} \mathrm{OH}$ extraction (black and red traces, respectively) showing identified minerals (colored ticks)

Fig. E1c: Normalized X-ray diffraction patterns of CRM Mess-3 before and after $\mathrm{KOH}$ extraction (black and red traces, respectively) showing identified minerals (colored ticks)

Fig. E1d: Normalized X-ray diffraction patterns of CRM Mess-3 before and after ascorbate extraction (black and red traces, respectively) showing identified minerals (colored ticks)

Fig. E1e: Normalized X-ray diffraction patterns of CRM Mess-3 before and after $\mathrm{HCl} / \mathrm{HNO}_{3}$ extraction (black and red traces, respectively) showing identified minerals (colored ticks)

Fig. E2a: X-ray diffraction pattern of CRM 7002 (black trace) showing identified minerals (colored ticks)

Fig. E2b: Normalized X-ray diffraction patterns of CRM 7002 before and after $\mathrm{NH}_{4} \mathrm{OH}$ extraction (black and red traces, respectively) showing identified minerals (colored ticks)

Fig. E2c: Normalized X-ray diffraction patterns of CRM 7002 before and after $\mathrm{KOH}$ extraction (black and red traces, respectively) showing identified minerals (colored ticks) 
Fig. E2d: Normalized X-ray diffraction patterns of CRM 7002 before and after ascorbate extraction (black and red traces, respectively) showing identified minerals (colored ticks)

Fig. E2e: Normalized X-ray diffraction patterns of CRM 7002 before and after $\mathrm{HCl} / \mathrm{HNO}_{3}$ extraction (black and red traces, respectively) showing identified minerals (colored ticks)

Fig. E3a: X-ray diffraction pattern of sample $\mathrm{I}-1(0-10 \mathrm{~m})$ (black trace) showing identified minerals (colored ticks)

Fig. E3b: Normalized X-ray diffraction patterns of sample $1-1(0-10 \mathrm{~m})$ before and after $\mathrm{NH}_{4} \mathrm{OH}$ extraction (black and red traces, respectively) showing identified minerals (colored ticks)

Fig. E3c: Normalized X-ray diffraction patterns of sample $\mathrm{I}-1(0-10 \mathrm{~m})$ before and after $\mathrm{KOH}$ extraction (black and red traces, respectively) showing identified minerals (colored ticks)

Fig. E3d: Normalized X-ray diffraction patterns of sample I-1 $(0-10 \mathrm{~m})$ before and after ascorbate extraction (black and red traces, respectively) showing identified minerals (colored ticks)

Fig. E3e: Normalized X-ray diffraction patterns of sample $\mathrm{I}-1(0-10 \mathrm{~m})$ before and after $\mathrm{HCl} / \mathrm{HNO}_{3}$ extraction (black and red traces, respectively) showing identified minerals (colored ticks)

Fig. E4: X-ray diffraction pattern of nodules from sample I-1(180-200m) (black trace) showing identified minerals (colored ticks)

Fig. E5: Total $\mathrm{Hg},(\mathrm{Hg})_{\mathrm{HCl} / \mathrm{HNO} 3},(\mathrm{Hg})_{\text {residual, }}(\mathrm{Hg})_{\mathrm{Asco}},(\mathrm{Hg})_{\mathrm{NH} 4 \mathrm{OH}}$, and $(\mathrm{Hg})_{\mathrm{KOH}}$ extractions extraction yield (\%) vertical profiles in nodules of pristine soils. Triangles refer to toposequence I, triangles up refers to surface nodules, and 
triangle down to deeper horizons III. white and grey filled colours refer to oxisol and ultisol, respectively. Filled triangles refer to sol matrix and haircrossed symbols refer to nodules. 
Fig. E1a. X-ray diffraction pattern of CRM Mess-3 (black trace) showing identified minerals (colored ticks)

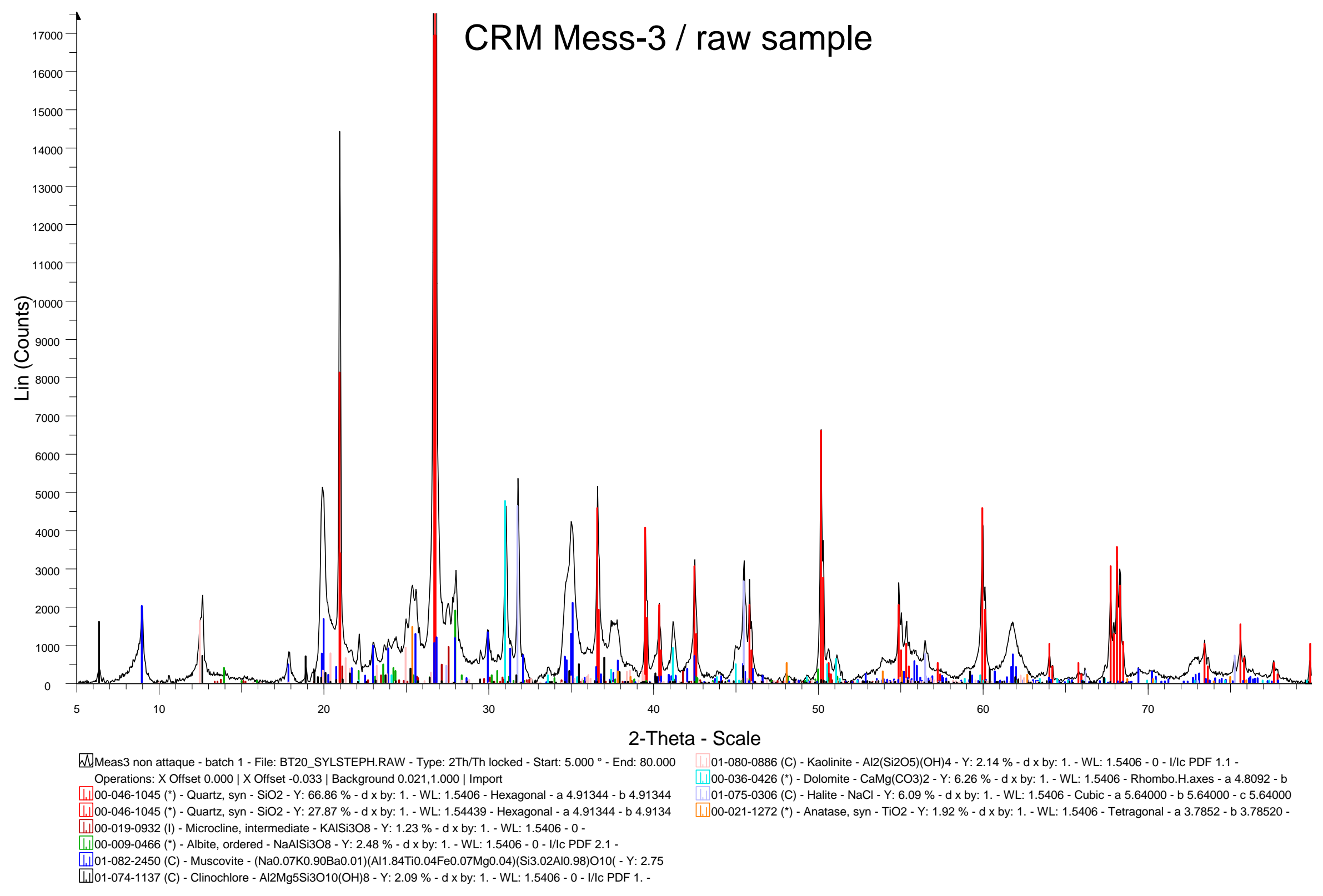


Fig. E1b. Normalized X-ray diffraction patterns of CRM Mess-3 before and after $\mathrm{NH}_{4} \mathrm{OH}$ extraction (black and red traces, respectively) showing identified minerals (colored ticks)

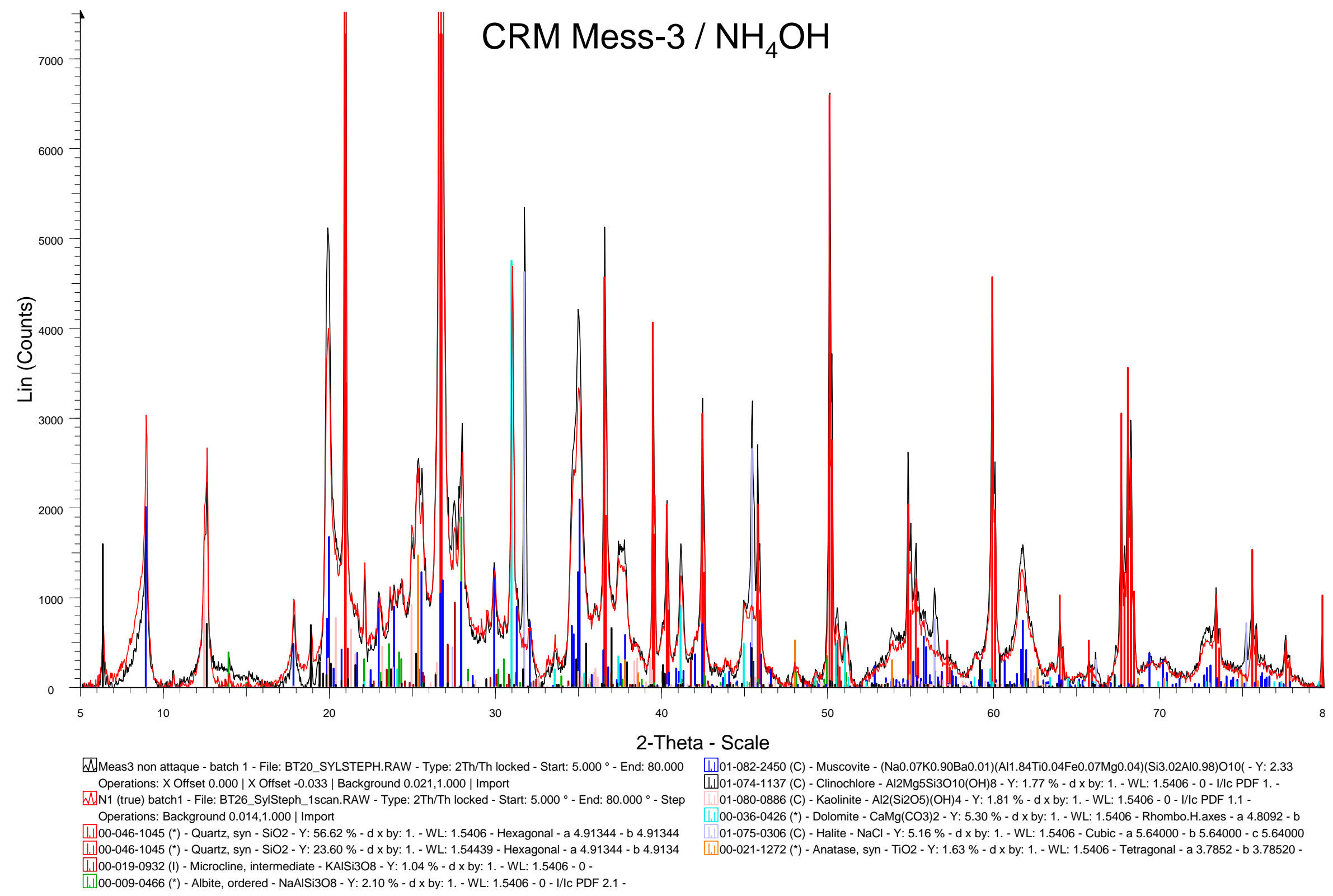


Fig. E1c. Normalized X-ray diffraction patterns of CRM Mess-3 before and after $\mathrm{KOH}$ extraction (black and red traces, respectively) showing identified minerals (colored ticks)

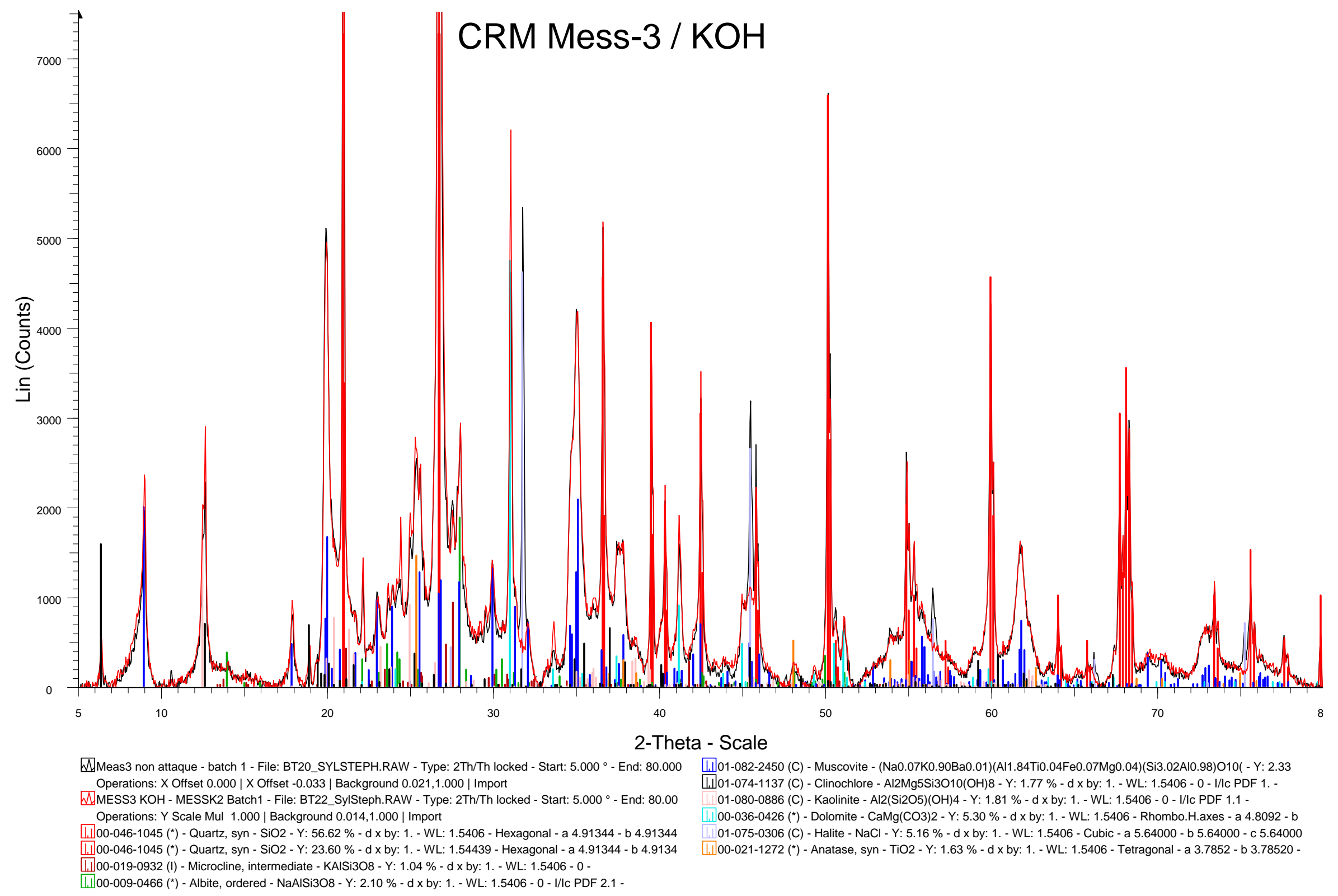


Fig. E1d. Normalized X-ray diffraction patterns of CRM Mess-3 before and after ascorbate extraction (black and red traces, respectively) showing identified minerals (colored ticks)

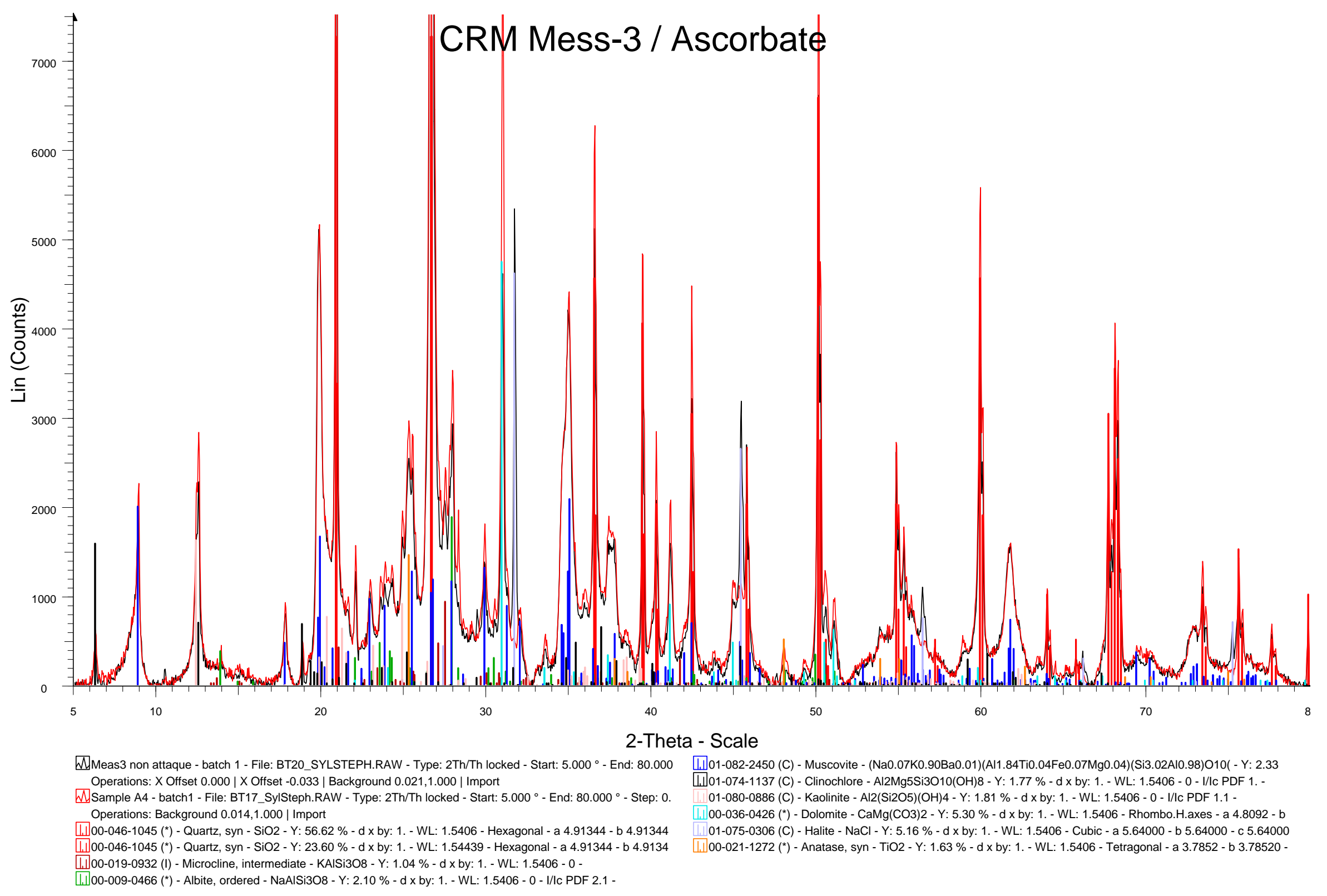


Fig. E1e. Normalized X-ray diffraction patterns of CRM Mess-3 before and after $\mathrm{HCl}$ extraction (black and red traces, respectively) showing identified minerals (colored ticks)

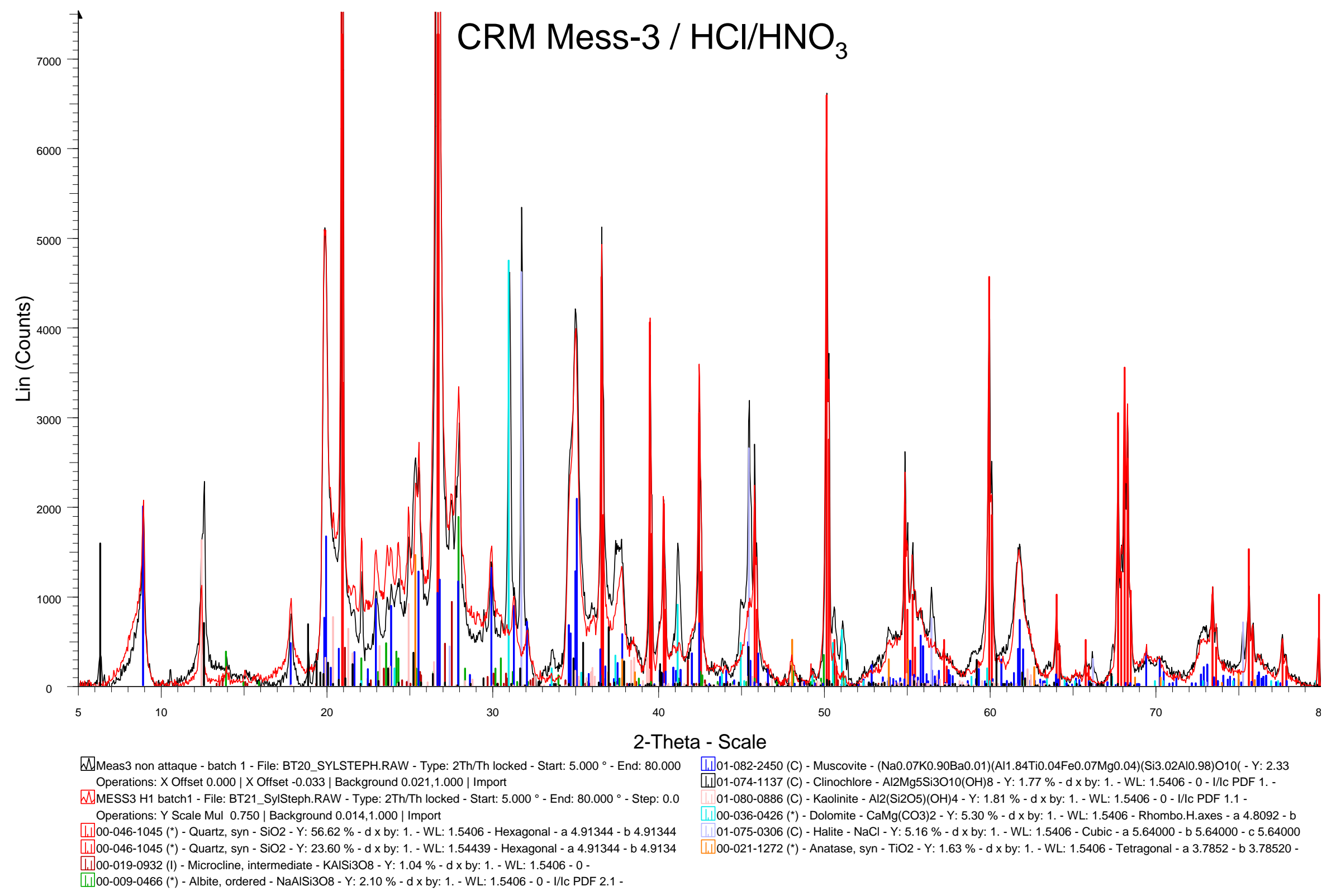


Fig. E2a. X-ray diffraction pattern of CRM 7002 (black trace) showing identified minerals (colored ticks)

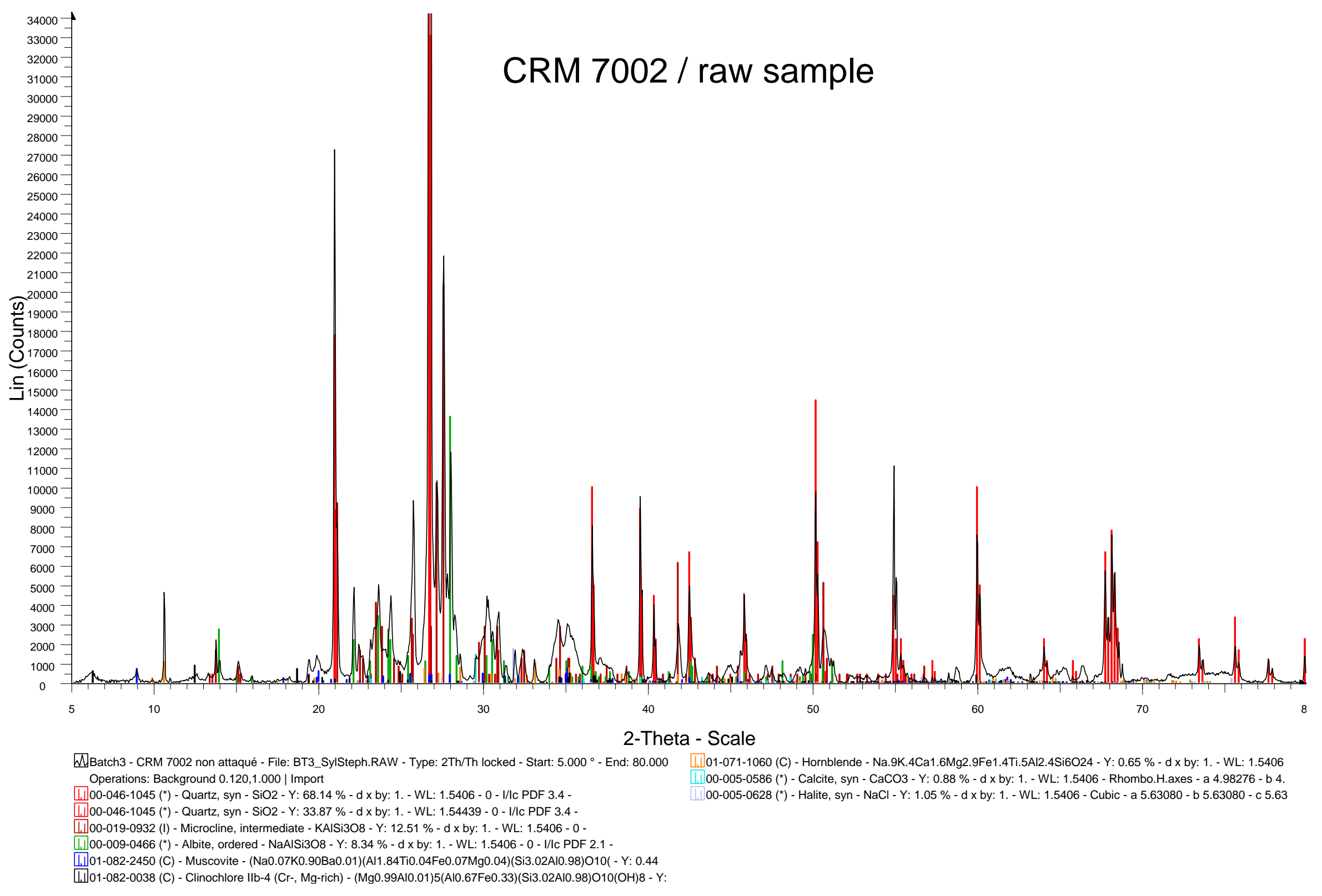


Fig. E2b. Normalized X-ray diffraction patterns of CRM 7002 before and after $\mathrm{NH}_{4} \mathrm{OH}$ extraction (black and red traces, respectively) showing identified minerals (colored ticks)

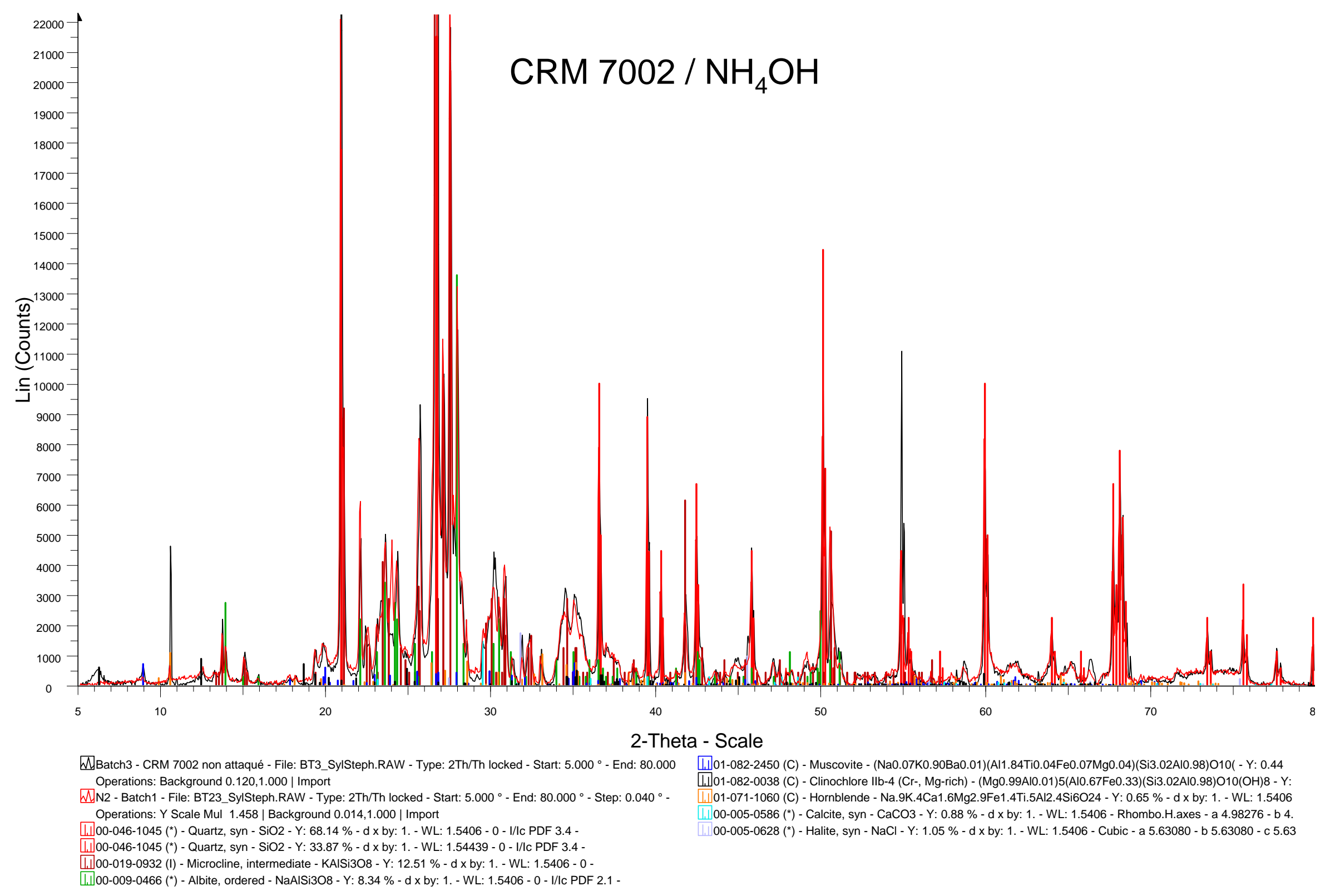


Fig. E2c. Normalized X-ray diffraction patterns of CRM 7002 before and after $\mathrm{KOH}$ extraction (black and red traces, respectively) showing identified minerals (colored ticks)

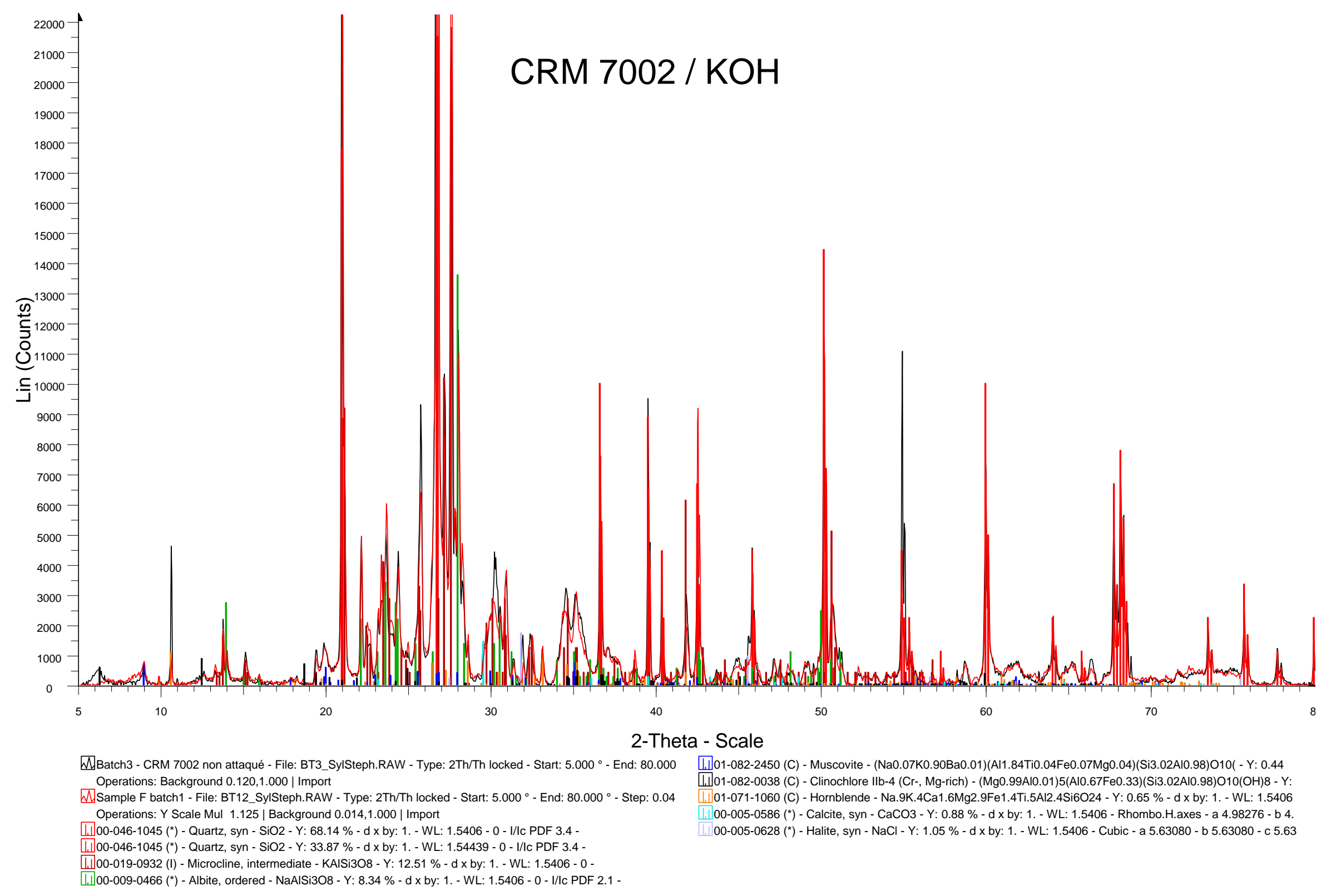


Fig. E2d. Normalized X-ray diffraction patterns of CRM 7002 before and after ascorbate extraction (black and red traces, respectively) showing identified minerals (colored ticks)

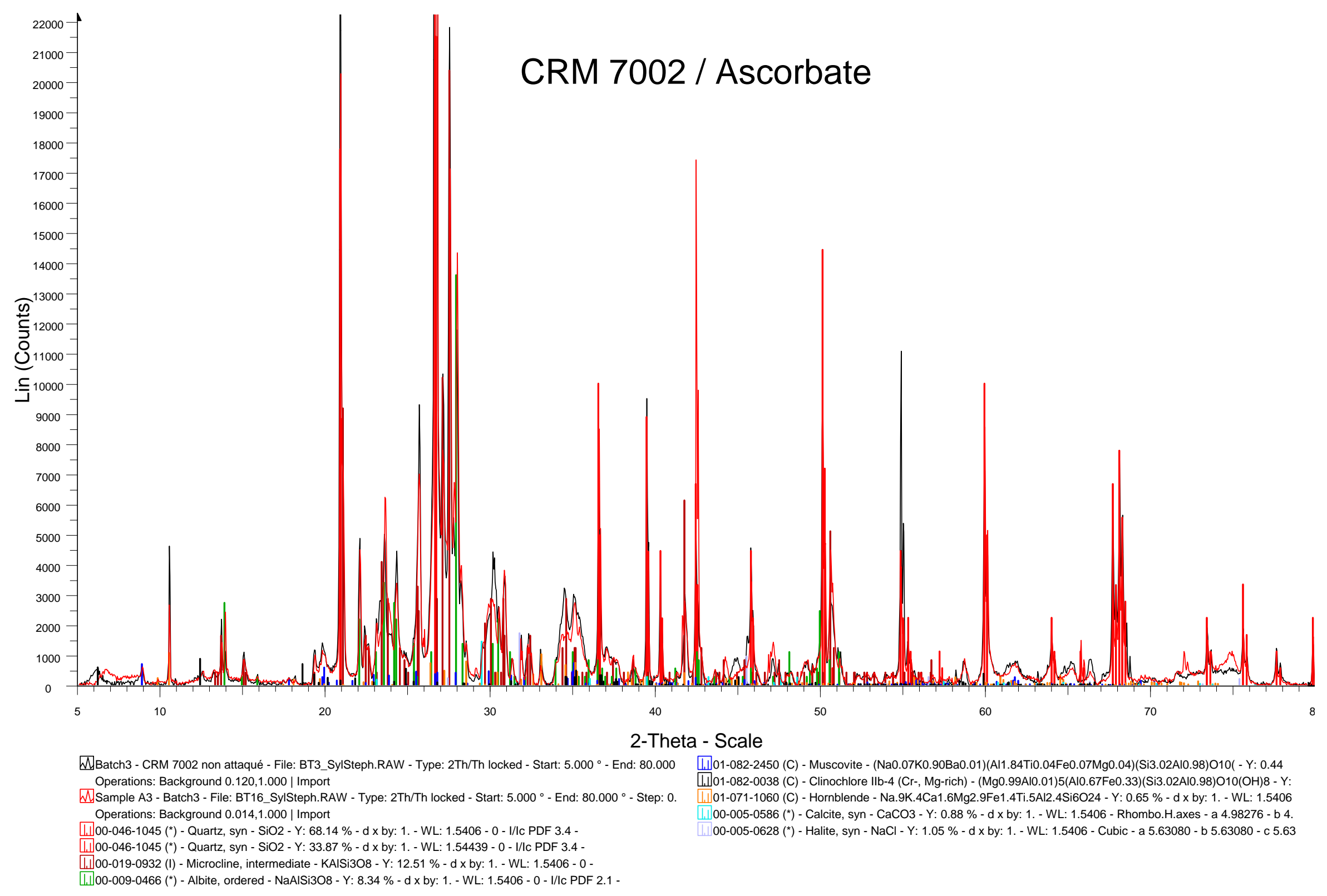


Fig. E2e. Normalized X-ray diffraction patterns of CRM 7002 before and after $\mathrm{HCl}$ extraction (black and red traces, respectively) showing identified minerals (colored ticks)

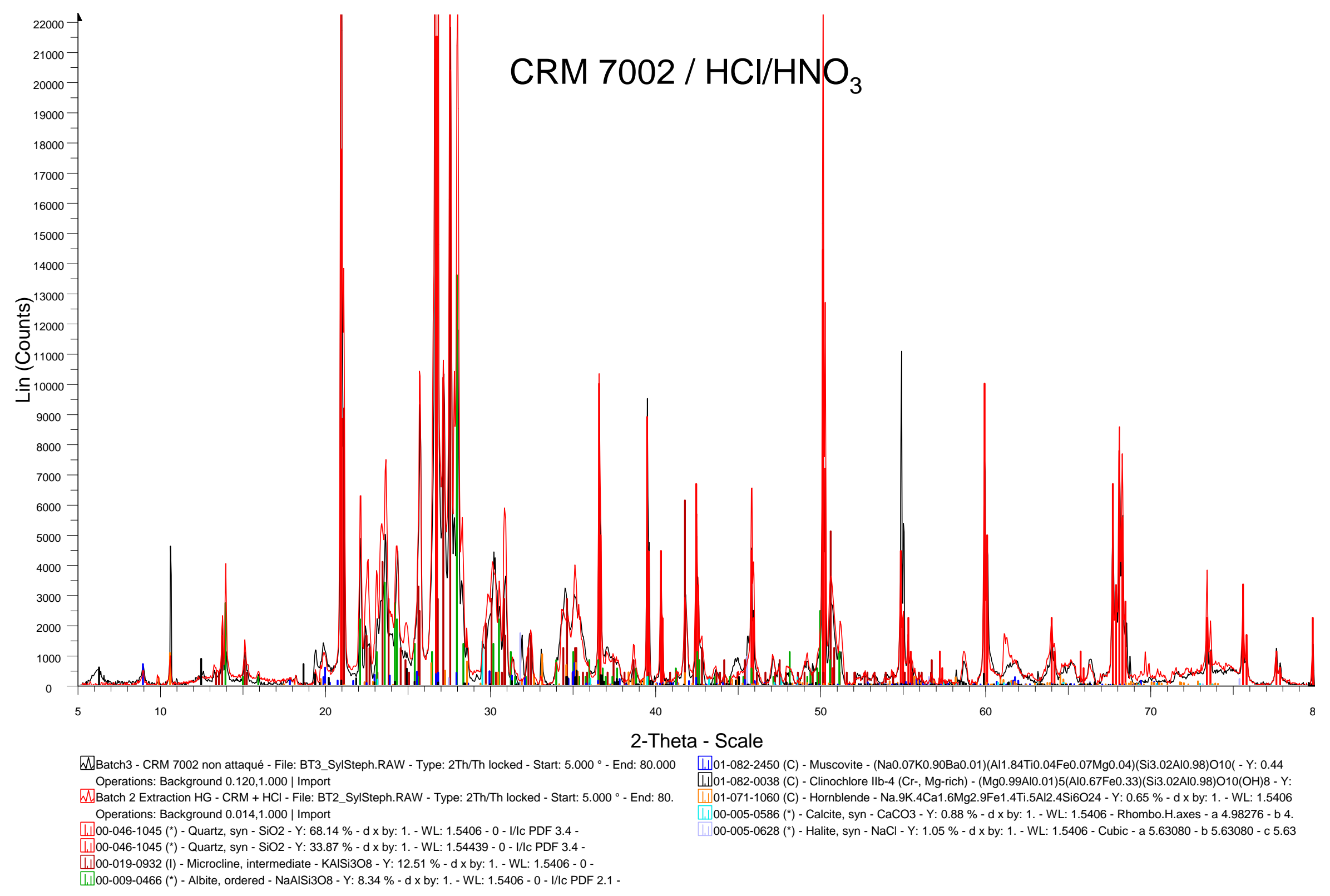


Fig. E3a. X-ray diffraction pattern of sample I-1(0-10m) (black trace) showing identified minerals (colored ticks)

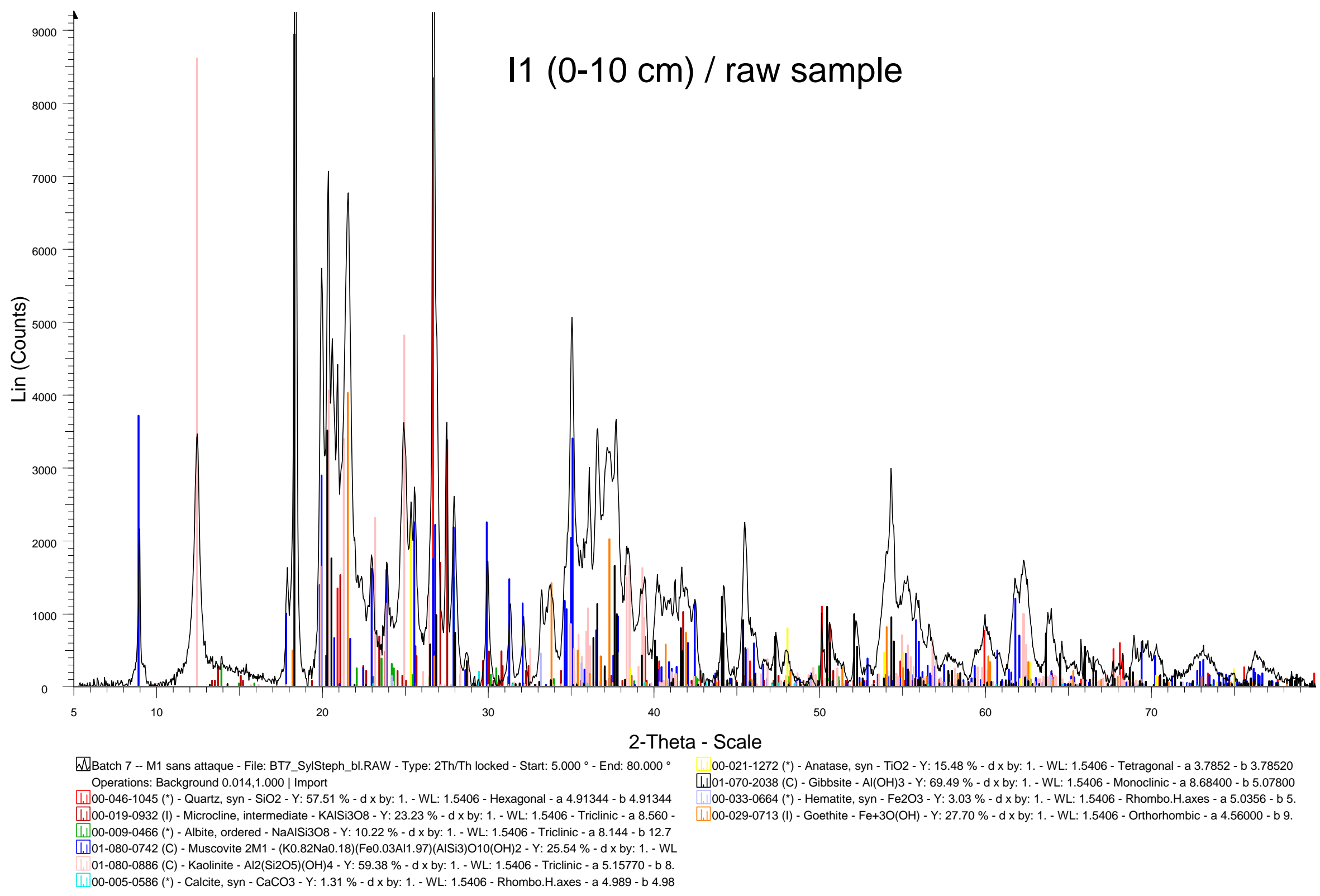


Fig. E3b. Normalized X-ray diffraction patterns of sample I-1(0-10m) before and after $\mathrm{NH}_{4} \mathrm{OH}$ extraction (black and red traces, respectively) showing identified minerals (colored ticks)

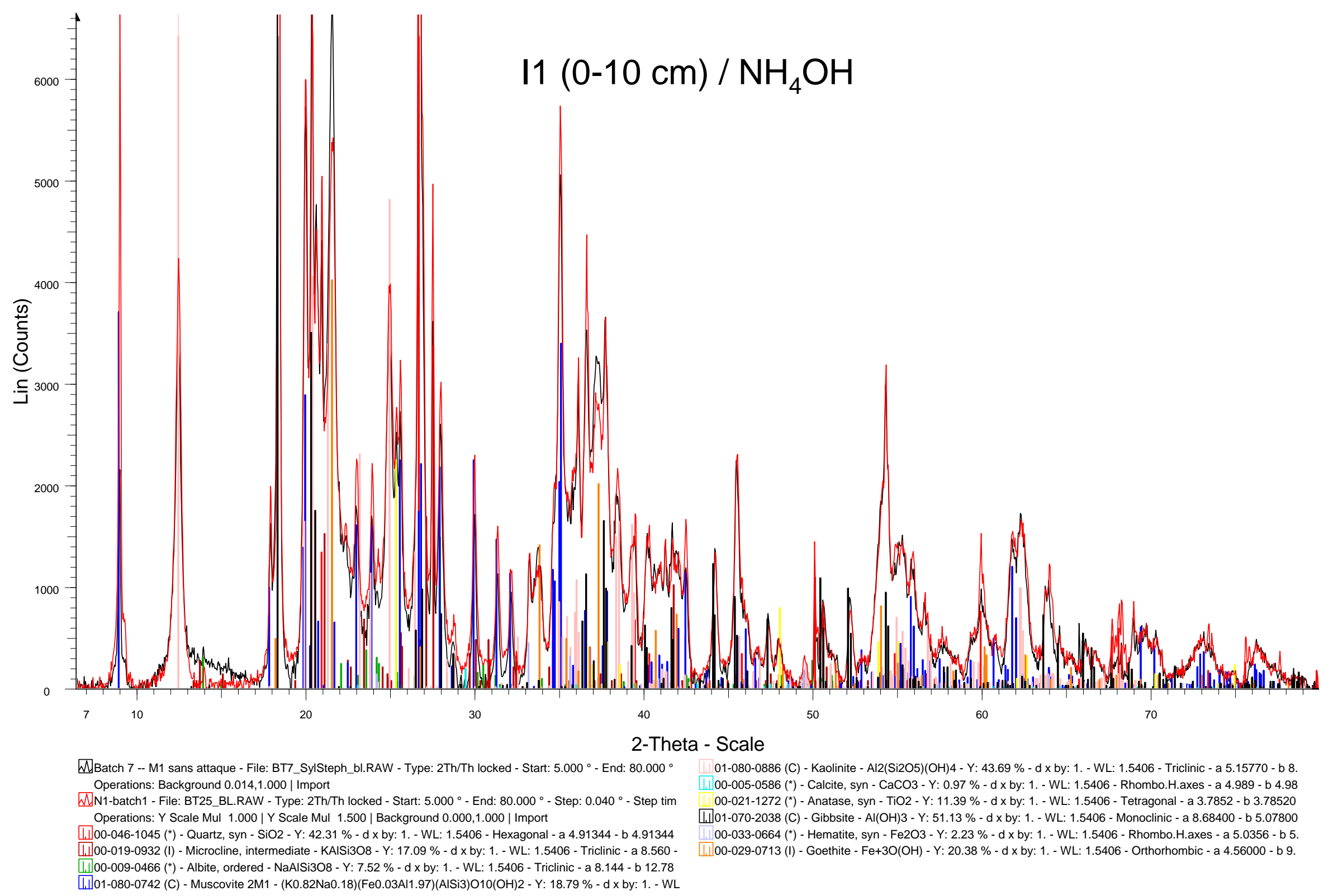


Fig. E3c. Normalized X-ray diffraction patterns of sample $\mathrm{I}-1(0-10 \mathrm{~m})$ before and after $\mathrm{KOH}$ extraction (black and red traces, respectively) showing identified minerals (colored ticks)

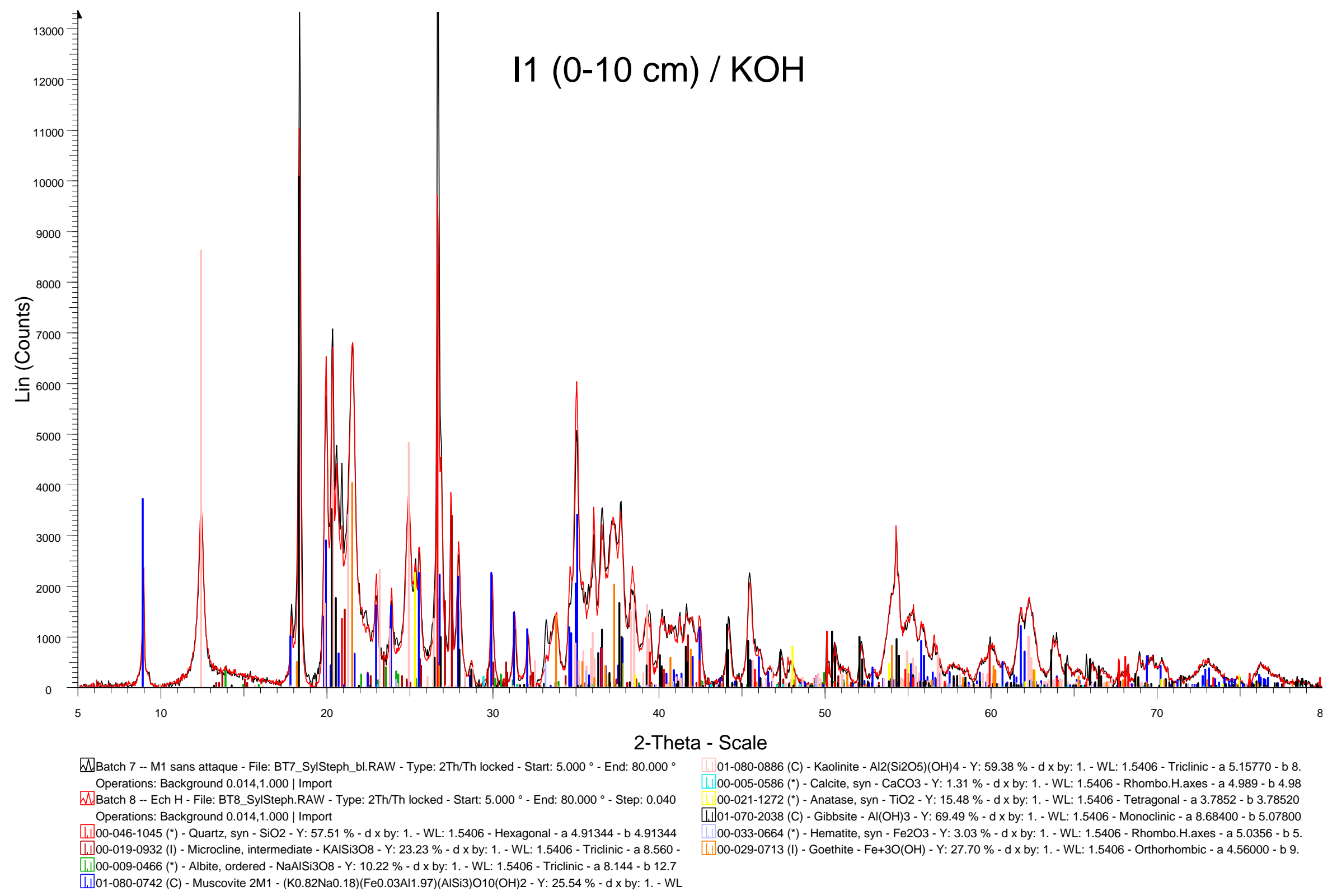


Fig. E3d. Normalized X-ray diffraction patterns of sample I-1(0-10m) before and after ascorbate extraction (black and red traces, respectively) showing identified minerals (colored ticks)

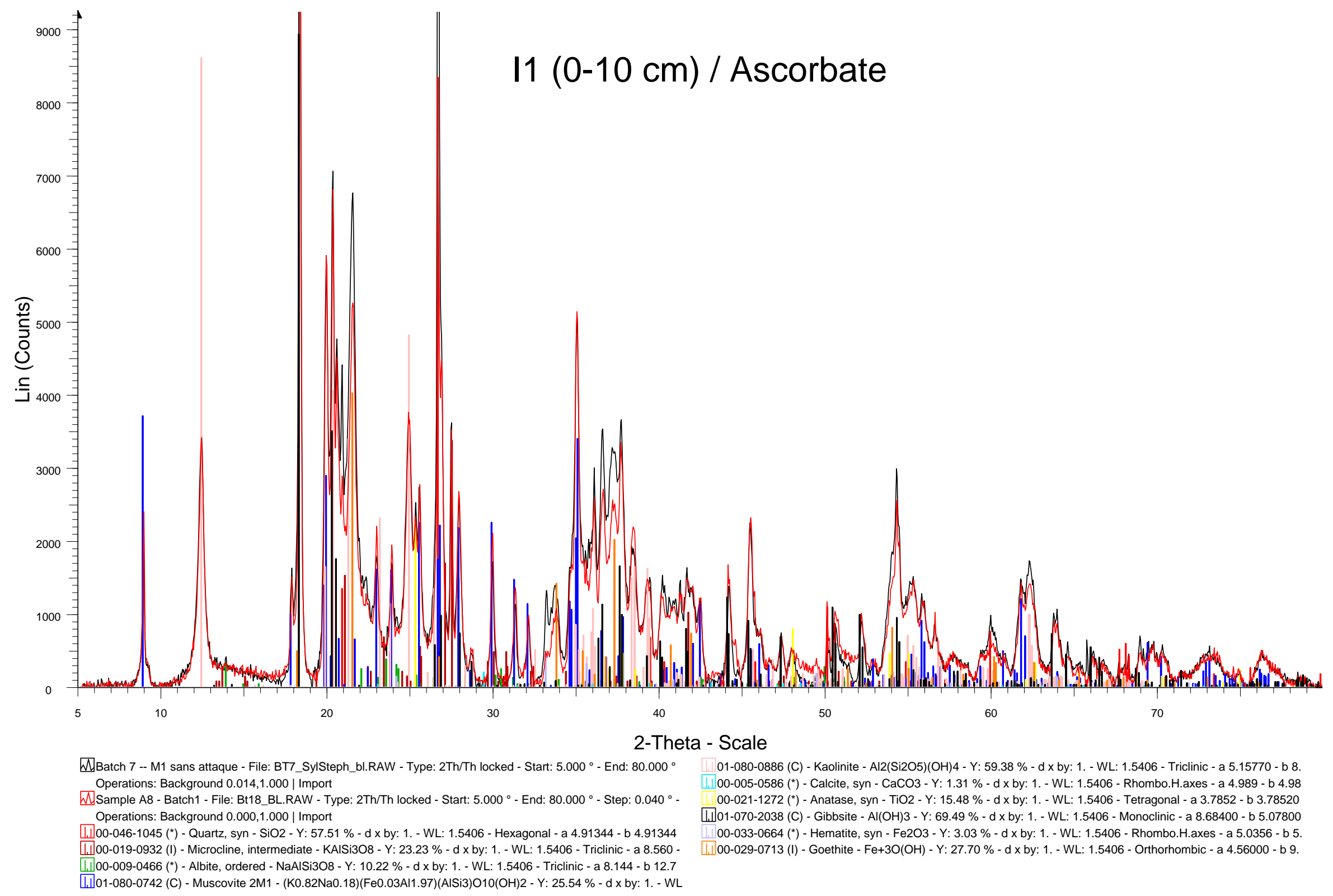


Fig. E3e. Normalized X-ray diffraction patterns of sample I-1(0-10m) before and after $\mathrm{HCl}$ extraction (black and red traces, respectively) showing identified minerals (colored ticks)

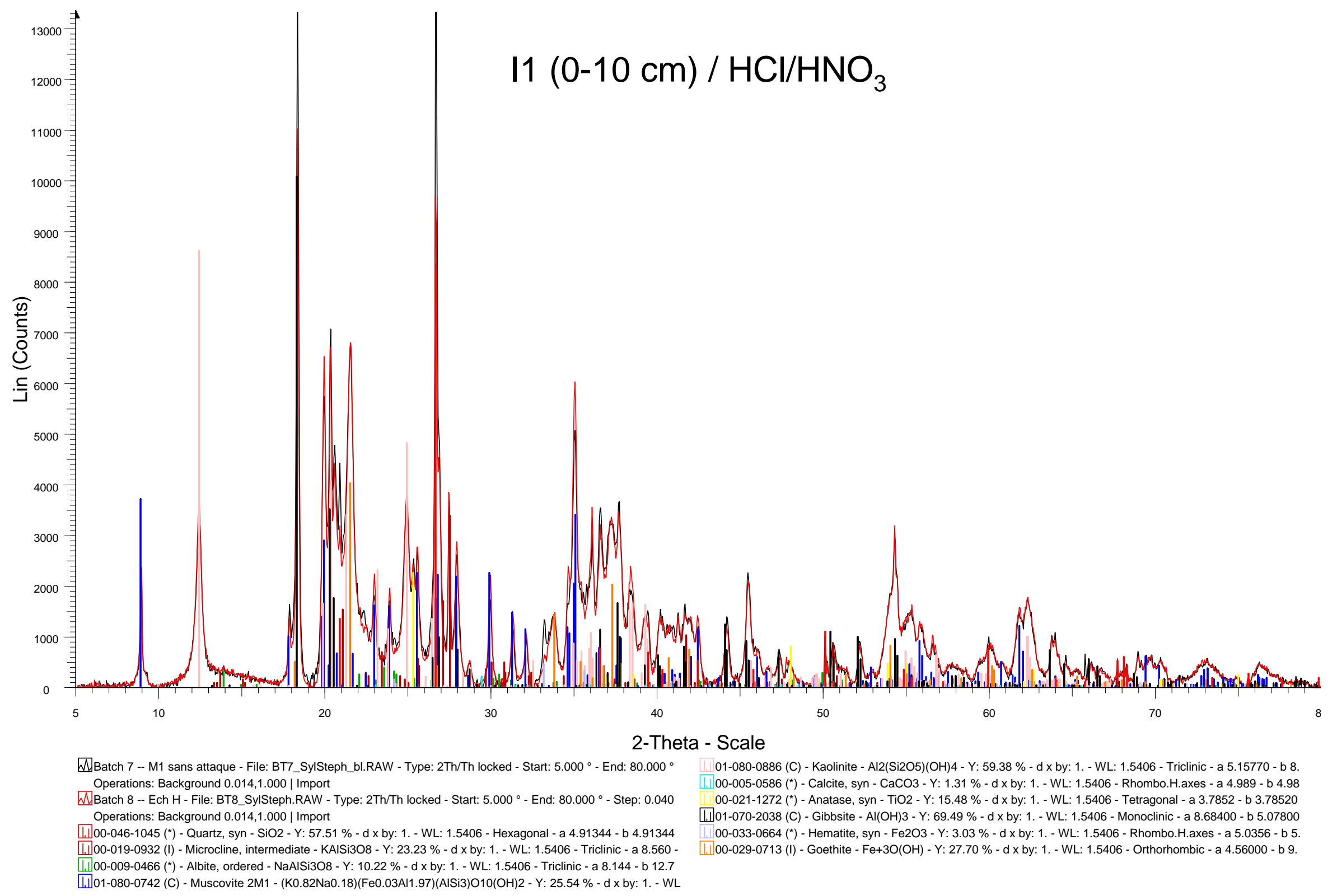


Fig. E4. X-ray diffraction pattern of nodules from sample I-1(180-200m) (black trace) showing identified minerals (colored ticks)

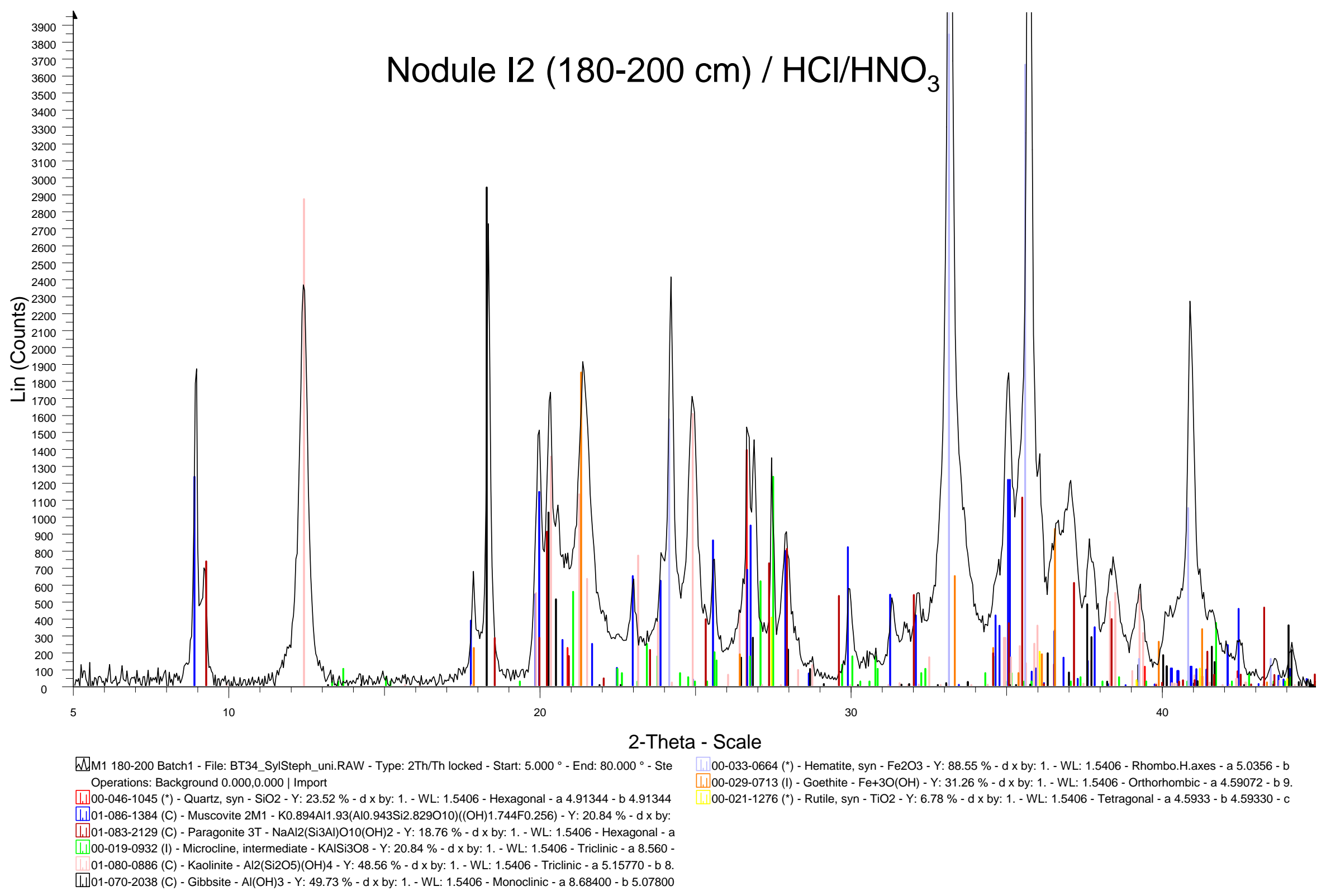


Fig. E5.

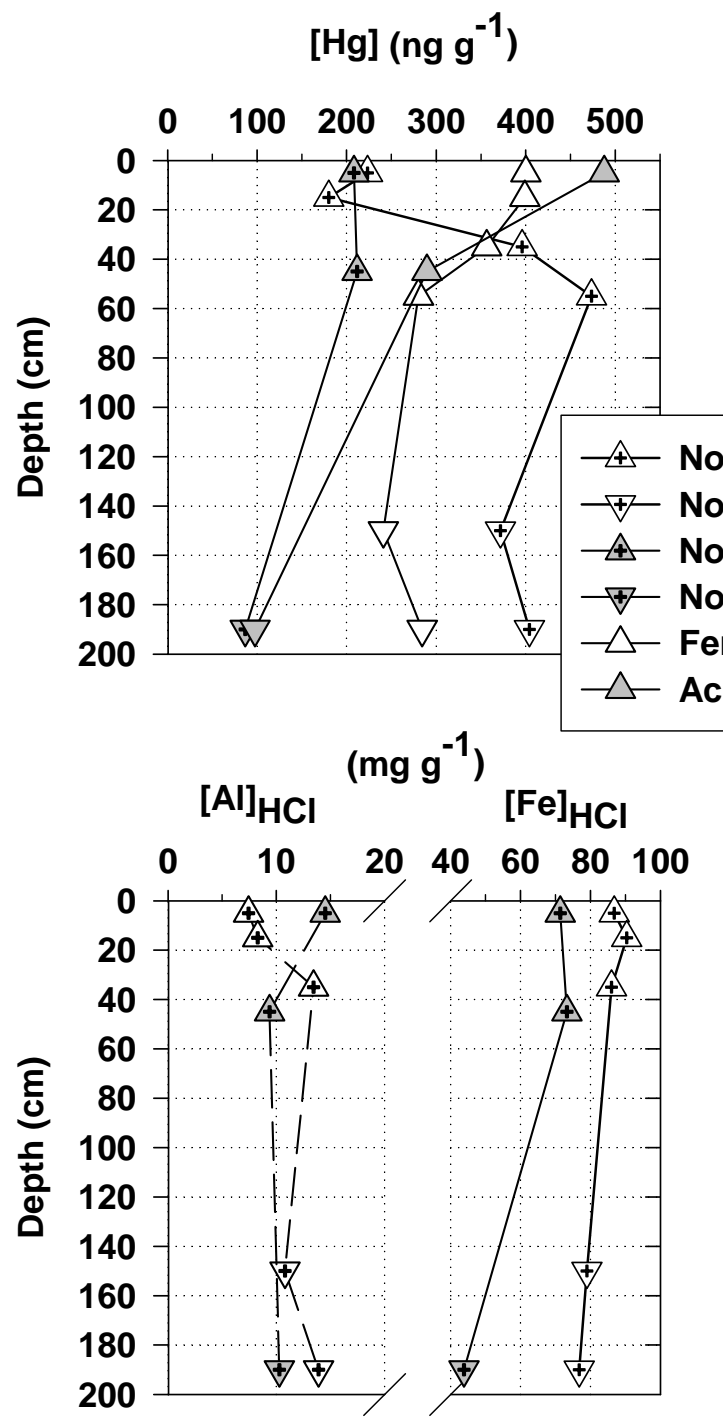

$(\mathrm{Hg})_{\mathrm{HCl}}$ Extraction Yield (\%)
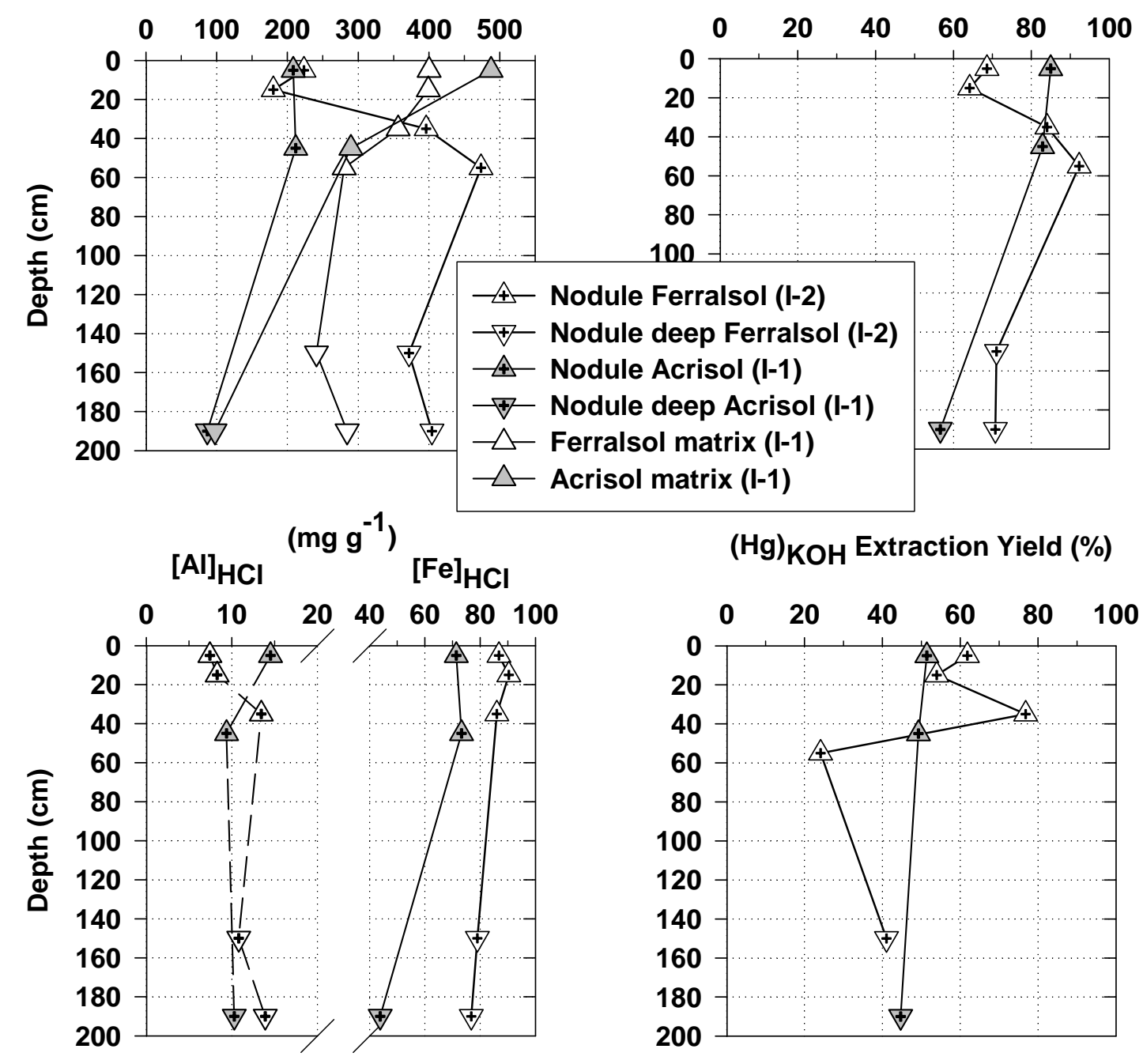